\title{
31. RADIOLARIA FROM THE NORWEGIAN SEA, LEG 38 OF THE DEEP SEA DRILLING PROJECT
}

\author{
Kjell R. Bjфrklund, Geological Institute Department B., University of Bergen, 5014-Bergen-University, Norway
}

\section{INTRODUCTION}

The high latitudes of the Arctic region were first visited by D/V Glomar Challenger in 1974, on Leg 38 of the Deep Sea Drilling Project, to the Norwegian Sea. Seventeen sites were selected, and 17 holes were drilled during this leg (Figure 1, see Table 1 in Chapter 1, this volume)

For radiolarian studies, the Norwegian Sea is a virgin area, as no information is available on either radiolarian stratigraphy or biogeography from pre-Holocene sediments. The distribution of radiolarians in the surface sediments of the Norwegian-Greenland Sea is discussed in only four papers. Stadum and Ling (1969) reported on the recent distribution of phaeodarians and their state of preservation, Petrushevskaya (1969) and Petrushevskaya and Bjфrklund (1974) dealt with the distribution of polycystine radiolarians from surface sediments.

Only one paper, Bjфrklund and Kellogg (1972) deals with the stratigraphy of Tertiary (late Eocene) sediments, from a site located near the top of one of the diapiric structures on the $\mathrm{V} \phi$ ring Plateau southwest of the Lofoten Peninsula. R/V Vema of Lamont-Doherty Geological Observatory has made several cruises (V 23, V27, V 28, and V 30) into the Norwegian-Greenland Sea, taking nearly 200 piston cores. The Tertiary sediments were recovered during the two latter cruises.

Tertiary continental outcrops from northern Europe such as Denmark, North Germany, North Poland, and Franz Josephs Land-Novaja Semlja discussed in Heiberg, 1863; Hustedt (in O. Wetzel, 1935); Schulz, 1927; Grundow, 1884, respectively, are all similar in an absence of radiolarians. However, from other land sections on the USSR eastern territories, radiolarian assemblages of Paleocene and Eocene ages have been described by different Russian authors-Borisenko (1960a, b), Krasheninnikov (1960), Kozlova and Gorbovetz (1966), and Lipman (1950).

DSDP Leg 12 went to the area south of the Norwegian-Greenland Sea, the Labrador Sea, Rockall Basin, and the Bay of Biscay. Here, Benson (1972) reported on radiolarian assemblages with good preservation, recovered from sediments of Pliocene to Oligocene age, while strongly corroded faunas were obtained from Eocene and Paleocene sediments.

Generally no information is available on Tertiary radiolarian stratigraphy in the Norwegian-Greenland Sea. A well-established Quaternary-Tertiary radiolarian stratigraphy has been established by Riedel and Sanfilippo $(1970,1971)$ for DSDP Legs 4 and 7, respectively, and Moore (1971) for Leg 8 in lower Atlantic and Pacific latitudes. During DSDP Leg 12 to the
North Atlantic Ocean, Benson (1972) was able to use the established radiolarian stratigraphy for an age determination of the sediments. Thus, one of the main objectives of this paper was to search out the radiolarian stratigraphy, and see if the already established zonation from lower latitudes could be used with faunal assemblages recovered from the Norwegian Sea.

Based on reports from Russian workers, Lipman (1950), Kozlova and Gorbovetz (1966), and Bjфrklund and Kellogg (1972), the present author recognized similarities in the faunal assemblages from Siberia and the $V \phi$ ring Plateau. Since these faunal assemblages are quite different from the assemblages reported by Benson (1972) and Petrushevskaya and Kozlova (1972), DSDP Legs 12 and 14 from the northern and equatorial Atlantic, respectively, the author concludes that the radiolarian population in the North Atlantic and the Norwegian-Greenland Sea must have somehow been isolated. Most likely this was due to a landbridge, the Iceland-Faeroe Ridge, present during the early phase of the development of the Norwegian-Greenland Sea. Recent data from the Aleutian Islands also lead to the conclusion, that during early Tertiary, the North Pacific was isolated from the Arctic Ocean by a landbridge, due to an elevation of the Aleutian Islands.

The foregoing suggests that the Arctic in the early Tertiary was an isolated ocean, which explains why it is only in the early Tertiary that the Siberian and $V \phi$ ring Plateau faunas have common species.

Goll and Bjфrklund (in press) show that the occurrence of radiolarians in the surface sediment of the Norwegian-Greenland Sea is associated with the high productive areas in the western Norwegian Sea and with the areas in the eastern Norwegian Sea underlying the Norwegian-Atlantic Current (the continuation of the Gulf Stream). The Greenland Sea is barren or very poor in radiolarians. This distribution pattern is not yet fully understood, but the main conclusion must be that the North Atlantic Current passing over the IcelandFaeroe Ridge, into the Norwegian Sea, greatly influences this distribution pattern, together with dissolution and masking effects.

The main objectives of this study were: to try to establish a radiolarian stratigraphy for the NorwegianGreenland Sea; to compare the radiolarian fauna recovered in the North Atlantic during DSDP Legs 12 and 14 with that of Leg 38 , in an attempt to test the hypothesis that the North Atlantic and the Norwegian-Greenland Sea were not connected in the early Tertiary; to search for the time when the North Atlantic Current swept over the Iceland-Faeroe Ridge, in other words, when did the ridge submerge. Finally, could the results of Leg 38 provide information regarding 

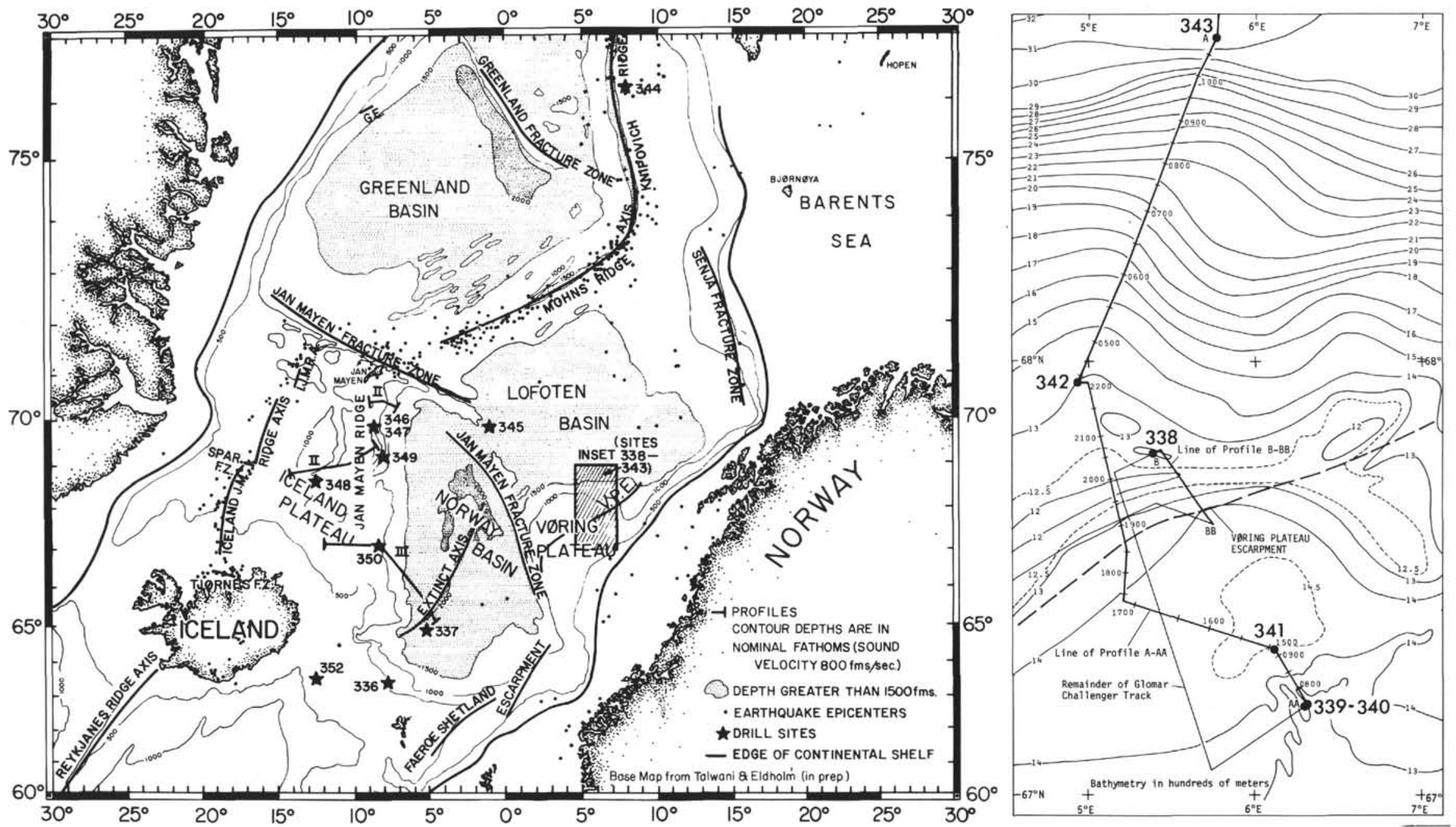

Figure 1. Location of Leg 38 drilling sites, and bathymetry and structure of the Norwegian - Greenland Sea. (Note: Site 351 was occupied but was not drilled. Its location has not been shown on this map. The inset map shows the track of Glomar Challenger between Sites 338 and 343 on the Voring Plateau. Portions between Sites 339 and 343 correspond to line of composite profile illustrated in accompanying diagram. Also shown are position of Voring Plateau Escarpment, and corrected bathymetry of the area, in hundreds of meters, constructed principally from records taken by $R / V$ Vema of Lamont Doherty Geological Observatory, supplemented by Glomar Challenger data. 
climatic shifts during Pleistocene time, and did the Pleistocene coolings have any influence on the current circulation in the North Atlantic?

\section{MATERIAL AND METHODS}

All samples used in this study were cleaned using standard procedures. It is of importance to describe in detail how the samples were processed, because an unknown "microfossil" was frequently found at Sites 338, 344 , and 349 . In the literature, they are described as Anellotubulates. Recently they have been described as being artifacts, produced by reaction of $\mathrm{H}_{2} \mathrm{O}_{2}$ with pyrite (Pickett and Scheibnerova, 1974, and Richardson et al., 1973). Perch-Nielsen (1975) reported on and illustrated similar "microfossils." The procedures were as follows:

1) An equal amount of sediment was used for easier observation of fluctuations in the radiolarians per volume units of sediment.

2) Water was brought to the boiling point in a beaker, sample was introduced, then concentrated $\mathrm{H}_{2} \mathrm{O}_{2}$ and sodium hexametaphosphate (Calgon) was added.

3) The suspension was treated with an ultrasound probe for about 10-15 sec, then sieved on a $44 \mu \mathrm{m}$ screen.

4) Residue was treated with $\mathrm{HCl}$, and the ultrasound probe was used for $5 \mathrm{sec}$.

5) The fine fraction of the residue was brought into suspension in the beaker and decanted.. The suspension was allowed to settle out in a clean beaker, and from this fine fraction the fauna slides were made.

6) $0.5 \mathrm{ml}$ was pipetted out and put on a $25 \times 50 \mathrm{~mm}$ coverslip. Sample was spread out with a toothpick and dried on a hotplate.

7) Caedax $(N=1.56)$ was put on the slide, a drop or two of xylene was put on the coverslip, which was placed on the slide.

8) Slide was allowed to boil for about $30-45 \mathrm{sec}$ to dry out the Caedax.

9) Slide was put on a cold table to get rid of the gas bubbles faster.

The investigations were carried out with a Zeizz Standard RA microscope, normally using the $25 \times$ objective and the $10 \times$ wide-angle ocular. All microphotographs were taken with an automatic Leitz Orthomat camera using the $10 \times$ objective.

Comments on abundances and the state of preservation of radiolarians have to be very subjective, especially the preservation, as this is a mechanism, which is poorly understood and cannot be measured by any instrument.

Three stages of preservation were used:

P: Poor preservation-when the tests were strongly corroded and fragmented;

M: Moderate preservation-when more than $50 \%$ of the tests are fragmented or some corrosion could be observed;

G: Good preservation-when more than $50 \%$ of the tests were unbroken, and no corrosion could be observed.

Five stages of abundances were used:

B: Barren-no radiolarians were found on half the slide;
$\mathrm{R}$ : Rare-one to five fragments were observed on half the slide;

F: Few-more than five fragments or tests were observed on half the slide;

C: Common-mostly complete tests. 1-30 tests per traverse were observed using the $63 \times$ objective;

A: Abundant-mostly complete tests, greater than 30 tests were observed using the $63 \times$ objective.

These designations are only of limited value due to the fact that the faunal slides were made in a semiquantitative way. For this study, about 700 samples were processed and examined for radiolarians.

\section{BIOSTRATIGRAPHY}

During Leg 38, Cenozoic sediments were cored from the Arctic region for the first time, and as similar material never has been available, it was now possible to do a detailed study on Cenozoic radiolarian stratigraphy and paleoecology. Due to time limitations, the major emphasis of the present contribution is to establish a northern high-latitude radiolarian biostratigraphy. It is hoped the biostratigraphic framework outlined in this paper will be useful for the scheduled IPOD Leg 49.

The radiolarian assemblages recovered during this leg had very few species in common with holes drilled further south in the Atlantic Ocean. As no key fossils, upon which the lower latitude Atlantic and Pacific oceans are based, could be found in sufficient numbers, it was necessary to develop a local Norwegian Sea radiolarian stratigraphy. Again, due to time limitations, the taxonomic chapter will only deal with those species being significant for this local biostratigraphy. However, species of little or no value for the stratigraphy, but of value for information on the faunal assemblages, are illustrated.

No absolute or good age determination of the sediment was possible by radiolarians. Therefore, the radiolarian stratigraphy obtained had to be correlated to a time scale by correlation with diatoms (Recentmiddle Miocene) and silicoflagellates (late MioceneEocene), as reported elsewhere in this volume by Schrader, and Martini and Müller, respectively.

Species known to be short ranging in equatorial sediments are usually lacking in Cenozoic radiolarian assemblages from latitudes higher than about $45^{\circ} \mathrm{N}$ in the Atlantic Ocean (compare Benson, 1972). This is most likely due to major changes in the ecological conditions at different latitudes. The recent faunal assemblage in the Norwegian-Greenland Sea surface sediments varies greatly from the assemblage obtained from surface sediments from Rockall Basin. The input of radiolarians transported with the North Atlantic Current are surprisingly low in the Norwegian Sea sediments underlying this major current system. Also, during Neogene time this transportation effect seems to have been negligible. Therefore, the majority of the radiolarians accumulated in the sediments are believed to have been endemic to the Norwegian-Greenland Sea.

\section{Definition of Radiolarian Zones}

Sediments ranging in age from Recent to early (?) Eocene were recovered during Leg 38 . To put together a radiolarian stratigraphy was difficult, as no one site 
contained a continuous sediment column, where radiolarians were present throughout the hole. Thus, to obtain a stratigraphy ranging from Recent to early (?) Eocene, data from various sites had to be compiled. Site 338 turned out to be most important for the establishment of the radiolarian stratigraphy, as this site contained radiolarian-bearing sediments ranging from late Miocene to late (?) Eocene. From this site, 10 radiolarian zones were recognized.

Calocyclas talwanii Zone (Samples 338-29, CC to 27-3, $76-78 \mathrm{~cm})$, Late Eocene CC.

Base: Not defined, radiolarians absent below 29 ,

Top: First appearance of Lophocorys norvegiensis and the extinction of Calocyclas talwanii and Phacodiscus testatus.

General: Lithomitra sp. B and Botryostrobus sp. P (Petrushevskaya and Kozlova, 1972) are present throughout the zone.

Lophocorys norvegiensis Zone (Samples 338-27-3, 76-78 cm to 25, CC), Late Eocene Zone.

Base: Coincident with the top of Calocyclas talwanii

Top: Not well defined, as radiolarians are strongly corroded above $26-3,76-78 \mathrm{~cm}$.

General: Lithomitra sp. B and Botryostrobus sp. P (Petrushevskaya and Kozlova, 1972) are present throughout the zone.

Phorticium sp. A Zone (Samples 338-24-3, 62-64 cm to $21, \mathrm{CC})$, Oligocene

Base: Not well defined, as sediments below 24-3, 62$64 \mathrm{~cm}$ are strongly corroded.

Top: Coincident with the first occurrence of Ceratocyrtis robustus, Actinomma (?) sp. A, and a very characteristic, not identified Nassellaria (only fragments of cephalis and thorax), Nassellaria sp. A.

General: Ceratocyrtis mashae present for the first time in $23-3,72-74 \mathrm{~cm}$.

Ceratocyrtis robustus Zone (Samples 338-21, CC to 19-3, 80-82 cm), Oligocene

Base: Coincident with top of the Phorticium sp. A Zone, and the first occurrence of Ceratocyrtis robustus.

Top: Extinction of Nassellaria sp. A and Spongomelissa sp. Chen, 1975.

Velicucullus oddgurneri Zone (Samples 338-19-3, 80-82 cm to $18, \mathrm{CC}$ ), Oligocene

Base: Coincident with the top of the Ceratocyrtis robustus Zone.

Top: Extinction of Phorticium sp. A and the first occurrence of Gondwanaria japonica and Eucyrtidium sp.

Gondwanaria japonica Zone (Samples 338-18, CC to 13, CC), Early Miocene

Base: Coincident with the top of the Velicucullus oddgurneri Zone.

Top: Extinction of Ceratocyrtis robustus.
Cyrtocapsella eldholmi Zone (Samples 338-13, CC to $12, \mathrm{CC})$, Early Miocene

Base: Coincident with the top of the Gondwanaria japonica Zone.

Top: Extinction of Gondwanaria japonica and the first occurrence of Cyrtocapsella eldholmi, Hexalonche sp. B, Stichocorys biconica, and Heteracantha dentata.

Stichocorys biconica Zone (Samples 338-12, CC to 11-2, $115-117 \mathrm{~cm})$, Early Miocene

Base: Coincident with the top of the Cyrtocapsella eldholmi Zone.

Top: Extinction of Velicucullus oddgurneri.

Actinomma holtedahli Zone (Samples 338-11-2, 115-117 cm to $10-2,146-148 \mathrm{~cm}$ ), Early-middle Miocene

Base: Coincident with the top of the Stichocorys biconica Zone, and the first occurrence of Ceratocyrtis histricosus and Hexalonche sp. A.

Top: Extinction of Stichocorys biconica, Hexalonche sp. B, Actinomma holtedahli, and Cyrtocapsella eldholmi.

Lithomelissa stigi Zone (Samples 338-10-2, 146-148 cm to 8-2, $53-55 \mathrm{~cm}$ ), Middle Miocene

Base: Coincident with the top of the Actinomma holtedahli Zone.

Top: Not well defined, as the sediments above $8-2$, $53-55 \mathrm{~cm}$ have a low radiolarian species diversity and are barren above $7, \mathrm{CC}$.

A radiolarian assemblage from Site 337 of an early (?) Oligocene age was recovered. Lithomitra sp. A was frequently found, and as this species was found in the upper late Eocene, but not in the Oligocene sediments at Site 338 , the Site 337 radiolarian assemblage is believed to be stratigraphically between the two assemblages as reported from Site 338. One radiolarian zone was suggested based on the faunal assemblage recovered.

Lithomitra sp. A Zone (Samples 337-9-3, 20-22 cm to 11, CC) Early (?) Oligocene.

Base: Not defined.

Top: Not defined.

A radiolarian assemblage from Site 339 of a middle (?) Eocene age was recovered. As this site was near the top of a diapir, it is questionable how valuable this site will be for stratigraphic purposes. However, one radiolarian zone was suggested based on the faunal assemblage recovered.

Artostrobus (?) quadriporus Zone (Samples 339-12, CC to 9, CC), Middle Eocene

Base: Not defined.

Top: Not defined.

The oldest radiolarian assemblage recovered during this leg was obtained from Site 343. Here, a radiolarian composition quite different from that at Site 339 was recovered. Compared with the faunal assemblages described in Kozlova and Gorbovetz (1966) from Komissarovo, Well 4-K, and from Ingalinsk, Well 1-K, 
Archnocalpis (?) tumulosa was frequently found in 5 , $\mathrm{CC}$, but was also present in 6, CC. An early Eocene age was based on the recovered silicoflagellate assemblage, and a radiolarian zone is suggested even if the base and top are not defined.

\section{Archnocalpis (?) tumulosa Zone (Samples 343-6, CC to 5, CC), Early Eocene}

Base: Not defined.

Top: Not defined.

Late Miocene, Pliocene, and Pleistocene sediments were recovered from Sites 341 and 348, and it was difficult to put this upper zonation together. In Sample 338-7, CC, there was a high concentration of Hexalonche $\mathrm{sp}$. A. This species was hardly observed in Sample $338-8-2,53-55 \mathrm{~cm}$, the latter believed to be close to the middle-late Miocene boundary. The high occurrence of Hexalonche sp. A is, therefore, believed to be close to the base of the late Miocene. This species was also found in high numbers at Site 341 (Sample 15-2, $30-32 \mathrm{~cm}$ ), and Site 348 (Sample 31-5, 17-19 cm). In those sites Hexalonche sp. A had a very short time range of mass abundancy, and most likely this species had a "bloom" all over the Norwegian Sea in early late Miocene, and may, therefore, serve as a good time marker. Above this Hexalonche sp. A peak at Site 348, a complete sediment column was suggested based on the diatom and silicoflagellate zonations. For Site 348, a radiolarian zonation from late Miocene to Recent could be defined.

\section{Antarctissa whitei Zone, Late Miocene-Pliocene}

Base: Coincident with the first occurrence of Antarctissa whitei.

Top: Extinction (?) of Antarctissa whitei.

Remarks: The Antarctissa whitei Zone overlies an unzoned interval at both Sites 341 and 348. This zone may be extended both upwards and downwards, as sediments above and below are characterized by having a low radiolarian diversity of a moderate to poor preservation. However, Antarctissa whitei has a very robust test, and have most likely survived dissolution. At this stage, the Antarctissa whitei Zone ranges from upper late Miocene to the Pliocene-Pleistocene boundary. The last occurrence of Antarctissa whitei at Site 348 is in Sample 5-5, 147-149 cm, and the PliocenePleistocene boundary based on diatoms has been placed within Core 5. (See Schrader, this volume.)

\section{Cycladophora davisiana Zone, Quaternary}

Base: Coincident with the top of the Antarctissa whitei Zone.

Top: Recent sediments.

Remarks: Generally the "Glacial" sediments recovered during this leg are barren of radiolarians. Only from Sites 336, 341, 348, and 349 were a considerable amount of radiolarians obtained. Cycladophora davisiana was present in all "Glacial" samples containing radiolarians at Site 336, but was only scattered throughout the Pliocene-Pleistocene sediments at Site 348. C. davisiana seems to occur for the first time in the North Atlantic near the base of the Pliocene. This is in agreement with the studies carried out in the Antarctic during Leg 28 (Chen, personal communication). As the range of Antarctissa whitei is not definitely stated, the base of the Cycladophora davisiana Zone may not have been correctly placed. However, at this stage, the base is suggested to be near or closely equal to the PliocenePleistocene boundary.

In summary, a list of the Norwegian Sea radiolarian zones is given in Table 1. The zones are listed from younger towards older.

TABLE 1

Norwegian Sea Radiolarian Zones

Cycladophora davisiana Zone

Antarctissa whitei Zone

Unzoned

Lithomelissa stigi Zone

Actinomma holtedahli Zone

Stichocorys biconica Zone

Cyrtocapsella eldholmi Zone

Gondwanaria japonica Zone

Velicucullus oddgurneri Zone

Ceratocyrtis robustus Zone

Phorticium sp. A

Lithomitra sp. A

Lophocorys norvegiensis Zone

Calocyclas talwanii Zone

Artostrobus (?) quadriporus Zone

Acronocalpis (?) tumidula Zone

\section{SITE DESCRIPTIONS}

In the following section, all sites drilled during Leg 38 will be discussed. Sixteen sites were drilled, but only a few were of stratigraphic importance for establishing a radiolarian zonation for the area. Therefore, range tables will be presented for only the selected sites, and generally only radiolarians of stratigraphic significance are included. Tables listing samples studied, but barren of radiolarians are given for each site.

\section{Iceland-Faeroe Ridge}

Ruddiman and McIntyre (1973) showed that the polar front during the maximum of the last glaciation was situated almost east-west, along $45^{\circ} \mathrm{N}$ latitude. This implies that the surface water circulation in the northern Atlantic during glacial periods was different from the present circulation system. During the last glacial period, the North Atlantic Current did not flow into the Norwegian Sea over the Iceland-Faeroe Ridge, but traveled eastward south of $45^{\circ} \mathrm{N}$ latitude, and turned southward along the Spanish-West African coast. From piston core studies in the Rockall Basin carried out by the author, it was observed that the occurrence of radiolarians fluctuated, being abundant in interglacial, carbonate-rich sediments, and barren in glacial, carbonate-poor sediments. Piston core studies from the Norwegian Sea show that the Recent sediments are relatively rich in radiolarians, but the species diversity is low compared to lower latitudes. It was also observed that, throughout the Norwegian Sea, the radiolarians disappear from the sediments close to the $18 \mathrm{~K}$ level, and have, so far, not been obtained from deeper sediments. The questions which arise are: why are radiolarians absent in earlier interglacials in the Norwegian Sea sediments? Is it because of dissolution, 
masking effect by terrigenous sediments, or lack of production? These complex questions are still not solved, but one of the sites on the Iceland-Faeroe Ridge brought new information on the occurrence of radiolarians in the "glacial" sediments.

\section{Site 336}

In the Pliocene-Pleistocene sediments recovered, radiolarians are present in the interglacial periods, normally of a good preservation in the upper half of the sediments, and moderate to poor in the lower part. Radiolarians are absent in the glacial period sediments.

It has been noted that radiolarians from the Norwegian Sea had been found only in the Holocene sediments, and it was still questionable whether radiolarians were present in earlier interglacial periods. Site 336 showed that at the northern flank of the Iceland-Faeroe Ridge a repetition of radiolarian-rich intervals occurred (compare Table 2). These intervals with high radiolarian content and low input of icerafted material are believed to reflect better ecological conditions during interglacial periods. The species diversity is much lower than in sediments of the same age from the Rockall Basin, indicating that the North Atlantic Current transported very limited amounts of radiolarians from the North Atlantic into the Norwegian Sea. However, it is of interest to observe the high percentage of Cycladophora davisiana $(65 \%$ and $58 \%$ in Samples 1-4, 40-42 $\mathrm{cm}$ and 2-1, 92-94 cm, respectively), while Cycladophora davisiana only makes up $2 \%-3 \%$ in the surface sediments.

Late (?) Oligocene radiolarian-bearing sediments were recovered from 15-1, 33-35 $\mathrm{cm}$ to 19, CC (Figure 2 , Table 3 ). The biogenous silica in this part is generally made up of broken sponge spicules. The radiolarian species diversity is relatively high, with a majority of unidentified Lithomitra spp., Stylodictya spp., and members of the family Spongodiscidae. Velicucullus oddgurneri and Ceratocyrtis mashae were present in Samples 15, CC through 17, CC (see Table 3). Siliceous microfossils are lacking in the sediment column from Samples 20-3, 70-72 $\mathrm{cm}$ to $40, \mathrm{CC}$.

Table 4 lists the Glacial-Recent radiolarian species. No attempt was made to observe the stratigraphic range for all the Recent species. Only those sites having a reasonable amount of species are included in Table 4.

\section{Site 352}

This site was drilled on the southern flank of the Iceland-Faeroe Ridge. Radiolarians from the Pleistocene section (Samples 1-3, 30-32 cm to 3, CC, Table 5, Figure 3 ) were recovered, having a rare abundance, and generally a moderate to poor preservation.

Radiolarians were also present in middle(?)-late Oligocene sediments (Samples 352A-1, CC to 3, CC, Table 5, Figure 3).

In Hole $352 \mathrm{~A}$, radiolarians were not recognized, as the material was very fragmented and strongly corroded. Also at this site, as at 336 , the majority of biogenous silica consisted of broken sponge spicules. One of the main objectives from a paleontological point of view was to compare the faunas on both sides of the
TABLE 2

Pliocene-Pleistocene

Samples Studied for Radiolarians - Site 336

\begin{tabular}{|c|c|c|}
\hline Core & Section & $\begin{array}{l}\text { Interval } \\
(\mathrm{cm})\end{array}$ \\
\hline 1 & 1 & $49-51$ \\
\hline 1 & 1 & $131-133$ \\
\hline 1 & 2 & $35-37^{\mathrm{a}}$ \\
\hline 1 & 2 & $45-47^{\mathrm{a}}$ \\
\hline 1 & 2 & $124-126^{a}$ \\
\hline 1 & 3 & $40-42^{\mathrm{a}}$ \\
\hline 1 & 4 & $40-42^{\mathrm{a}}$ \\
\hline 1 & 5 & $61-63$ \\
\hline 1 & 5 & $131-133$ \\
\hline 1 & & $\mathrm{CC}$ \\
\hline 2 & 1 & $92-94^{\mathrm{a}}$ \\
\hline 2 & 2 & $20-22^{a}$ \\
\hline 2 & 2 & $88-90$ \\
\hline 2 & 3 & $3-5$ \\
\hline 2 & 3 & $84-86$ \\
\hline 2 & 4 & $64-66$ \\
\hline 2 & 4 & $119-121$ \\
\hline 2 & & $\mathrm{CC}$ \\
\hline 3 & 1 & $76-78$ \\
\hline 3 & 1 & $138-140^{\mathrm{a}}$ \\
\hline 3 & 2 & $61-63^{a}$ \\
\hline 3 & & CC \\
\hline 4 & 1 & $133-135$ \\
\hline 4 & 2 & $84-86^{\mathrm{a}}$ \\
\hline 4 & & $\mathrm{CC}^{\mathrm{a}}$ \\
\hline 5 & 1 & $77-79$ \\
\hline 5 & 2 & $63-65$ \\
\hline 5 & 3 & $53-55$ \\
\hline 5 & 4 & $20-22$ \\
\hline 5 & 4 & $125-127$ \\
\hline 5 & 5 & $70-72^{a}$ \\
\hline 5 & 5 & $125-127^{a}$ \\
\hline 5 & 6 & $55-57$ \\
\hline 5 & 6 & $130-132^{a}$ \\
\hline 5 & & $\mathrm{CC}^{\mathrm{a}}$ \\
\hline 6 & 0 & $27-29$ \\
\hline 6 & 1 & $40-42^{\mathrm{a}}$ \\
\hline 6 & 2 & $25-27^{\mathrm{a}}$ \\
\hline 6 & 2 & $145-147^{\mathrm{a}}$ \\
\hline 6 & 3 & $33-35$ \\
\hline 6 & 3 & $135-137$ \\
\hline 6 & 4 & $35-37$ \\
\hline 6 & 4 & $145-147^{a}$ \\
\hline 6 & 5 & $25-27^{\mathrm{a}}$ \\
\hline 6 & 5 & $145-147$ \\
\hline 6 & 6 & $35-37$ \\
\hline 6 & 6 & $135-137$ \\
\hline 6 & & $\mathrm{CC}$ \\
\hline 7 & & $\mathrm{CC}$ \\
\hline 8 & 1 & $25-27^{\mathrm{a}}$ \\
\hline 8 & 1 & $33-35$ \\
\hline 8 & 2 & $35-37^{\mathrm{a}}$ \\
\hline 8 & 2 & $125-137$ \\
\hline 8 & 3 & $20-22$ \\
\hline 8 & 3 & $115-117$ \\
\hline 8 & 4 & $25-27^{\mathrm{a}}$ \\
\hline 8 & 4 & $115-117^{a}$ \\
\hline 8 & 5 & $50-52^{\mathrm{a}}$ \\
\hline 8 & 5 & $130-132^{a}$ \\
\hline 8 & 6 & $20-22^{\mathrm{a}}$ \\
\hline 8 & 6 & $90-92$ \\
\hline 8 & & $\mathrm{CC}^{\mathrm{a}}$ \\
\hline 9 & 1 & $125-127^{\mathrm{a}}$ \\
\hline 9 & 2 & $30-32$ \\
\hline 9 & 2 & $75-77^{\mathrm{a}}$ \\
\hline 9 & 3 & $40-42^{\mathrm{a}}$ \\
\hline
\end{tabular}


TABLE 2 - Continued

\begin{tabular}{ccl}
\hline Core & Section & $\begin{array}{c}\text { Interval } \\
(\mathrm{cm})\end{array}$ \\
\hline 9 & 3 & $75-77^{\mathrm{a}}$ \\
9 & 4 & $10-12$ \\
9 & 4 & $120-122^{\mathrm{a}}$ \\
9 & 5 & $33-35$ \\
9 & 5 & $135-137$ \\
9 & & CC \\
10 & 1 & $75-77^{\mathrm{a}}$ \\
10 & 1 & $135-137$ \\
10 & 2 & $32-34^{\mathrm{a}}$ \\
10 & 2 & $115-117$ \\
10 & & $C C^{\mathrm{a}}$ \\
11 & 1 & $125-127^{\mathrm{a}}$ \\
11 & 2 & $25-27^{\mathrm{a}}$ \\
11 & 2 & $105-107^{\mathrm{a}}$ \\
11 & 3 & $30-32^{\mathrm{a}}$ \\
11 & 3 & $110-112^{\mathrm{a}}$ \\
11 & 4 & $30-32$ \\
11 & & $C C^{\mathrm{a}}$ \\
12 & 1 & $75-77$ \\
12 & 2 & $55-57$ \\
12 & 2 & $141-143$ \\
12 & & $C C$ \\
13 & & CC \\
\hline a & & \\
& &
\end{tabular}

Iceland-Faeroe Ridge. This was, however, impossible as good radiolarian faunas did not exist.

\section{Conclusion}

On both the Atlantic Ocean and the Norwegian Sea sides of the Iceland-Faeroe Ridge, Pliocene-Pleistocene sediments directly overlie sediments of an Oligocene age, more precisely, middle Oligocene in Hole $352 \mathrm{~A}$.

As the path of the North Atlantic Current was strongly influenced by the climate during PliocenePleistocene time, the evolution of this current system must also have been strongly affected by the evolution of the Iceland-Faeroe Ridge. The question arises as to when, during Paleogene time, did the North Atlantic Current sweep into the Norwegian Sea, (i.e., when did the ridge submerge?).

Additional information on this problem is given by the radiolarian species Velicucullus oddgurneri. Material from Leg 12, Site 116 was received from Dr. R.N. Benson and from the core library at LamontDoherty Geological Observatory. By using the data presented by Benson (1972), the radiolarian preservation was observed to be poor during the Oligocene.

Velicucullus oddgurneri is present at both Sites 336 and 338 from the upper part of late Oligocene, is absent at Site 352 [352A], but is present at Site $116(\operatorname{Leg~12})$, Samples $18, \mathrm{CC}$ through $12, \mathrm{CC}$, ranging from the late Oligocene-early Miocene boundary to somewhere in the middle of early Miocene. Using the stratigraphy presented by Benson (1972), it was found that the first occurrence of V.oddgurneri at Site 116 is in Sample 18, $\mathrm{CC}$, which is in the late Miocene, but close to the Oligocene-Miocene boundary.

However, since the time for the first occurrence at Sites 338 and 116 is nearly the same, $V$. oddgurneri cannot be considered endemic to the Norwegian Sea, as it

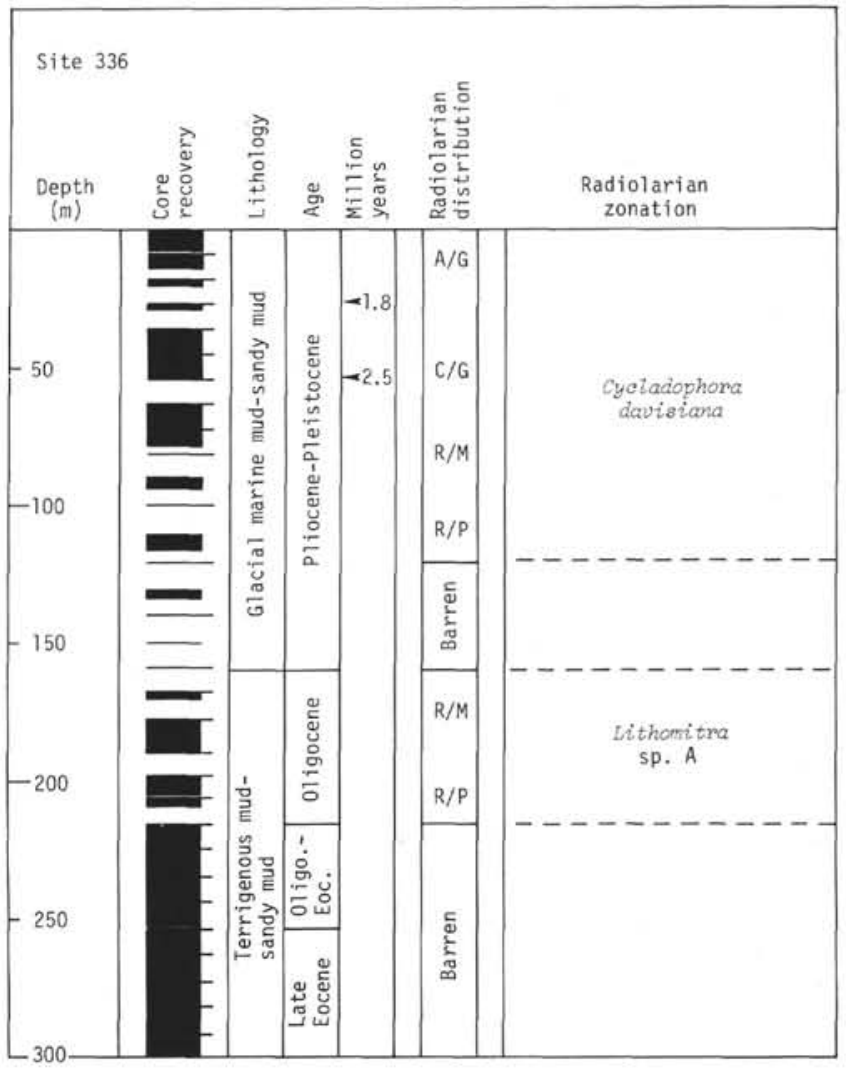

Figure 2. Site summary - Site 336.

is also present at Site 116. It is possible that $V$. oddgurneri was present first in the Norwegian Sea, and then migrated south. However, this is not likely as the Iceland-Faeroe Ridge at this time must have been very shallow. Only the North Atlantic Current may have passed over the ridge, as the production of Arctic Bottom Water had not been initiated at this time. However, the conclusion is the same, namely, that during the upper late Oligocene and lower early Miocene, there must have been sorıe kind of water exchange between the North Atlantic and the Norwegian Sea.

\section{Norway Basin}

\section{Site 337}

This site is located on what are believed to be rift mountains, just east of the "extinct" spreading axis in the Norway Basin. Twenty-eight meters of Pleistocene sediments were recovered, having rare radiolarian occurrences with a moderate preservation (Figure 4, Table 6).

Early-middle Oligocene radiolarian-bearing sediment-was obtained from Samples 9-3, 20-22 cm to 11, $\mathrm{CC}$, however, the species diversity was low, with radiolarians moderately to poorly preserved. Lithomitra sp. A was observed frequently, and as this species is also found in the late Eocene at Site 338, the recovered Oligocene at Site 337 is believed to be stratigraphically above the Eocene sediments, but below the radiolarianbearing Oligocene sediments at Site 338. One radiolarian zone is suggested from this site, Lithomitra sp. A Zone. 
TABLE 3

Pre-Glacial Samples

Studied for

Radiolarians - Site 336

\begin{tabular}{|c|c|c|}
\hline Core & Section & $\begin{array}{c}\text { Interval } \\
(\mathrm{cm})\end{array}$ \\
\hline 15 & 1 & $33-35^{\mathrm{a}}$ \\
\hline 15 & & $\mathrm{CC}^{\mathrm{a}}$ \\
\hline 15 & 3 & $13-15^{\mathrm{a}}$ \\
\hline 16 & & $\mathrm{CC}^{\mathrm{a}}$ \\
\hline 17 & & $\mathrm{CC}^{\mathrm{a}}$ \\
\hline 18 & 3 & $30-32^{\mathrm{a}}$ \\
\hline 18 & & $\mathrm{CC}^{\mathrm{a}}$ \\
\hline 19 & 1 & $130-132^{a}$ \\
\hline 19 & & $\mathrm{CC}^{\mathrm{a}}$ \\
\hline 20 & 3 & $70-72$ \\
\hline 20 & & $\mathrm{CC}$ \\
\hline
\end{tabular}

${ }^{\mathrm{a}}$ Radiolarians observed.

\section{Vóring Plateau}

The $\mathrm{V} \phi$ ring Plateau is a relatively flat (about $1200 \mathrm{~m}$ ) submarine plateau. The plateau is a prominent feature of the continental slope off Norway (Figure 1), and its origin and age have been a subject of considerable speculation. Talwani and Eldholm (1972) described the V $\phi$ ring Plateau Escarpment, which is a buried escarpment with a roughly northeast-southwest trend. This escarpment divides the V $\phi$ ring Plateau in an outer and an inner part. A considerable thickness of sediments, perhaps up to $8 \mathrm{~km}$, may extend into the Mesozoic or even Paleozoic.

\section{Outer V $\phi$ ring Plateau}

\section{Site 338}

This site is located on the inner part of the topographic "high," and was the only site having radiolarian-bearing sediments ranging through most of the late Eocene to late Miocene (Figure 5, Table 7). Miocene and Eocene radiolarians are characterized by good preservation and a high species diversity, while in the Oligocene sediments, the species diversity is low, preservation moderate to poor, with an increase in the Trissocyclidae.

The "Glacial" sediments are generally barren in radiolarians, only in Sample 1-1, 0-2 cm was a rich faunal assemblage recovered, the preservation being good. All the rest of the Pliocene-Pleistocene sediments are barren of radiolarians (Table 8). Hexalonche sp. A are abundant in Sample 7, CC, being absent above and rare below this sample. This peak of Hexalonche sp. A, based on silicoflagellates, occurs in the late Miocene, but close to the middle-late Miocene boundary. Very few species being key fossils for the lower latitude radiolarian stratigraphy were observed. Stichocorys diploconus, Cyrtocapsella tetrapera, and Cannartus violina were found only at a few horizons. One specimen of $C$. violina was observed in Sample 10, CC, while C. tetrapera was found in Sample 17, CC, assumed to be in the lower part of the early Miocene.

The Oligocene sediments (Samples 18-1, 110-112 cm through 24-3, 62-64 cm, Figure 5, Table 8) are
TABLE 4

Radiolarians Separated from Upper "Glacial" Sediments

\begin{tabular}{|c|c|c|c|c|c|}
\hline \multirow[b]{2}{*}{ Spumellaria } & \multicolumn{5}{|c|}{ Sites } \\
\hline & ల్ల & $\stackrel{\infty}{m}$ & 卢 & & के \\
\hline Arachnosphaera dichotoma & & $\mathrm{X}$ & & & $\mathrm{X}$ \\
\hline Cladococcus viminalis & & $\mathrm{X}$ & & $X$ & $\mathrm{X}$ \\
\hline Cromyechinus borealis & $\mathrm{X}$ & $\mathrm{X}$ & $\mathrm{X}$ & $\mathrm{X}$ & $\mathrm{X}$ \\
\hline Drymyomma elegans & & $\mathrm{X}$ & & & $\mathrm{X}$ \\
\hline Echinomma leptodermum & $\mathrm{X}$ & $\mathrm{X}$ & $\mathrm{X}$ & $\mathrm{X}$ & $\mathrm{X}$ \\
\hline Echinomma sp. & $\mathrm{X}$ & $\mathrm{x}$ & $\mathrm{X}$ & $\mathrm{X}$ & $\mathrm{X}$ \\
\hline Hexaconthium enthacanthum & & $\mathrm{X}$ & $\mathrm{X}$ & $\mathrm{X}$ & $\mathrm{X}$ \\
\hline Hexaconthium pachydermum & & $\mathrm{X}$ & & & $\mathrm{X}$ \\
\hline Larcospira minor & & $\mathrm{X}$ & $\mathrm{X}$ & $\mathrm{X}$ & $\mathrm{X}$ \\
\hline Lithelius spiralis & & $\mathrm{x}$ & & & $\mathrm{X}$ \\
\hline Phorticium clevei & $\mathrm{X}$ & $\mathrm{X}$ & $\mathrm{X}$ & $\mathrm{X}$ & $\mathrm{X}$ \\
\hline Rhizoplegma boreale & $\mathrm{X}$ & $\mathrm{X}$ & $\mathrm{X}$ & $\mathrm{X}$ & $\mathrm{X}$ \\
\hline Spongodiscus osculosus & $\mathrm{X}$ & $\mathrm{x}$ & & & $\mathrm{X}$ \\
\hline Spongodiscus resurgens & $\mathrm{x}$ & $\mathrm{x}$ & $\mathrm{X}$ & $\mathrm{X}$ & $\mathrm{X}$ \\
\hline Spongotrochus glacialis & $\mathrm{x}$ & & $\mathrm{X}$ & $\mathrm{X}$ & $\mathrm{X}$ \\
\hline Streblacantha circumtexta & $\mathrm{X}$ & $\mathrm{X}$ & $\mathrm{X}$ & $\mathrm{X}$ & $\mathrm{X}$ \\
\hline Stylodictya tenuispina & & $\mathrm{x}$ & & & $\mathrm{X}$ \\
\hline Stylodictya validispina & & & & & $\mathrm{x}$ \\
\hline \multicolumn{6}{|l|}{ Nassellaria } \\
\hline Amphimelissa setosa & $\mathrm{x}$ & $\mathrm{x}$ & $\mathrm{X}$ & $\mathrm{X}$ & $\mathrm{X}$ \\
\hline Androcyclas gamphonycha & & $\mathrm{x}$ & & & $\mathrm{X}$ \\
\hline Artostrobus annulatus & $\mathrm{x}$ & $\mathrm{x}$ & $\mathrm{X}$ & $\mathrm{X}$ & $\mathrm{X}$ \\
\hline Artostrobus joergenseni & $\mathrm{X}$ & & $\mathrm{X}$ & $\mathrm{X}$ & $\mathrm{X}$ \\
\hline Botryostrobus plathycephalus & & & $\mathrm{X}$ & $\mathrm{X}$ & $\mathrm{X}$ \\
\hline Botryostrobus tumidulus & $\mathrm{X}$ & & & & \\
\hline Campylacantha cladophora & & & & & $\mathrm{X}$ \\
\hline Ceratocyrtis glaeus & & & $\mathrm{X}$ & $\mathrm{X}$ & $\mathrm{X}$ \\
\hline Ceratocyrtis histricosus & & & $\mathrm{x}$ & $\mathrm{X}$ & $\mathrm{X}$ \\
\hline Ceratospyris hyperboreus & & & & & $\mathrm{X}$ \\
\hline Cladoscenium tricolpium & & $\mathrm{X}$ & & & $\mathrm{X}$ \\
\hline Corocalyptra craspedota & & & $\mathrm{X}$ & & $\mathrm{X}$ \\
\hline Cornutella profunda & $\mathrm{X}$ & $\mathrm{x}$ & & & $\mathrm{X}$ \\
\hline Cycladophora davisiana & $\mathrm{X}$ & $\mathrm{x}$ & $\mathrm{X}$ & $\mathrm{x}$ & $\mathrm{X}$ \\
\hline Dictyoceras acanthicum & & $\mathrm{x}$ & & & \\
\hline Euscenium (?) corynephorum & & & & $\mathrm{X}$ & $\mathrm{X}$ \\
\hline Gonosphaera primordialis. & & $\mathrm{X}$ & & & $\mathrm{X}$ \\
\hline Litharachnium tentorium & $\mathrm{X}$ & $\mathrm{x}$ & & & \\
\hline Lithostrobus cuspidatus & $\mathrm{X}$ & & & $\mathrm{X}$ & \\
\hline Lithomelissa hystrix & & $\mathrm{x}$ & & & $\mathrm{X}$ \\
\hline Lithomelissa setosa & $\mathrm{X}$ & $\mathrm{x}$ & $\mathrm{X}$ & $\mathrm{x}$ & $\mathrm{X}$ \\
\hline Lithomitra arachnea & $\mathrm{X}$ & & & & \\
\hline Lithomitra lineata & $\mathrm{X}$ & & $\mathrm{X}$ & $\mathrm{X}$ & $\mathrm{X}$ \\
\hline Peridium longispinum & & & $\mathrm{x}$ & $\mathrm{X}$ & $\mathrm{X}$ \\
\hline Phormacantha hystrix & & $\mathrm{x}$ & & & $\mathrm{X}$ \\
\hline Plagiacantha arachnoides & $\mathrm{X}$ & & $\mathrm{X}$ & $\mathrm{x}$ & $\mathrm{X}$ \\
\hline Plectacantha trichoides & & & & & $\mathrm{X}$ \\
\hline Pseudodictyophimus gracilipes & $\mathrm{X}$ & & $\mathrm{X}$ & $\mathrm{X}$ & $\mathrm{X}$ \\
\hline Stichocorys seriatus & & $\mathrm{X}$ & & & $\mathrm{X}$ \\
\hline Theocyrtis borealis & & & $\mathrm{x}$ & $\mathrm{X}$ & $\mathrm{X}$ \\
\hline
\end{tabular}

characterized by a relatively low species diversity and rare to poor preservation in the lower part. Phorticium sp. A is characteristic for the Oligocene sediments.

Eocene radiolarian-bearing sediments (Samples 26-3, $62-64 \mathrm{~cm}$, through $29, \mathrm{CC}$ ) do have a high species diversity and good preservation. Lophocorys norvegiensis, Calocyclas talwanii, Peripyramus magnifica, Lithomitra 
TABLE 5

Pliocene-Pleistocene

Samples Studied for

Radiolarians - Site 352

Core Section Interval

Hole 352

$\begin{array}{ll}1 & \mathrm{CC} \\ 2 & \mathrm{CC} \\ 4 & \mathrm{CC} \\ 5 & \mathrm{CC}\end{array}$

Hole 352A

\begin{tabular}{ll}
1 & $\mathrm{CC}$ \\
2 & $\mathrm{CC}$ \\
3 & $\mathrm{CC}$ \\
\hline
\end{tabular}

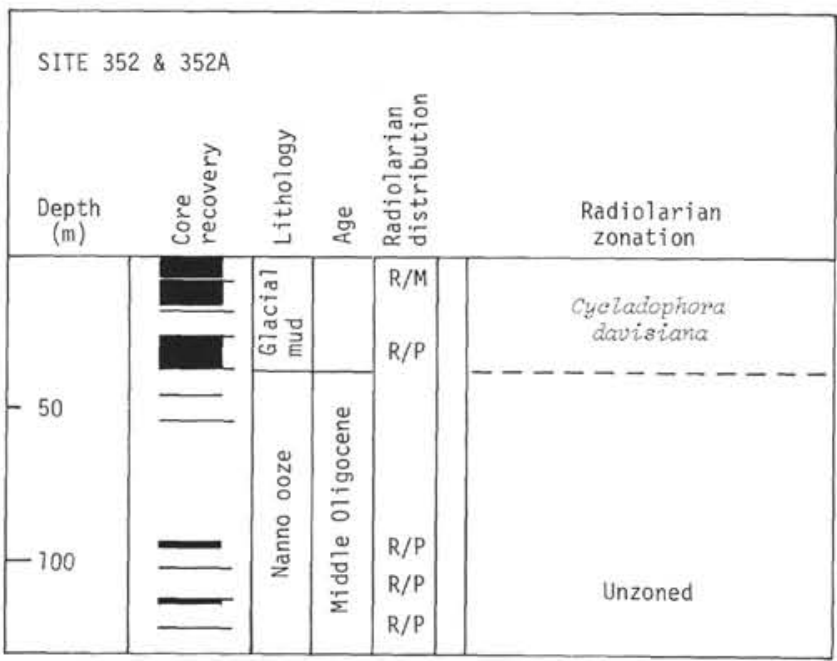

Figure 3. Site summary - Site 352, Holes 352 and $352 \mathrm{~A}$.

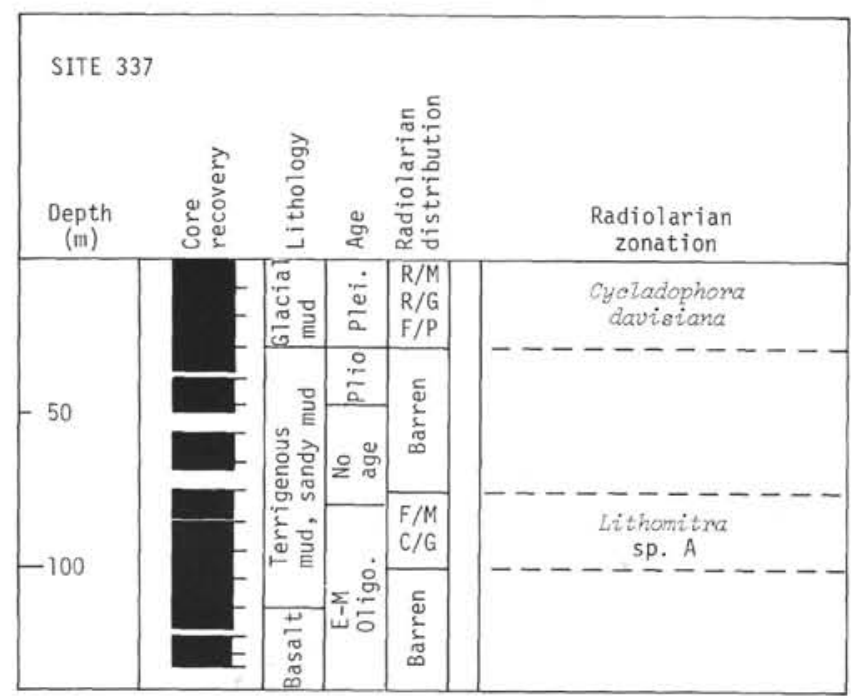

Figure 4. Site summary - Site 337.

sp. A, and Botryostrobus joides are characteristic species. Older Eocene sediments are barren of siliceous microfossils (Table 9). Ten radiolarian zones were suggested for this site (Figure 5).
TABLE 6

Samples Studied for

Radiolarians - Site 337

\begin{tabular}{|c|c|c|}
\hline Core & Section & $\begin{array}{l}\text { Interval } \\
(\mathrm{cm})\end{array}$ \\
\hline 1 & 3 & $30-32^{a}$ \\
\hline 1 & & $\mathrm{CC}^{\mathrm{a}}$ \\
\hline 2 & 3 & $100-102^{\mathrm{a}}$ \\
\hline 2 & & $\mathrm{CC}^{\mathrm{a}}$ \\
\hline 3 & 3 & $110-112^{a}$ \\
\hline 3 & & \\
\hline 4 & 3 & $40-42$ \\
\hline 4 & & $\mathrm{CC}$ \\
\hline 5 & 3 & $80-82$ \\
\hline 5 & & $\mathrm{CC}$ \\
\hline 6 & 2 & $65-67$ \\
\hline 6 & & $\mathrm{CC}$ \\
\hline 7 & 3 & $83-85$ \\
\hline 7 & & $\mathrm{CC}$ \\
\hline 8 & 2 & $20-22$ \\
\hline 8 & & $\mathrm{CC}$ \\
\hline 9 & 3 & $20-22^{\mathrm{a}}$ \\
\hline 9 & & $\mathrm{CC}^{\mathrm{a}}$ \\
\hline 10 & 3 & $20-22^{a}$ \\
\hline 10 & & $C C^{\mathrm{a}}$ \\
\hline 11 & 3 & $25-27^{\mathrm{a}}$ \\
\hline 11 & & $\mathrm{CC}^{\mathrm{a}}$ \\
\hline 12 & 3 & $20-22$ \\
\hline 12 & & CC \\
\hline
\end{tabular}

Site 342

This site is located on the outer part of the topographic "high," and only early Miocene sediments had considerable amounts of radiolarians of a good preservation (Figure 6, Table 10). Cyrtocapsella tetrapera (Plate 17, Figures 19, 20) occurred in relatively high numbers in Sample 3, CC, correlated to Site 338 with an upper early Miocene age.

C. tetrapera are not common in the Norwegian Sea sediments, but were reported by Benson (1972) as abundant in upper early Miocene at Site 116, Leg 12. It is worth mentioning that the occurrence of $C$. tetrapera in the Norwegian Sea most likely is a result of transportation by the North Atlantic Current, and is, therefore, taken as evidence for a definite submergence of the Iceland-Faeroe Ridge during the upper late Miocene.

Velicucullus oddgurneri was observed in Sample 6, CC. Basement (?) was recovered directly under these early Miocene sediments, while early Eocene sediments were recovered at Site 338. Both sites are on the same topographic "high," and the difference in age between the two sites may be due to either: (1) that basement is a basalt sill, or (2) that Site 342 had a more effective submarine erosion than Site 338. Two zones, defined at Site 338, were recognized at Site 342 (Figure $6)$.

\section{Site 343}

This site is located at the eastern margin of the Lofoten Basin, at the foot of the V $\phi$ ring Plateau, and this site yielded the oldest sediments, early Eocene. The sediment is generally terrigenous, and biogenic silica was observed, having a good preservation, only in Samples 5-3, 55-57 cm through 6, CC. However, some 


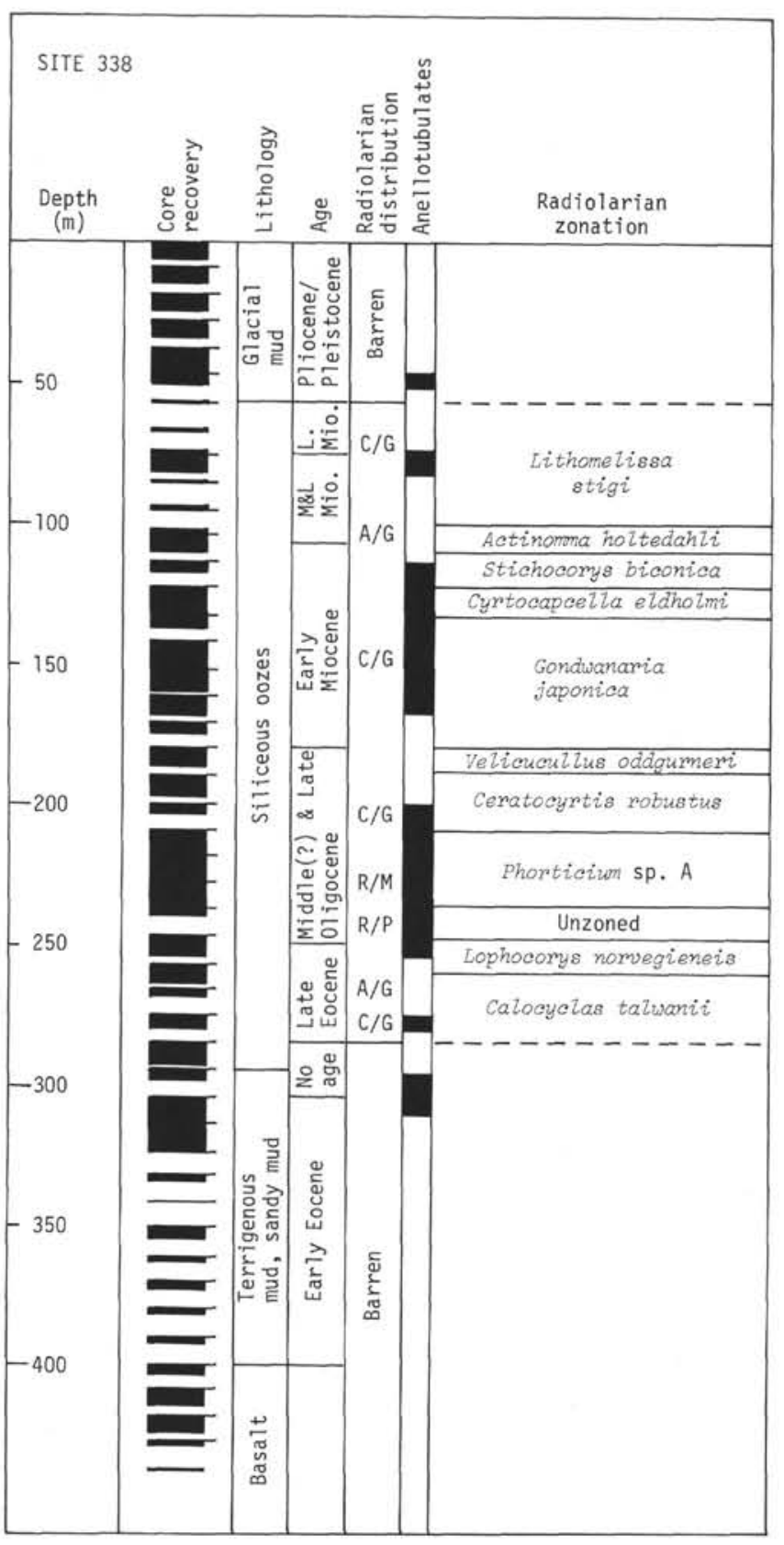

Figure 5. Site summary - Site 338.

strongly corroded fragments were found in Samples 12, $\mathrm{CC}$ and 13, CC (Figure 7, Table 11). Sediments younger than early Eocene, but older than the "Glacial" are absent, most likely due to submarine erosion.

\section{Conclusion, Outer V $\phi$ ring Plateau}

The best site for biostratigraphic purposes turned out to be Site 338. Radiolarian-bearing sediments were present from late Eocene to lower late Miocene. The Norwegian Sea radiolarian stratigraphy is basically compiled from Site 338, with additional information from a few other sites.

Cyrtocapsella tetrapera in the Norwegian Sea sediments is taken as evidence for a definite submergence of the Iceland-Faeroe Ridge during late early Miocene, as $C$. tetrapera is understood as being
TABLE 7

Pliocene-Pleistocene Samples Studied for Radiolarians - Site 338

\begin{tabular}{|c|c|c|}
\hline Core & Section & Interval $(\mathrm{cm})$ \\
\hline 1 & 1 & $0-2^{\mathrm{a}}$ \\
\hline 1 & 1 & $84-86$ \\
\hline 1 & 1 & $127-129$ \\
\hline 1 & 1 & $136-138$ \\
\hline 1 & 1 & $143-145$ \\
\hline 1 & 2 & $80-82$ \\
\hline 1 & 2 & $110-112$ \\
\hline 1 & 2 & $130-132$ \\
\hline 1 & 2 & $141-143$ \\
\hline 1 & 3 & $23-25$ \\
\hline 1 & 3 & $69-71$ \\
\hline 1 & 3 & $118-120$ \\
\hline 1 & 4 & $45-47$ \\
\hline 1 & 4 & $93-95$ \\
\hline 1 & 4 & $126-128$ \\
\hline 1 & & CC \\
\hline 2 & 1 & $77-79$ \\
\hline 2 & 1 & $121-123$ \\
\hline 2 & 2 & $70-72$ \\
\hline 2 & 2 & $127-129$ \\
\hline 2 & 3 & $43-45$ \\
\hline 2 & 3 & $133-135$ \\
\hline 2 & 4 & $10-12$ \\
\hline 2 & 4 & $77-79$ \\
\hline 2 & & $\mathrm{CC}$ \\
\hline 3 & 2 & $52-54$ \\
\hline 3 & 2 & $122-124$ \\
\hline 3 & 3 & $132-134$ \\
\hline 3 & 3 & $136-138$ \\
\hline 3 & 4 & $17-19$ \\
\hline 3 & 4 & $35-37$ \\
\hline 3 & 4 & $102-104$ \\
\hline 3 & 4 & $130-132$ \\
\hline 3 & & CC \\
\hline 4 & 1 & $116-118$ \\
\hline 4 & 2 & $35-37$ \\
\hline 4 & 2 & $116-118$ \\
\hline 4 & 3 & $96-98$ \\
\hline 4 & 4 & $29-31$ \\
\hline 4 & 4 & $108-110$ \\
\hline 4 & & CC \\
\hline 5 & 2 & $53-55$ \\
\hline 5 & 3 & $76-78$ \\
\hline 5 & 3 & $135-137$ \\
\hline 5 & 4 & $81-83$ \\
\hline 5 & 5 & $10-12$ \\
\hline 5 & 5 & $78-80$ \\
\hline 5 & 6 & $30-32$ \\
\hline 5 & 6 & $120-122$ \\
\hline 5 & & $\mathrm{CC}$ \\
\hline
\end{tabular}

${ }^{a}$ Radiolarians observed.

transported from the Atlantic by the North Atlantic Current. Substantial submarine erosion is believed to have taken place at Sites 342 and 343.

\section{Inner V $\phi$ ring Plateau}

This part of the plateau is located on the landward side of the V $\phi$ ring Plateau Escarpment. Basement was not noted on seismic profiles, and the sediment thickness is assumed to be as much as $8 \mathrm{~km}$. It was in these sediments that the prime biostratigraphic site was to be drilled.

Closer to land, the plateau has a very "mountainous" appearance due to a number of diapiric structures. These were drilled in an attempt to find sediments older 
TABLE 8

Radiolarian Species Distribution, Abundance and Preservation - Site 338

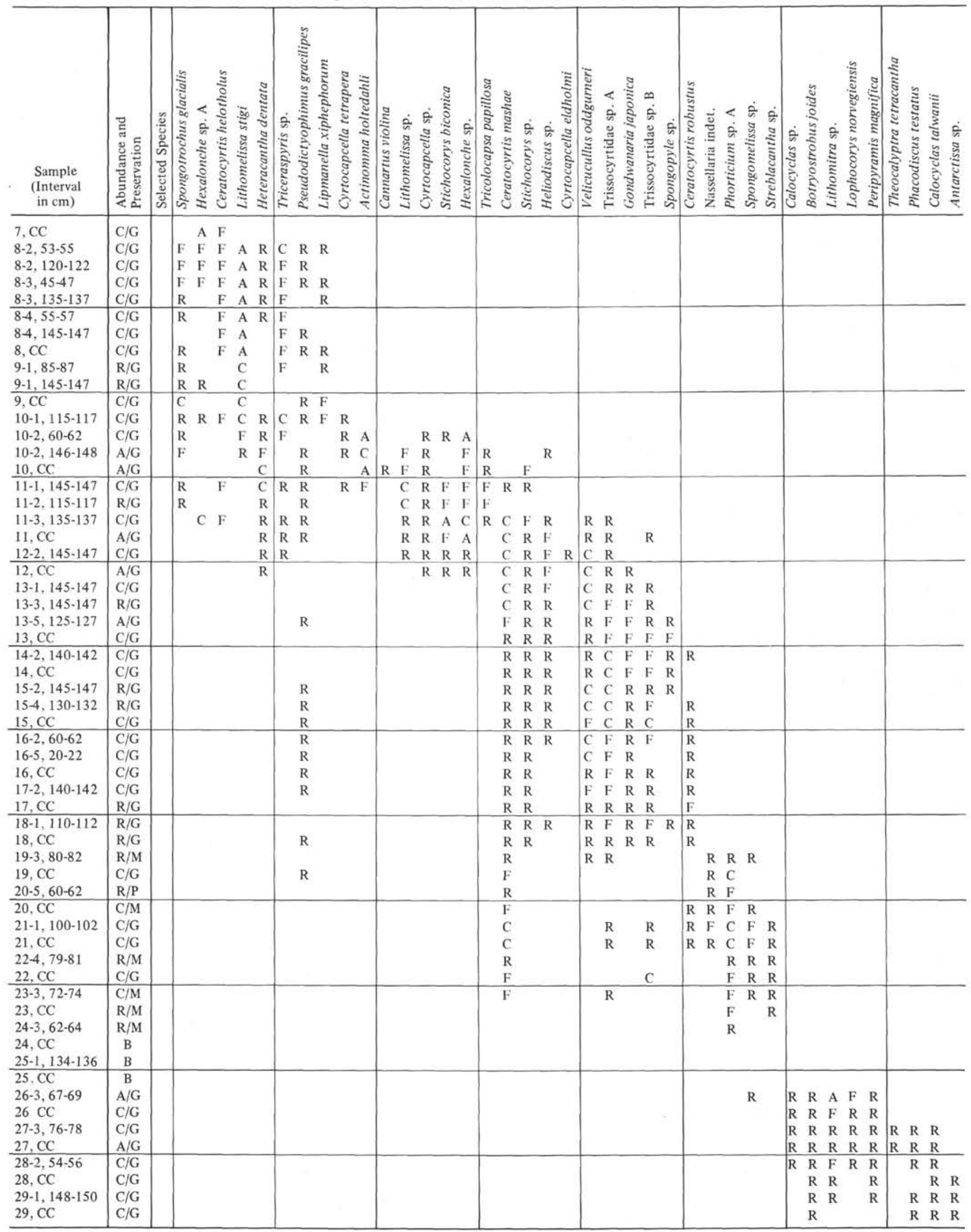


TABLE 9

Pre-Glacial Age Samples Barren of Radiolarians-Site 330

\begin{tabular}{|c|c|c|}
\hline Core & Section & Interval $(\mathrm{cm})$ \\
\hline 30 & 2 & $42-44$ \\
\hline 30 & 4 & $129-131$ \\
\hline 30 & & CC \\
\hline 31 & 1 & $89-91$ \\
\hline 31 & 2 & $97-99$ \\
\hline 31 & & $\mathrm{CC}$ \\
\hline
\end{tabular}

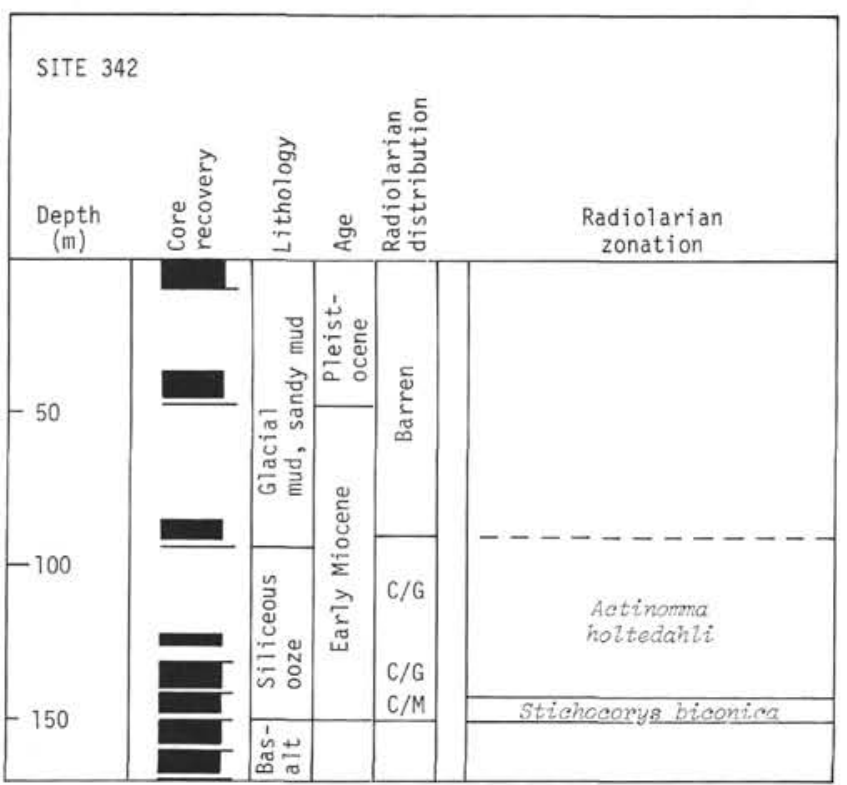

Figure 6. Site summary - Site 342.

TABLE 10

Samples Studied for Radiolarians - Site 342

\begin{tabular}{ccl}
\hline Core & Section & $\begin{array}{c}\text { Interval } \\
(\mathrm{cm})\end{array}$ \\
\hline 1 & & $\mathrm{CC}$ \\
2 & & $\mathrm{CC}$ \\
3 & 2 & $50-52^{\mathrm{a}}$ \\
3 & & $\mathrm{CC}^{\mathrm{a}}$ \\
4 & 2 & $115-117^{\mathrm{a}}$ \\
4 & & $\mathrm{CC}^{\mathrm{a}}$ \\
5 & 2 & $125-127^{\mathrm{a}}$ \\
5 & & $\mathrm{CC}^{\mathrm{a}}$ \\
6 & 3 & $130-132^{\mathrm{a}}$ \\
6 & & $\mathrm{CC}^{\mathrm{a}}$ \\
\hline $\mathrm{a}^{\mathrm{a}}$ & &
\end{tabular}

than reported by Bjфrklund and Kellogg (1972) from the same area.

\section{Site 339}

This site was located on one of the diapirs. Roughly 75 meters of Pliocene-Pleistocene sediments, mostly barren in radiolarians, was recovered, overlying middle Eocene radiolarian-bearing sediments. Phacodiscus

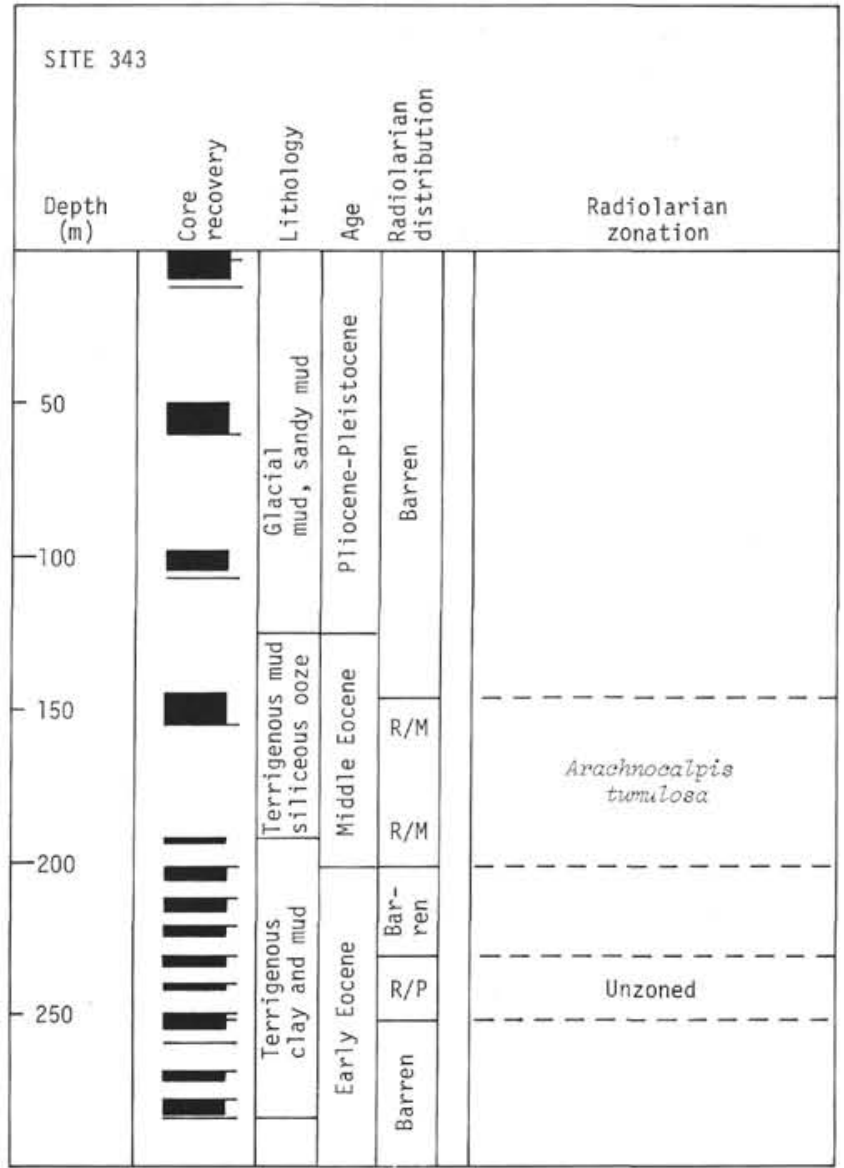

Figure 7. Site summary - Site 343.

testatus, Cornutella californica (?), Peripyramis magnifica, Spongopyle spiralis, Lophocorys norvegiansis were observed in these middle Eocene sediments (Figure 8, Table 12). All samples, except Core 1, have a well-preserved radiolarian fauna, and the species diversity is high. The sediments are strongly disturbed, most likely by a combination of diapirism and drilling.

\section{Site 340}

This site is also located on the diapir, but on a topographically steeper part. The Pliocene-Pleistocene sediments, about 10 meters, were nearly barren of radiolarians, but the underlying late Eocene sediments, all contained radiolarians of a good preservation (Figure 9, Table 13). The species diversity is high with Calocyclas talwanii, Cornutella californica, Peripyramis magnifica, Theocalyptra tetracantha, Stylodictya variabilis, Spongopyle spiralis, and Lophocorys norvegiensis as the dominating species. This site shows a reversed (?) stratigraphy and the sediment is greatly disturbed, perhaps a result of diapirism and coring. This site should not be used for stratigraphic purposes.

\section{Site 341}

This site is located northwest of the diapir sites, but southeast of Site 338. The site was drilled in an area of flat-lying beds, and the objective was to obtain a Tertiary biostratigraphy of the Norwegian continental 
TABLE 11

Samples Studied for

Radiolarians - Site 343

\begin{tabular}{rcl}
\hline Core & Section & $\begin{array}{c}\text { Interval } \\
(\mathrm{cm})\end{array}$ \\
\hline 1 & 2 & $47-49$ \\
1 & & $\mathrm{CC}$ \\
2 & 3 & $66-68$ \\
2 & & $\mathrm{CC}$ \\
3 & 3 & $80-82$ \\
3 & & $\mathrm{CC}$ \\
4 & 2 & $53-55$ \\
4 & & $\mathrm{CC}$ \\
5 & 3 & $55-57^{\mathrm{a}}$ \\
5 & & $\mathrm{CC}$ \\
6 & 1 & $145-147^{\mathrm{a}}$ \\
6 & & $\mathrm{CC}$ \\
7 & 3 & $35-37$ \\
7 & & $\mathrm{CC}$ \\
8 & 2 & $60-62$ \\
8 & & $\mathrm{CC}$ \\
9 & 2 & $45-47$ \\
9 & & $C C$ \\
10 & 2 & $55-57$ \\
10 & & $\mathrm{CC}$ \\
11 & 2 & $60-62$ \\
11 & & $C C$ \\
12 & 2 & $80-82$ \\
12 & & $C C^{\mathrm{a}}$ \\
13 & & $\mathrm{CC}$ \\
14 & & $C C$ \\
15 & 2 & $80-82$ \\
15 & & $\mathrm{CC}$ \\
\hline
\end{tabular}

${ }^{a}$ Occurrence of early Eocene radiolarians.

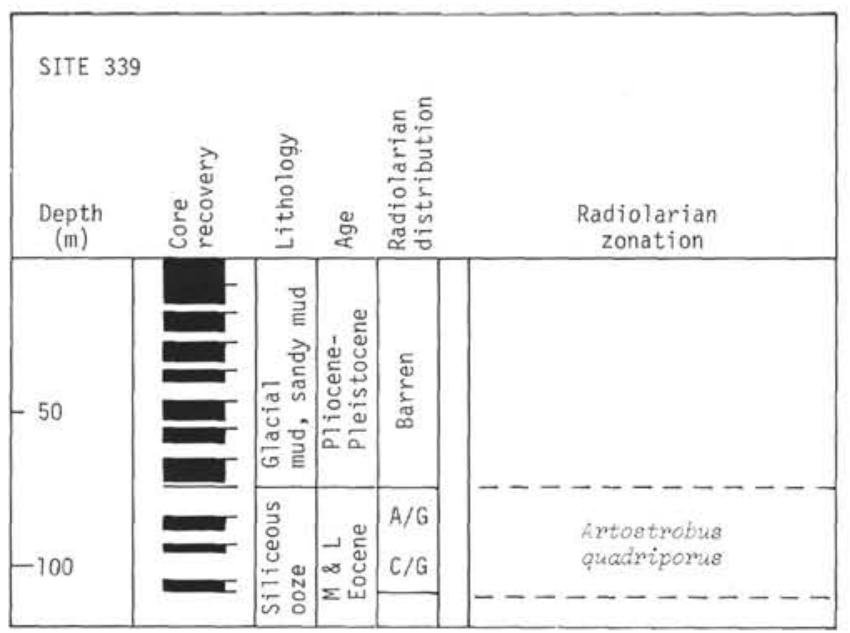

Figure 8. Site summary - Site 339.

margin. The hole drilled through a Pliocene-Pleistocene section, nearly five times as thick as at Site 338 .

Radiolarians are not generally present in this section. Only in Samples 4-2, 94-96 cm to 7, CC was a reworked radiolarian assemblage of good preservation obtained (Figure 10, Table 14). Velicucullus oddgurneri, Stichocorys biconica, Eucyrtidium sp., and Hexalonche sp. A do indicate an upper middle to late
TABLE 12

Pliocene-Pleistocene

Samples Studied for

Radiolarians - Site 339

\begin{tabular}{rcl}
\hline Core & Section & $\begin{array}{c}\text { Interval } \\
(\mathrm{cm})\end{array}$ \\
\hline 1 & 3 & $\begin{array}{l}63-65^{\mathrm{a}} \\
C^{\mathrm{a}}\end{array}$ \\
1 & & $70-72$ \\
2 & 3 & $\mathrm{CC}$ \\
2 & & $90-92$ \\
3 & 3 & $\mathrm{CC}$ \\
3 & & $83-85$ \\
4 & 3 & $\mathrm{CC}$ \\
4 & & $94-96$ \\
5 & 2 & $84-86$ \\
6 & 4 & $C C$ \\
6 & & $79-81$ \\
7 & 3 & $C C$ \\
7 & & $23-25$ \\
8 & 1 & $130-132^{\mathrm{a}}$ \\
8 & 1 & $110-112^{\mathrm{a}}$ \\
8 & 2 & $80-82^{\mathrm{a}}$ \\
8 & 3 & $98-100^{\mathrm{a}}$ \\
8 & 4 & $\mathrm{CC}^{\mathrm{a}}$ \\
8 & & $\mathrm{CC}^{\mathrm{a}}$ \\
9 & & $140-142^{\mathrm{a}}$ \\
10 & 2 & $C^{\mathrm{a}}$ \\
10 & & $117-119^{\mathrm{a}}$ \\
11 & 1 & $C^{\mathrm{a}}$ \\
11 & & $110-112^{\mathrm{a}}$ \\
12 & 2 & \\
\hline
\end{tabular}

${ }^{\mathrm{a}}$ Radiolarians observed.

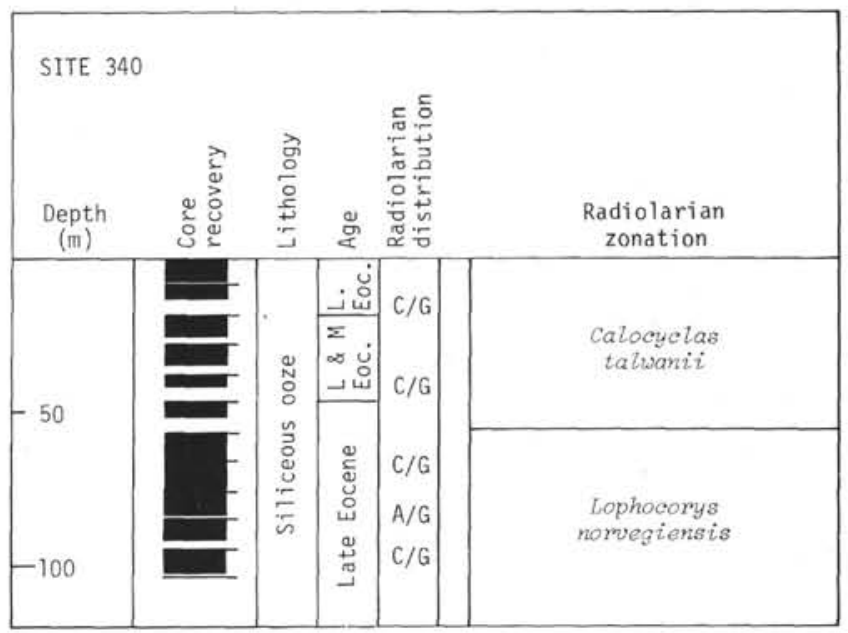

Figure 9. Site summary - Site 340.

Miocene age for these redeposited sediments (Figure 10).

The Pliocene-Pleistocene sequence directly overlying late Miocene sediments has a high radiolarian species diversity, and all siliceous microfossils are of a good preservation (Figure 10, Table 15). Antarctissa whitei, Ceratocyrtis mashae, C. compacta, Heteracantha dentata, Triceraspyris sp., Hexalonche sp. A, Gondwanaria japonica, and Velicucullus oddgurneri were frequently observed. Hexalonche sp. A are abundant in Sample 31$5,17-19 \mathrm{~cm}$, assumed to correspond to Sample 338-7, 
TABLE 13

Late Eocene Samples

Studied for

Radiolarians - Site 340

\begin{tabular}{|c|c|c|}
\hline Core & Section & $\begin{array}{l}\text { Interval } \\
(\mathrm{cm})\end{array}$ \\
\hline 1 & 3 & $85-87$ \\
\hline 1 & & $\mathrm{CC}$ \\
\hline 2 & 3 & $30-32$ \\
\hline 2 & & $\mathrm{CC}$ \\
\hline 3 & 3 & $60-62$ \\
\hline 3 & & $\mathrm{CC}$ \\
\hline 4 & 3 & $35-37$ \\
\hline 4 & & $\mathrm{CC}$ \\
\hline 5 & 2 & $45-47$ \\
\hline 5 & & $\mathrm{CC}$ \\
\hline 6 & 3 & $55-57$ \\
\hline 6 & & $\mathrm{CC}$ \\
\hline 7 & 4 & $130-132$ \\
\hline 7 & & $\mathrm{CC}$ \\
\hline 8 & 3 & $45-47$ \\
\hline 8 & & $\mathrm{CC}$ \\
\hline 9 & 3 & $35-37$ \\
\hline 9 & & $\mathrm{CC}$ \\
\hline 10 & 3 & $45-47$ \\
\hline 10 & & $\mathrm{CC}$ \\
\hline 11 & 3 & $45-47$ \\
\hline 11 & 3 & $\mathrm{CC}$ \\
\hline
\end{tabular}

${ }^{\mathrm{a}}$ All samples contain radiolarians, but show a reversed

(?) stratigraphy.

CC. Two radiolarian zones were suggested from this site.

\section{Conclusion, Inner V $\phi$ ring Plateau}

Sediments from both Sites 339 and 340 are composed of Tertiary biogenous siliceous oozes, which are believed to be the principal material of the diapir cores.

A principal question is what is causing the relatively thick layer of displaced Tertiary material in the Pliocene-Pleistocene section. Since this site is only a short distance northwest of the diapiric area, and the diapir cores are Tertiary biogenous siliceous oozes, it is assumed that this body of displaced Tertiary material represents the time of principal diapirism. As the Pliocene-Pleistocene sediments are without radiolarians they cannot indicate the time for the onset of the diapirism.

\section{Knipovich Ridge}

\section{Site 344}

It was assumed that this site would be of great value from a paleontological point of view, as it was the northernmost site drilled. However, as the sediments were barren of any kind of siliceous microfossils, and the fact that "Glacial" sediments were not penetrated, information on whether the preglacial siliceous oozes were present that far north was not obtained. It will be of great interest to learn whether the Paleogene siliceous oozes, occurring further south in the Norwegian Sea, did extend into the Arctic Ocean. Only core-catcher samples were prepared and studied for radiolarians (Figure 11).

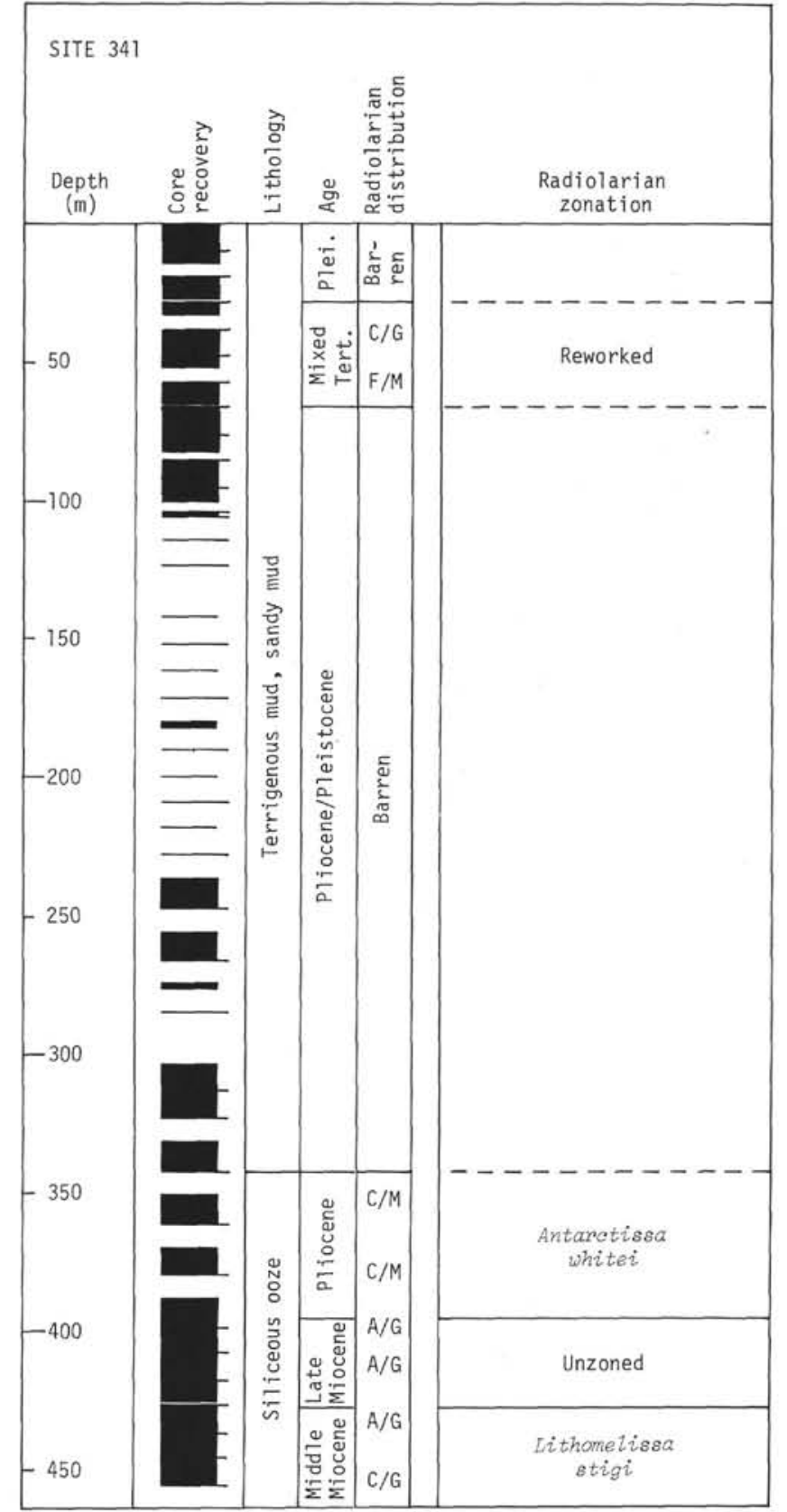

Figure 10. Site summary - Site 341.

\section{Mohns Ridge}

\section{Site 345}

This site was located in the western part of the Lofoten Basin, near the eastern flank of the Mohns Ridge. Pliocene-Pleistocene sediments were characterized by being barren in radiolarians (Figure 12, Table 16). Early Miocene radiolarian assemblages were recovered in Samples 6-1, 43-45 cm to 10-5, 30-32 cm (Figure 12 , Table 17). Other preglacial sediments were also barren of radiolarians (Figure 12, Table 18). No zonation was done for this site, but the occurrence of Heteracantha dentata in Sample 6-1, 43-45 cm may indicate that this sample belongs to the Stichocorys biconica 
TABLE 14

Samples Studied, Either Barren or Having Displaced Radiolarian Assemblages - Site 341

\begin{tabular}{|c|c|c|}
\hline Core & Section & Interval $(\mathrm{cm})$ \\
\hline 1 & 3 & $88-90$ \\
\hline 1 & & $\mathrm{CC}$ \\
\hline 2 & 2 & $64-66$ \\
\hline 2 & & $\mathrm{CC}$ \\
\hline 3 & 3 & $88-90$ \\
\hline 3 & & $\mathrm{CC}$ \\
\hline 4 & 2 & $94-96$ \\
\hline 4 & & CCa \\
\hline 5 & 3 & $88-90^{a}$ \\
\hline 5 & & $\mathrm{CC}^{\mathrm{a}}$ \\
\hline 6 & 2 & $92-94 a$ \\
\hline 6 & & $\mathrm{CCa}$ \\
\hline 7 & 3 & $92-94^{a}$ \\
\hline 7 & & $\mathrm{CCa}$ \\
\hline 8 & 3 & $83-85$ \\
\hline 8 & & $\mathrm{CC}$ \\
\hline 9 & 3 & $86-88$ \\
\hline 9 & & $\mathrm{CC}$ \\
\hline 10 & 3 & $120-122$ \\
\hline 10 & & $\mathrm{CC}$ \\
\hline 11 & 3 & $100-102$ \\
\hline 11 & & $\mathrm{CC}$ \\
\hline 12 & 3 & $95-97$ \\
\hline 12 & & $\mathrm{CC}$ \\
\hline \multicolumn{3}{|c|}{ Cores 13-15, Core-catcher sample } \\
\hline 16 & 1 & $105-107$ \\
\hline 16 & & $\mathrm{CC}$ \\
\hline 17 & 2 & $70-72$ \\
\hline 17 & & $\mathrm{CC}$ \\
\hline 18 & 1 & $30-32$ \\
\hline 18 & & $\mathrm{CC}$ \\
\hline 19 & 1 & $145-147$ \\
\hline 19 & & $\mathrm{CC}$ \\
\hline 20 & 3 & $95-97$ \\
\hline 20 & & $\mathrm{CC}$ \\
\hline 21 & 3 & $80-82$ \\
\hline 21 & & $\mathrm{CC}$ \\
\hline 22 & 1 & $82-84$ \\
\hline 22 & & $\mathrm{CC}$ \\
\hline 23 & 4 & $51-53$ \\
\hline 23 & & $\mathrm{CC}$ \\
\hline 24 & 3 & $90-92$ \\
\hline 24 & & $\mathrm{CC}$ \\
\hline
\end{tabular}

${ }^{\mathrm{a}}$ Reworked radiolarians.

Zone. However, the occurrence of Gondwanaria japonica and absence of Ceratocyrtis robustus indicate that the faunal assemblage belongs to the Cyrtocapsella eldholmi Zone. Other key species are not present, thus, this zoning is not too exact.

\section{Jan-Mayen Ridge}

\section{Site 346}

This site was located on the Jan-Mayen Ridge, and Pliocene-Pleistocene sediments were characterized by being barren in fossils. However, in Sample 1, CC a good modern fauna existed, dominated by Cycladophora davisiana and Amphimelissa setosa. The preservation was good (Figure 13, Table 19).

Middle Miocene sediments were recovered from Samples 4-2, 95-97 cm to 11, CC. The radiolarian abundance is rare, of a moderate to poor preservation
(Figure 13, Table 19). This section is unzoned, but again, as at Site 345, Heteracantha dentata are present, indicating a maximum age for Sample 4-2, 95-97 cm of upper early Miocene. However, the age is probably younger. The rare radiolarians and their bad stage of preservation do not allow a more exact date. In addition, Velicucullus oddgurneri and Ceratocyrtis mashae were observed.

\section{Site 347}

This site is located a short distance southwest of Site 346 . Only core catchers were studied for radiolarians. An abundant, modern radiolarian assemblage of good preservation was recovered from Sample 1, CC. The rest of the samples were barren of radiolarians (Figure 14).

\section{Site 349}

This site is located on the Jan-Mayen Ridge, southeast of Sites 346 and 347. Nearly all core-catchers samples were barren of any kind of siliceous

TABLE 15

Radiolarian Species, Abundances, Preservation - Site 341

\begin{tabular}{|c|c|c|c|c|c|c|c|c|c|}
\hline $\begin{array}{l}\text { Sample } \\
\text { (Interval } \\
\text { in } \mathrm{cm} \text { ) }\end{array}$ & 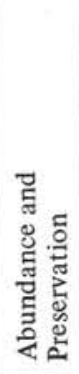 & 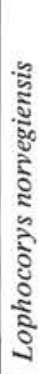 & 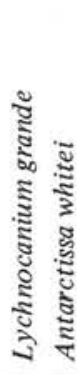 & 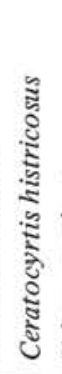 & 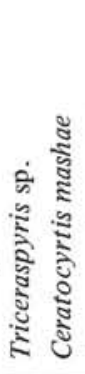 & 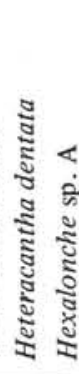 & 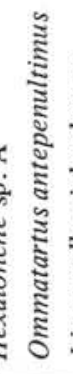 & 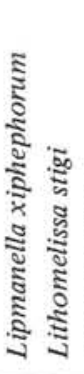 & 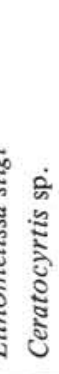 \\
\hline $25-2,118-120$ & $R / P$ & $\mathrm{R}$ & $\mathrm{R} R$ & & $\mathrm{R}$ & & & & \\
\hline $25-5,2-4$ & $\mathrm{~A} / \mathrm{G}$ & & $\mathrm{R}$ & & $\mathrm{R}$ & & & & \\
\hline $25 \mathrm{CC}$ & $\mathrm{C} / \mathrm{M}$ & $\mathrm{R}$ & $\mathrm{R} R$ & & $\mathrm{R}$ & $\mathrm{R}$ & & & \\
\hline $26-2,111-113$ & $\mathrm{C} / \mathrm{M}$ & & $\mathrm{R}$ & & $\mathrm{R}$ & $\mathrm{R}$ & & & \\
\hline $26-5,54-56$ & $\mathrm{C} / \mathrm{M}$ & & $\mathrm{R} R$ & & $\mathrm{R} R$ & $\mathrm{R} R$ & & & \\
\hline $26 \mathrm{CC}$ & $\mathrm{C} / \mathrm{M}$ & & $\mathrm{R} R$ & & $\mathrm{R}$ & $\mathrm{R}$ & & & \\
\hline $27-3,14-16$ & $\mathrm{C} / \mathrm{M}$ & & $\mathrm{R}$ & & & & & & \\
\hline $27-5,82-84$ & $\mathrm{C} / \mathrm{M}$ & & & & $\mathrm{C}$ & & & & \\
\hline $27, \mathrm{CC}$ & $\mathrm{C} / \mathrm{M}$ & $\mathrm{R}$ & & & $\mathrm{F}$ & $\mathrm{R}$ & & & \\
\hline $28-3,79-81$ & $\mathrm{C} / \mathrm{M}$ & & & & $\mathrm{R}$ & & $\mathrm{R}$ & & \\
\hline $28-6,66-68$ & $\mathrm{~F} / \mathrm{M}$ & & & F & $\mathrm{R}$ & & & & \\
\hline $28, \mathrm{CC}$ & $\mathrm{C} / \mathrm{M}$ & $\mathrm{R}$ & & $\mathrm{R}$ & $\mathrm{R}$ & $\mathrm{R}$ & & $\mathrm{R}$ & \\
\hline $29-2,100-102$ & $\mathrm{~F} / \mathrm{M}$ & & & & $\mathrm{R}$ & $\mathrm{R}$ & & & $\mathrm{R}$ \\
\hline $29-5,120-122$ & $\mathrm{~A} / \mathrm{M}$ & & & & & & & & \\
\hline $29, \mathrm{CC}$ & $\mathrm{A} / \mathrm{G}$ & $\mathrm{R}$ & & & F & $\mathrm{R}$ & & & \\
\hline $30-2,110-112$ & $\mathrm{~F} / \mathrm{P}$ & & & & & & & & \\
\hline $30-5,90-92$ & $\mathrm{~F} / \mathrm{P}$ & & & & & & & & \\
\hline $30, \mathrm{CC}$ & $\mathrm{C} / \mathrm{M}$ & & & & & & & & \\
\hline $31-5,17-19$ & $\mathrm{~A} / \mathrm{M}$ & & & & & A & & & \\
\hline $31, \mathrm{CC}$ & $\mathrm{A} / \mathrm{M}$ & & & & & A & & $\mathrm{R}$ & \\
\hline $32-2,101-103$ & $\mathrm{C} / \mathrm{M}$ & & & & & $\mathrm{F}$ & & $\mathrm{R}$ & \\
\hline $32-5,87-89$ & $\mathrm{~F} / \mathrm{M}$ & & & & & $\mathrm{F}$ & & $\mathrm{R}$ & \\
\hline $32, \mathrm{CC}$ & $\mathrm{A} / \mathrm{M}$ & & & & & $\mathrm{R}$ & & $\mathrm{R}$ & \\
\hline $33-2,92-94$ & $\mathrm{C} / \mathrm{M}$ & & & & & $\mathrm{R}$ & & $\mathrm{R}$ & \\
\hline $33-5,110-112$ & $\mathrm{C} / \mathrm{M}$ & & & & & & & $\mathrm{R}$ & \\
\hline $33, \mathrm{CC}$ & $\mathrm{C} / \mathrm{G}$ & & & & & & & $\mathrm{R}$ & \\
\hline $34-2,41-43$ & $\mathrm{~F} / \mathrm{M}$ & & & & & & & $\mathrm{R}$ & \\
\hline $34-5,107-109$ & $\mathrm{~F} / \mathrm{M}$ & & & & & & & $\mathrm{R}$ & \\
\hline $34, \mathrm{CC}$ & $\mathrm{C} / \mathrm{M}$ & & & & & & & $\mathrm{R}$ & \\
\hline
\end{tabular}




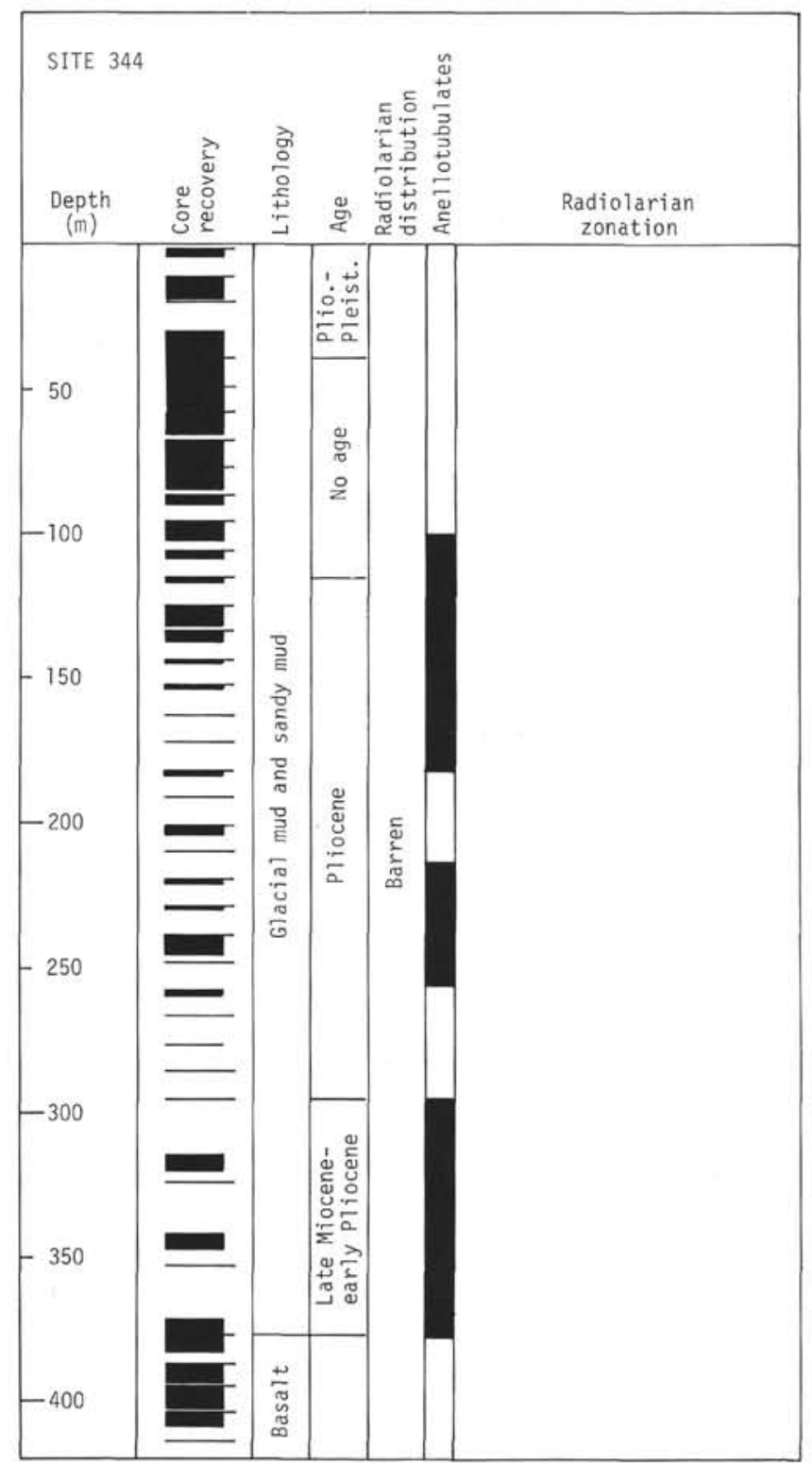

Figure 11. Site summary - Site 344.

microfossils. However, Samples 1-1, 10-12 cm and 1, $\mathrm{CC}$ had a good, well preserved, modern radiolarian fauna. One specimen of Amphimelissa sp. was recognized in Sample 13, CC. This was also found at Site 338, indicating a late Eocene age (Figure 15).

\section{Site 350}

This site is the southernmost site on the Jan-Mayen Ridge. All core-catcher samples, except for 1, CC and 3 , CC, where few radiolarians of a bad preservation were observed, are barren of any kind of siliceous microfossils (Figure 16). One specimen of Heteracantha dentata was present in Sample 3, CC, and using its range from Site 338 , this sample may be referred to the upper early Miocene-middle Miocene. However, this is not accurate dating, as all other key species are missing.

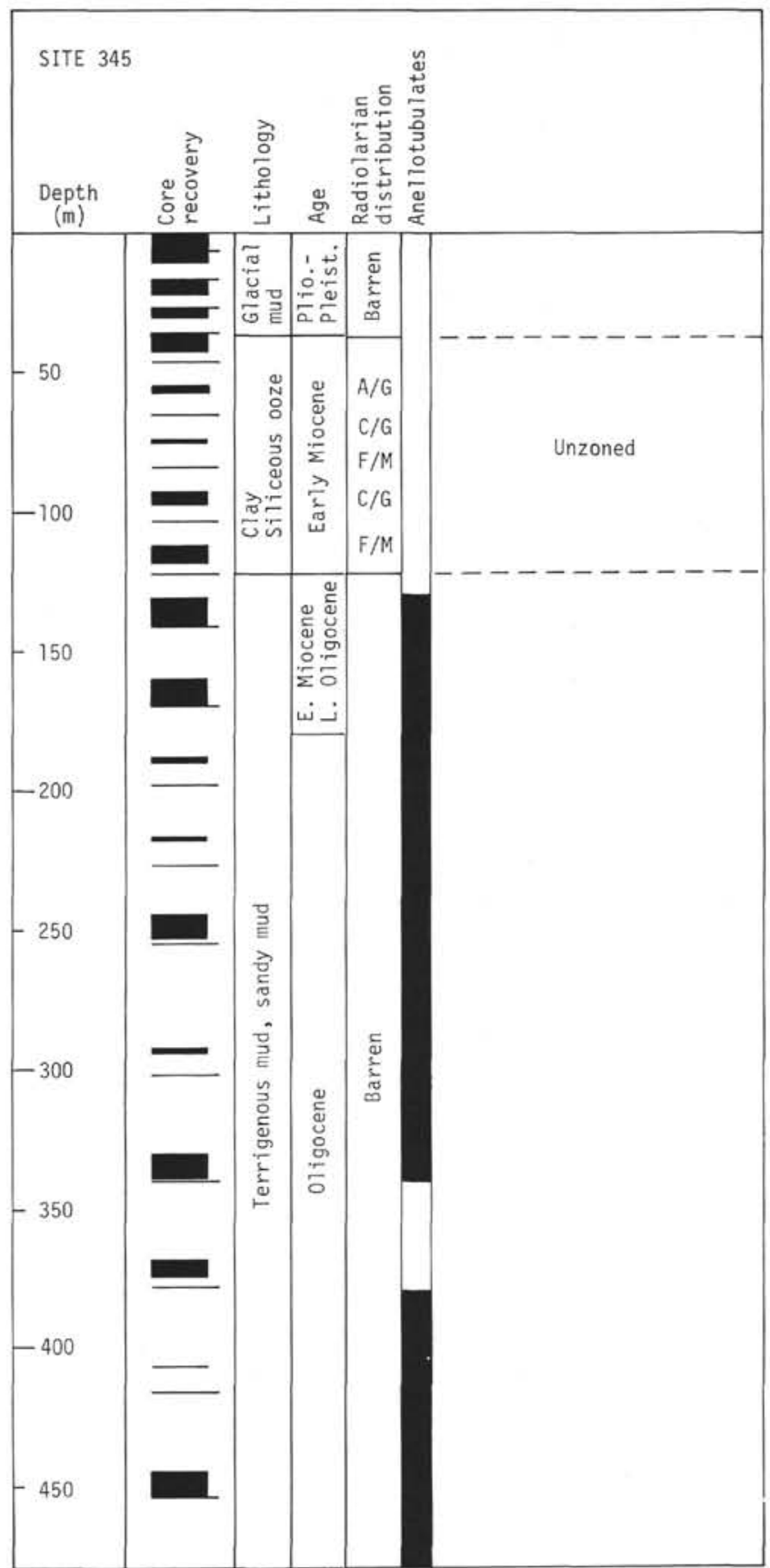

Figure 12. Site summary - Site 345.

\section{Iceland Plateau}

\section{Site 348}

This site is located west of the Jan-Mayen Ridge and is characterized by having a relatively rich, and well to moderately preserved radiolarian fauna from Recent to middle Miocene (Figure 17, Tables 20 and 21). The abundance and preservation of radiolarians vary greatly throughout this section. However, two zones could be identified, the Cycladophora davisiana Zone, ranging throughout the Pleistocene, and the Antarctissa whitei Zone, ranging throughout the Pliocene and slightly into 
TABLE 16

Pliocene-Pleistocene Samples Studied for Radiolarians - Site 345

\begin{tabular}{lcc}
\hline Core & Section & Interval $(\mathrm{cm})$ \\
\hline 1 & 1 & $0-2$ \\
1 & 1 & $103-105$ \\
1 & 2 & $65-67$ \\
1 & 3 & $52-54$ \\
1 & 4 & $71-73$ \\
1 & & CC \\
2 & 1 & $49-51$ \\
2 & 1 & $69-71$ \\
2 & 2 & $47-49$ \\
2 & 2 & $94-96$ \\
2 & 3 & $44-46$ \\
2 & 3 & $109-111$ \\
2 & & CC \\
3 & 1 & $106-108$ \\
3 & 2 & $82-84$ \\
3 & 3 & $39-41$ \\
3 & 3 & $129-131$ \\
3 & & CC \\
4 & 1 & $60-62$ \\
4 & 2 & $52-54$ \\
& & CC \\
\hline
\end{tabular}

TABLE 17

Selected Radiolarians from Site 345

\begin{tabular}{|c|c|c|c|c|c|c|c|c|c|c|}
\hline $\begin{array}{l}\text { Sample } \\
\text { (Interval } \\
\text { in } \mathrm{cm} \text { ) }\end{array}$ & 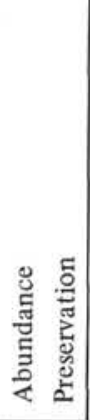 & 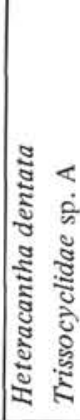 & 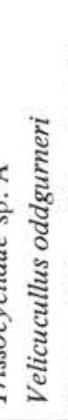 & 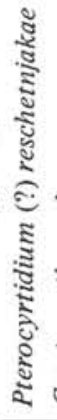 & 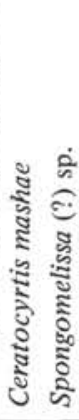 & 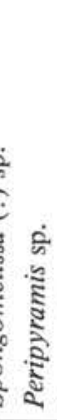 & 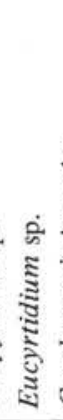 & 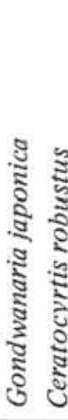 & 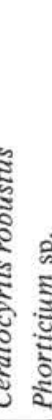 & \\
\hline $6-1,43-45$ & $\mathrm{R} \quad \mathrm{P}$ & R & & & & & & & & \\
\hline $6-1,80-82$ & $\mathrm{R} \quad \mathrm{P}$ & & & & & & & & & \\
\hline $6-1,126-128$ & $\mathrm{~F} \quad \mathrm{P}$ & $\mathrm{R}$ & & & & & & & & \\
\hline $6-2,17-19$ & C $\mathrm{G}$ & $\mathrm{R}$ & $R$ & F & $\mathrm{R}$ & & & & & \\
\hline $6-2,96-98$ & A $\mathrm{M}$ & & A & $\mathrm{F}$ & $\mathrm{F}$ & $\mathrm{F}$ & & & & \\
\hline $6, \mathrm{CC}$ & A $G$ & $\mathrm{R}$ & $\mathrm{A}$ & $\mathrm{F}$ & F A & $R$ & & & & \\
\hline $7-2,88-90$ & C $\quad \mathrm{G}$ & & A & $\mathrm{R}$ & F $R$ & $\mathrm{R}$ & $\mathrm{R}$ & & & \\
\hline $7, \mathrm{CC}$ & $\mathrm{R} \quad \mathrm{P}$ & & $\mathrm{R}$ & & $\mathrm{R}$ & & & & & \\
\hline $8-1,125-127$ & C $\quad \mathrm{M}$ & $\mathrm{R}$ & $R$ & $\mathrm{R}$ & $\mathrm{R} R$ & $\mathrm{R}$ & $\mathrm{R}$ & $\mathrm{R}$ & & \\
\hline $8-2,118-120$ & C $\quad \mathrm{M}$ & & & $\mathrm{F}$ & $\mathrm{F} F$ & & & $\mathrm{R}$ & & \\
\hline $8-3,121-123$ & $\mathrm{~F} \quad \mathrm{M}$ & & & $\mathrm{R}$ & $\mathrm{R} F$ & & & & & \\
\hline $8-4,58-60$ & $\mathrm{~F} \quad \mathrm{M}$ & & $\mathrm{R}$ & $\mathrm{R}$ & $\mathrm{R} F$ & & & & & \\
\hline $8, \mathrm{CC}$ & $C \quad \mathrm{G}$ & $\mathrm{R}$ & $R$ & $\mathrm{~F}$ & $\mathrm{R} C$ & & $\mathrm{R}$ & $\mathrm{F}$ & & \\
\hline $9-1,141-143$ & $\mathrm{R} \quad \mathrm{M}$ & $\mathrm{R}$ & & & $\mathrm{R}$ & & & & & \\
\hline $9-2,40-42$ & $\mathrm{~F} \quad \mathrm{M}$ & $\mathrm{R}$ & & $\mathrm{R}$ & $\mathrm{R}$ & & & & & \\
\hline $9-3,50-52$ & $\mathrm{R} \quad \mathrm{M}$ & $\mathrm{R}$ & $\mathrm{R}$ & $\mathrm{R}$ & & & & & & \\
\hline $9-4,40-42$ & $\mathrm{R} \quad \mathrm{P}$ & & & & & & & & & \\
\hline $9, \mathrm{CC}$ & $\mathrm{F} \quad \mathrm{M}$ & $\mathrm{R}$ & & $\mathrm{R}$ & & & & & & \\
\hline $10-0,30-32$ & $C \mathrm{G}$ & $\mathrm{R}$ & $\mathrm{R}$ & $\mathrm{R}$ & $\mathrm{R}$ & & & $\mathrm{C}$ & $\mathrm{C}$ & \\
\hline $10-1,35-37$ & C $\mathrm{M}$ & & & & & & & & $\mathrm{C}$ & \\
\hline $10-2,30-32$ & F $\quad \mathrm{M}$ & & $\mathrm{R}$ & & $\mathrm{R}$ & & & & $\mathrm{C} F$ & F \\
\hline $10-3,45-47$ & $\mathrm{~F} \quad \mathrm{M}$ & & & & & & & & R F & F \\
\hline $10-4,30-32$ & $\mathrm{~F} \quad \mathrm{M}$ & & & & $\mathrm{R}$ & & & $\mathrm{F}$ & $\mathrm{F} F$ & F \\
\hline $10-5,30-32$ & $\mathrm{~F} \quad \mathrm{M}$ & & & & $\mathrm{R}$ & & & & $\mathrm{F} F$ & F \\
\hline
\end{tabular}

TABLE 18

Pre-Glacial Samples Barren for Radiolarians - Site 345

\begin{tabular}{ccl}
\hline Core & Section & $\begin{array}{c}\text { Interval } \\
(\mathrm{cm})\end{array}$ \\
\hline 5 & 1 & $88-90$ \\
5 & 2 & $66-68$ \\
5 & 3 & $35-37$ \\
5 & 4 & $11-13$ \\
5 & 4 & $105-107$ \\
5 & & CC \\
10 & 6 & $30-32$ \\
10 & & CC \\
11 & 1 & $30-32$ \\
11 & 2 & $20-22$ \\
11 & 3 & $35-37$ \\
11 & 4 & $30-31$ \\
11 & 5 & $30-32$ \\
11 & 6 & $20-22$ \\
11 & & CC
\end{tabular}

Cores 12-30, Core-catcher samples

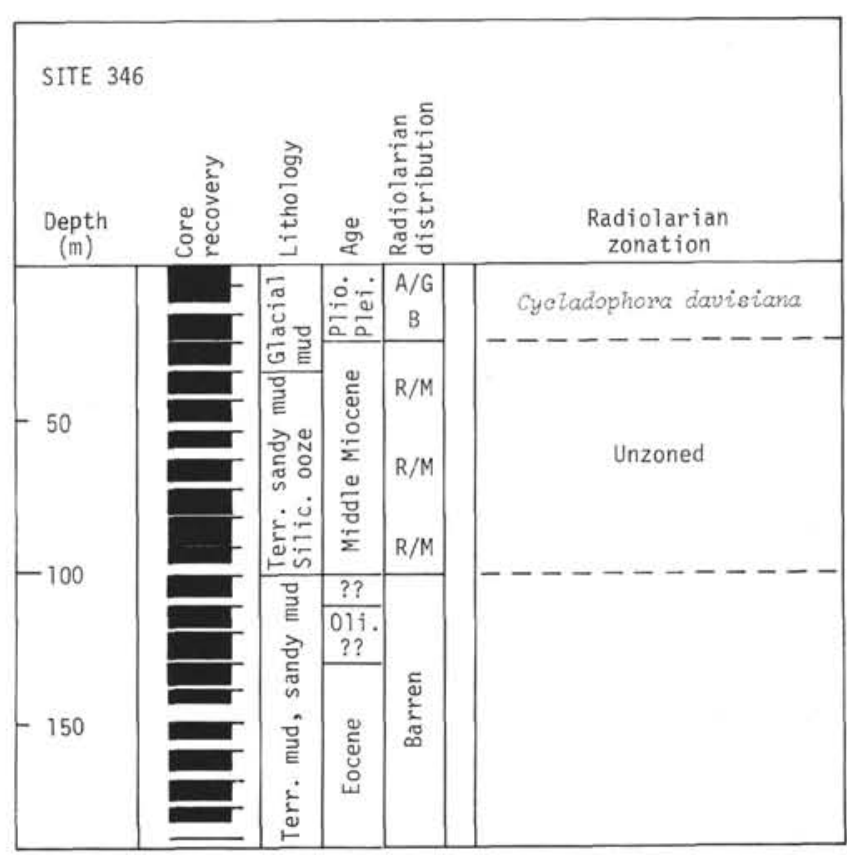

Figure 13. Site summary - Site 346.

the late Miocene. From Samples 12, CC to 18, CC there is an unzoned interval, corresponding with a similar unzoned interval at Site 341. The mass occurrence of Hexalonche sp. A is believed to be a good time indicator, and is present at Site 338 (Sample 7, CC), Site 341 (Sample 31-5, 17-19 cm), and Site 348 (Sample 15-2, 30$32 \mathrm{~cm}$ ) of lower late Miocene. This site is also peculiar in having a high occurrence of phaeodarians in Samples 5, CC through 7, CC (Plate 13, Figures 15-21).

\section{Ecological Interpretations}

From the site summaries (Figures 2-17), it was seen that the "Glacial" sediments varied considerably in thickness. It is of interest to observe that the "Glacial" sediments are principally barren of radiolarians at sites 
TABLE 19

Samples Studied for Radiolarians - Site 346

\begin{tabular}{|c|c|c|}
\hline Core & Section & Interval $(\mathrm{cm})$ \\
\hline 1 & 1 & $30-32$ \\
\hline 1 & & $\mathrm{CC}^{\mathrm{a}}$ \\
\hline 2 & 3 & $10-12$ \\
\hline 2 & & $\mathrm{CC}$ \\
\hline 3 & 3 & $130-132$ \\
\hline 3 & & $\mathrm{CC}$ \\
\hline 4 & 2 & $95-97 a$ \\
\hline 4 & & $\mathrm{CC}^{\mathrm{a}}$ \\
\hline 5 & 2 & $60-62^{a}$ \\
\hline 5 & & $\mathrm{CC}^{\mathrm{a}}$ \\
\hline 6 & 3 & $30-32^{a}$ \\
\hline 6 & & $\mathrm{CC}^{\mathrm{a}}$ \\
\hline 7 & 3 & $35-37^{a}$ \\
\hline 7 & & $\mathrm{CC}^{\mathrm{a}}$ \\
\hline 8 & 3 & $25-27^{a}$ \\
\hline 8 & & $\mathrm{CC}$ \\
\hline 9 & 3 & $130-132^{\mathrm{a}}$ \\
\hline 9 & & $\mathrm{CC}^{\mathrm{a}}$ \\
\hline 10 & 3 & $15-17^{a}$ \\
\hline 10 & & $\mathrm{CCa}$ \\
\hline 11 & 3 & $95-97 a$ \\
\hline 11 & & $\mathrm{CC}^{\mathrm{a}}$ \\
\hline 12 & 3 & $110-112$ \\
\hline 12 & & $\mathrm{CC}$ \\
\hline 13 & 3 & $20-22$ \\
\hline 13 & & $\mathrm{CC}$ \\
\hline \multicolumn{3}{|c|}{ Cores 14-20, Core-catcher samples } \\
\hline
\end{tabular}

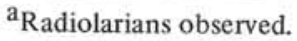

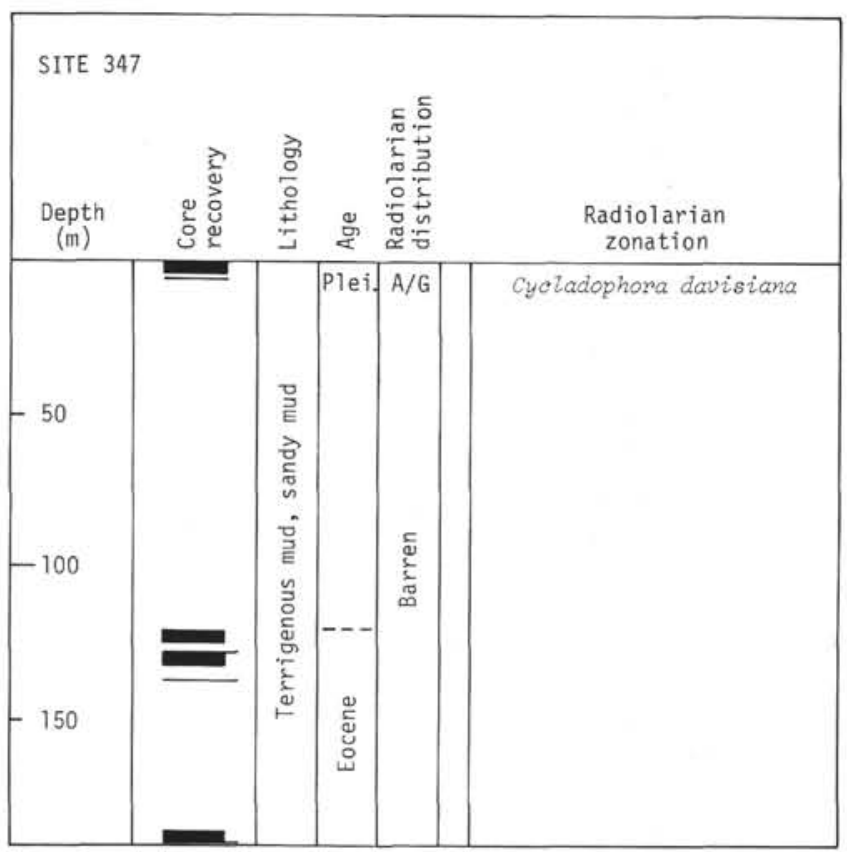

Figure 14. Site summary - Site 347.

located in the eastern and in the northern parts of the Norwegian Sea, Sites 341 and 344, having 323 meters and 320 meters of "Glacial" sediments, respectively. However, at most of the sites in the western part of the Norwegian Sea (Sites 346, 347, 348, and 349), the "Glacial" sediments average 50 meters in thickness, varying from 32 to 64 meters at Sites 346 and 348,

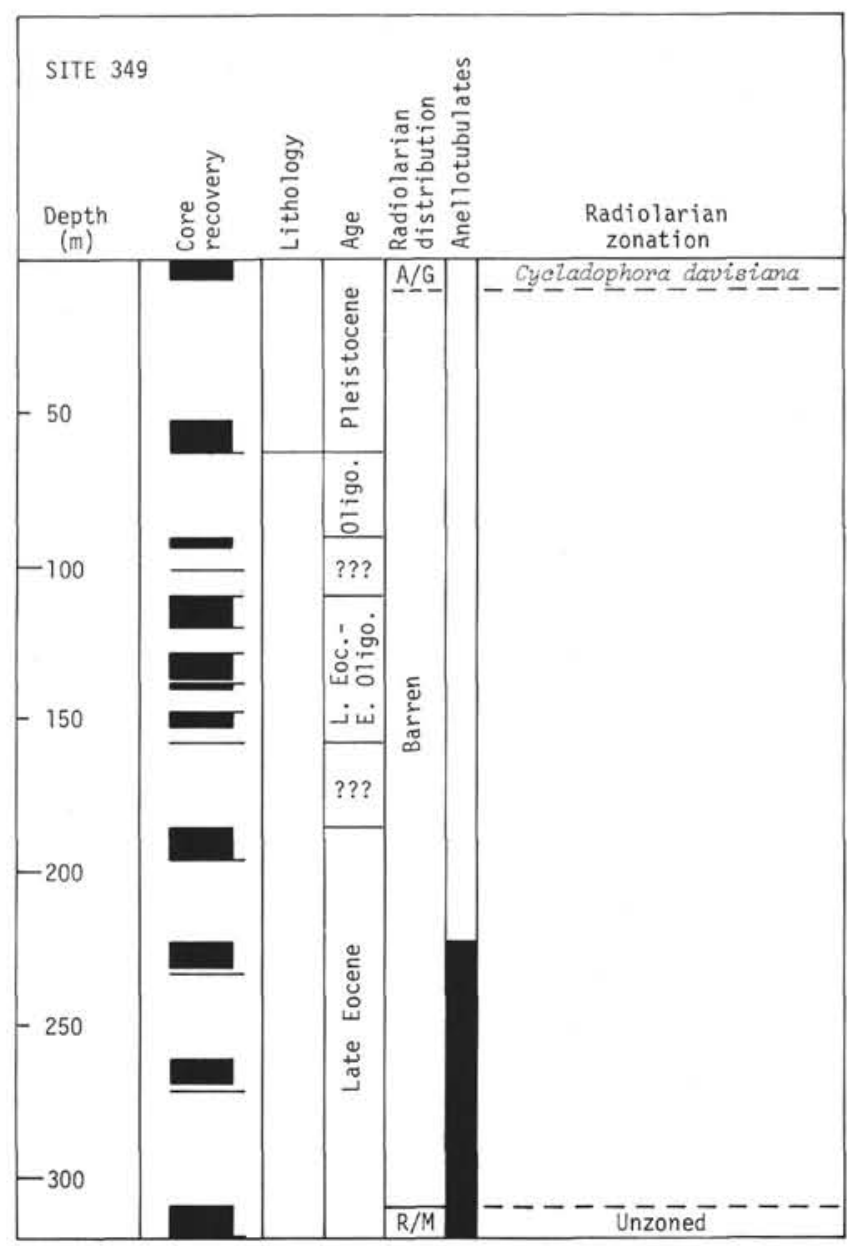

Figure 15. Site summary - Site 349.

respectively. The sediments have a relatively rich and well-preserved radiolarian fauna. These radiolarian distribution patterns are most likely explained by a combination of masking, dissolution, and production. For the Jan-Mayen area sites there is no nearby source of terrigenous sediments, assuming that the sediments derived from Greenland are trapped on the western side of the present spreading axis. However, on the $\mathrm{V} \phi$ ring Plateau and at the Knipovich Ridge, the buried V $\phi$ ring Plateau Escarpment and the Knipovich Ridge have trapped sediments being derived from Norway and the Barents Sea and Spitzbergen, respectively. Therefore, the high influx of glacial-derived terrigenous material at Sites 341 and 344 may be masking the radiolarians. It should also be kept in mind that as a great deal of terrigenous material is put into suspension in the oceanic environment surface production might have been decreased.

For the Jan-Mayen sites, as a consequence of the fact that most of the terrigenous sediments are trapped to the west, the masking effect is less pronounced. The water has less suspended material, allowing a higher production, and therefore generally a better preservation of siliceous microfossils in the sediments.

Antarctissa whitei is generally rare in the eastern Norwegian Sea (Site 341), while it is abundant at Site 348 in the western Norwegian Sea. This might indicate 


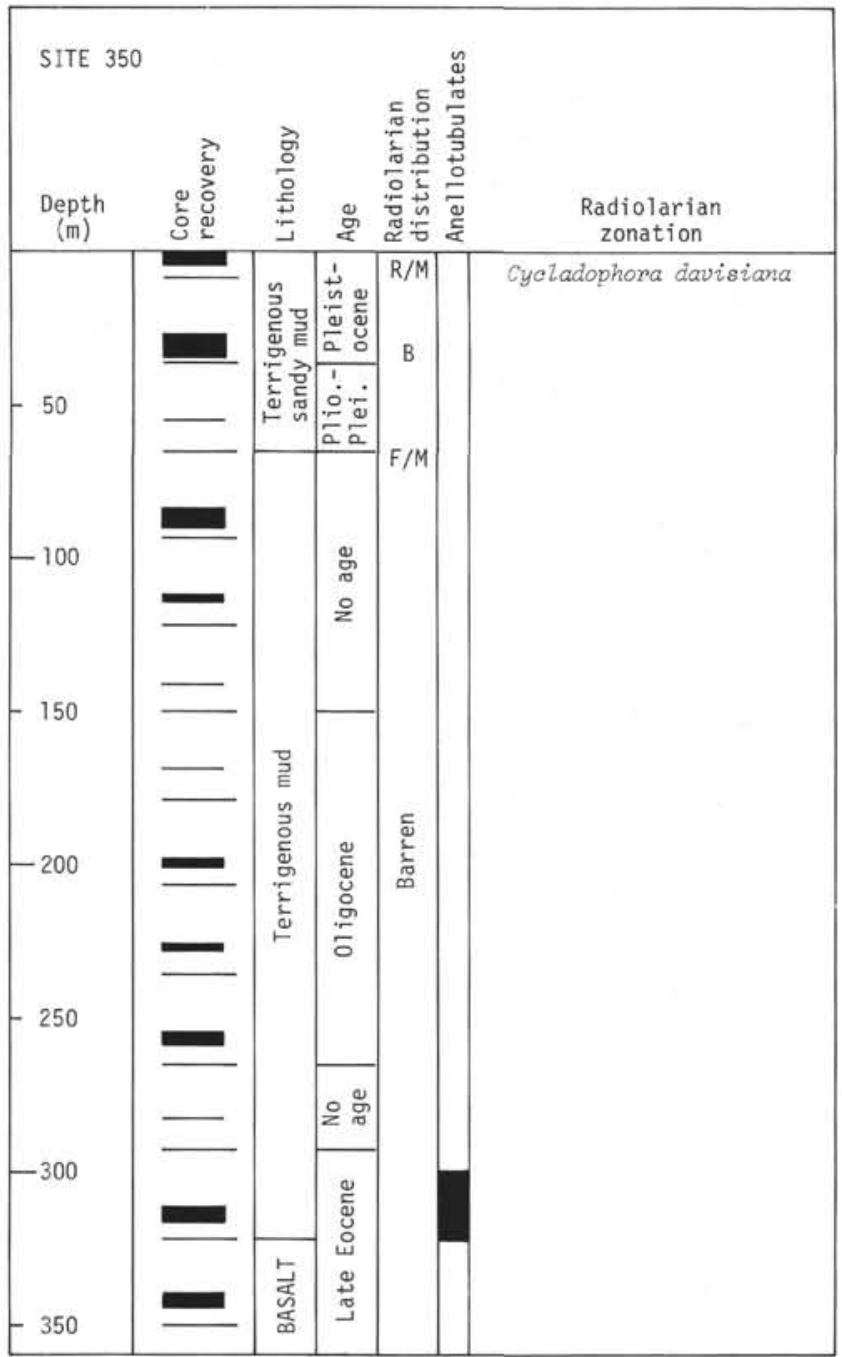

Figure 16. Site summary - Site 350.

that $A$. whitei is associated with cold water, and therefore, reflects a cold water current system in the western Norwegian Sea. This system, only to some extent, influences the radiolarian distribution further east in the Norwegian Sea.

The preglacial sediments again show an interesting distribution pattern. All sites in the Icelandic Plateau and Jan-Mayen area are characterized by being almost barren, or by having rare radiolarians of moderate to poor preservation. However, in the V $\phi$ ring Plateau, preglacial sediments are characterized by rich faunas of a good preservation. This distribution pattern is a result of active spreading and a high input of terrigenous material causing a suspension of loaded water. This, in effect, reduced the productivity in the western Norwegian Sea during most of the Oligocene and Miocene. The eastern Norwegian Sea is receiving limited amounts of terrigenous sediments, and is accumulating biogenic siliceous oozes.

The submergence of the Iceland-Faeroe Ridge is believed to have been definite in the lower early Miocene, as the occurrence of Velicucullus oddgurneri and Cyrtocapsella tetrapera in the Norwegian Sea sediments is in-

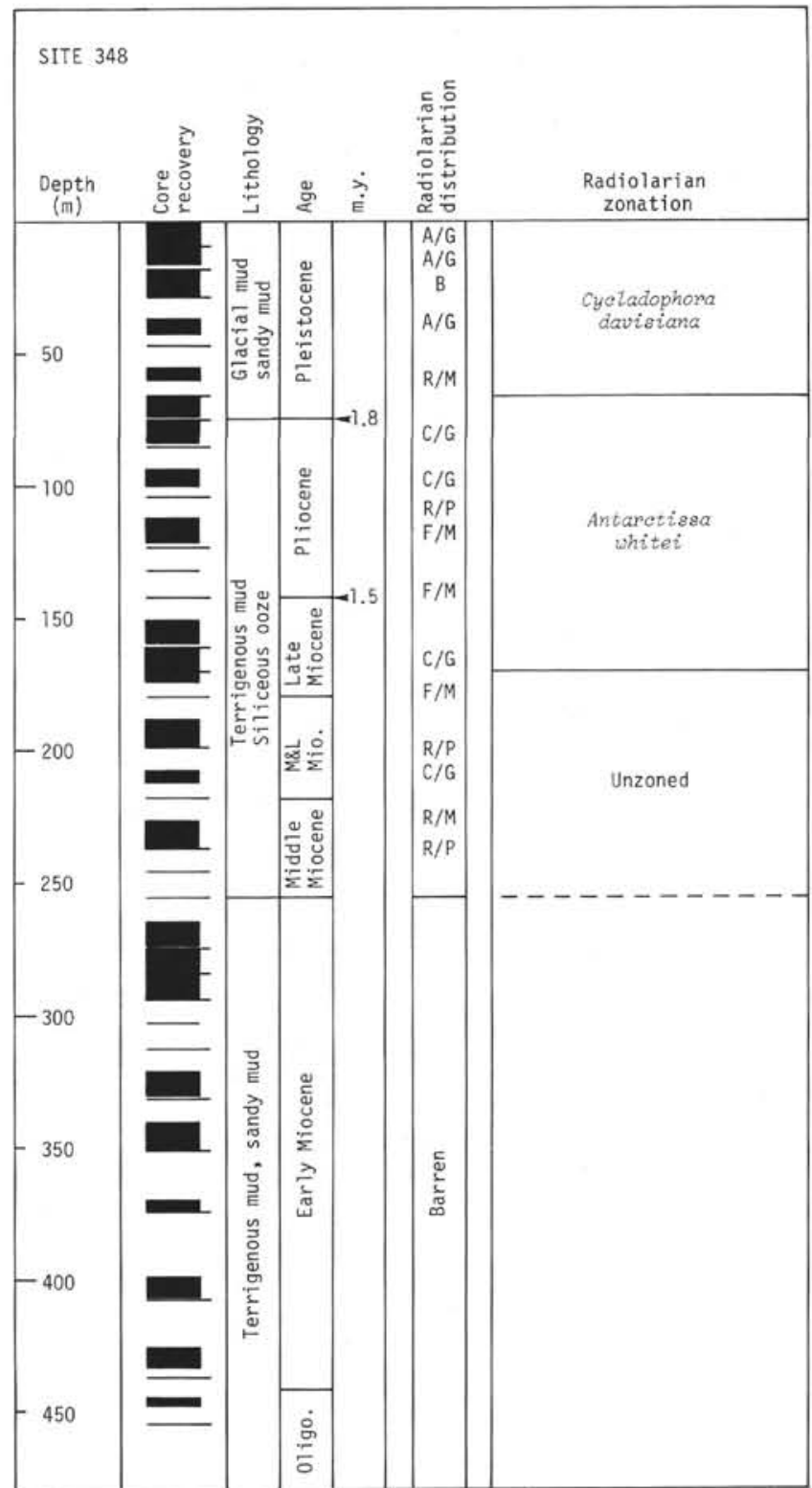

Figure 17. Site summary - Site 348.

terpreted as a transportation effect from the north Atlantic water-masses which at this time got free access to the Norwegian Sea.

As learned from Sites 338 and 342, only traces of key species of importance for the lower latitude radiolarian zonation were observed. This is taken as evidence that faunal transportation by the North Atlantic Current, from the North Atlantic into the Norwegian Sea, was very limited. Therefore, biogenic siliceous oozes that accumulated in the Norwegian Sea, are concluded to have been produced by a native fauna and flora. The well developed Eocene siliceous oozes on the $\mathrm{V} \phi$ ring Plateau present another problem. What was the circulation system in the Norwegian Sea during the Eocene? There was apparently no connection with the Atlantic Ocean to the south, but fauna similarities between the $\mathrm{V} \phi$ ring Plateau and different wells in Siberia (Kozlova and Gorbovetz, 1966) leads to the conclusion that the 
TABLE 20

Pliocene-Pleistocene Samples Studied for Radiolarians - Site 348

\begin{tabular}{|c|c|c|}
\hline Core & Section & Interval $(\mathrm{cm})$ \\
\hline 1 & 1 & $65-67^{\mathrm{a}}$ \\
\hline 1 & 2 & $85-87^{a}$ \\
\hline 1 & 3 & $75-77$ \\
\hline 1 & 4 & $70-72^{\mathrm{a}}$ \\
\hline 1 & 5 & $70-72$ \\
\hline 1 & 6 & $70-72$ \\
\hline 1 & & $\mathrm{CC}$ \\
\hline 2 & 1 & $52-54^{a}$ \\
\hline 2 & 1 & $90-92^{\mathrm{a}}$ \\
\hline 2 & 2 & $100-102$ \\
\hline 2 & 3 & $90-92$ \\
\hline 2 & 4 & $60-62$ \\
\hline 2 & & CC \\
\hline 3 & 1 & $66-68$ \\
\hline 3 & 2 & $72-74$ \\
\hline 3 & 4 & $70-72$ \\
\hline 3 & 5 & $74-76$ \\
\hline 3 & 6 & $70-72$ \\
\hline 3 & & $\mathrm{CC}$ \\
\hline 4 & 1 & $104-106$ \\
\hline 4 & 2 & $50-52^{\mathrm{a}}$ \\
\hline 4 & 2 & $106-108$ \\
\hline 4 & 3 & $41-43$ \\
\hline 4 & 3 & $145-147$ \\
\hline 4 & & $\mathrm{CC}$ \\
\hline 5 & 1 & $105-107$ \\
\hline 5 & 2 & $88-90^{a}$ \\
\hline 5 & 3 & $11-13^{a}$ \\
\hline 5 & 3 & $78-80^{\mathrm{a}}$ \\
\hline 5 & 5 & $147-149^{a}$ \\
\hline 5 & & $\mathrm{CC}^{\mathrm{a}}$ \\
\hline 6 & 3 & $50-52^{\mathrm{a}}$ \\
\hline 6 & 3 & $110-112^{a}$ \\
\hline 6 & & $\mathrm{CC}^{\mathrm{a}}$ \\
\hline 7 & 3 & $45-57 \mathrm{a}$ \\
\hline 7 & 3 & $115-117^{a}$ \\
\hline 7 & & $\mathrm{CC}^{\mathrm{a}}$ \\
\hline 8 & 3 & $55-57^{a}$ \\
\hline 8 & 3 & $140-142^{a}$ \\
\hline 8 & & $\mathrm{CC}^{\mathrm{a}}$ \\
\hline 9 & 3 & $30-32^{a}$ \\
\hline 9 & 3 & $100-102^{\mathrm{a}}$ \\
\hline 9 & & $\mathrm{CC}^{\mathrm{a}}$ \\
\hline 10 & & $\mathrm{CCa}^{\mathrm{a}}$ \\
\hline
\end{tabular}

${ }^{a}$ Radiolarians observed.

Norwegian Sea and the Arctic Ocean did have common radiolarian species. In other words, there must have been some kind of water exchange between the two seas. However, the circulation pattern during Eocene time is still unknown, and the opening and connection of the northern Norwegian Sea with the Arctic Ocean is still not fully understood.

\section{SUMMARY OF THE RADIOLARIAN STRATIGRAPHY}

For the 16 sites drilled, radiolarians were recovered from 10 sites (Table 22). Based on the radiolarians from these sites, it was possible to work out a radiolarian zonation, which is suggested in Table 23. It should here be pointed out that the following boundaries are not well defined, and they are indicated with broken lines in Table 23 in the time column to the right: the early-
TABLE 21

Radiolarian Species, Abundances and Preservation - Site 348

\begin{tabular}{|c|c|c|c|c|c|c|c|c|}
\hline $\begin{array}{c}\text { Sample } \\
\text { (Interval } \\
\text { in } \mathrm{cm} \text { ) }\end{array}$ & 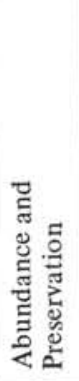 & 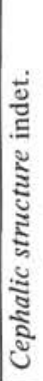 & 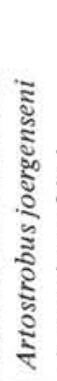 & 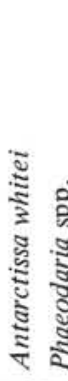 & 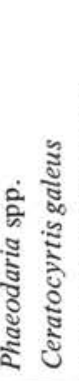 & 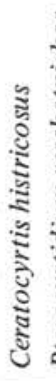 & 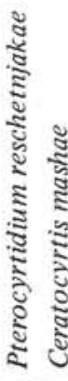 & 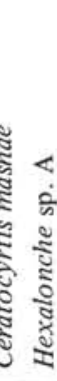 \\
\hline $5-1,105-107$ & B & & & & & & & \\
\hline $5-2,88-90$ & $\mathrm{R} / \mathrm{M}$ & $\mathrm{R}$ & & & & & & \\
\hline $5-3,11-13$ & $\mathrm{~F} / \mathrm{M}$ & $\mathrm{R}$ & & & & & & \\
\hline $5-3,78-80$ & $\mathrm{C} / \mathrm{G}$ & A & & & & & & \\
\hline $5-5,147-149$ & $\mathrm{R} / \mathrm{M}$ & F & & & & & & \\
\hline $5, \mathrm{CC}$ & $\mathrm{C} / \mathrm{M}$ & $\mathrm{R}$ & $\mathrm{R}$ & C $\mathrm{R}$ & $\mathrm{R} \quad \mathrm{R}$ & & & \\
\hline $6-3,50-52$ & $\mathrm{~A} / \mathrm{G}$ & & $\mathrm{R}$ & A $\mathrm{R}$ & $\mathrm{R} R$ & & & \\
\hline $6-3,110-112$ & $\mathrm{C} / \mathrm{G}$ & & $\mathrm{R}$ & A $\mathrm{R}$ & $\mathrm{R} R$ & & $\mathrm{R}$ & \\
\hline $6, \mathrm{CC}$ & $\mathrm{C} / \mathrm{G}$ & & $\mathrm{R}$ & A A & A & & & \\
\hline $7-3,45-47$ & $\mathrm{C} / \mathrm{G}$ & & $\mathrm{R}$ & C $\mathrm{R}$ & $\mathrm{R}$ & & & \\
\hline $7-3,115-117$ & $\mathrm{C} / \mathrm{G}$ & & & C $\mathrm{R}$ & $\mathrm{R}$ & & & \\
\hline $7, \mathrm{CC}$ & $\mathrm{C} / \mathrm{M}$ & & & $\mathrm{F} R$ & $\mathrm{R}$ & $\mathrm{R}$ & & \\
\hline $8-3,55-57$ & $\mathrm{C} / \mathrm{M}$ & & & F & & $\mathrm{R}$ & & \\
\hline $8-3,140-142$ & $\mathrm{~F} / \mathrm{M}$ & & & & & $\mathrm{R}$ & & \\
\hline $8, \mathrm{CC}$ & $\mathrm{R} / \mathrm{P}$ & & & & & & & \\
\hline $9-3,30-32$ & $\mathrm{R} / \mathrm{M}$ & & & & & & & \\
\hline $9-3,100-102$ & $\mathrm{R} / \mathrm{M}$ & & & & & & & \\
\hline $9, \mathrm{CC}$ & $\mathrm{F} / \mathrm{G}$ & & & $\mathrm{R}$ & & & & \\
\hline $10, \mathrm{CC}$ & $\mathrm{F} / \mathrm{M}$ & & & $\mathrm{R}$ & & & & \\
\hline $11-3,30-32$ & $\mathrm{C} / \mathrm{M}$ & & $\mathrm{R}$ & & & & & \\
\hline $11-3,120-122$ & $\mathrm{C} / \mathrm{G}$ & & $\mathrm{R}$ & $\mathrm{R}$ & & & & $\mathrm{R}$ \\
\hline $11, \mathrm{CC}$ & $\mathrm{F} / \mathrm{M}$ & & & & & & & $\mathrm{R}$ \\
\hline $12-3,30-32$ & $\mathrm{C} / \mathrm{G}$ & & $\mathrm{R}$ & $\mathrm{R}$ & & & & $\mathrm{R}$ \\
\hline $12-3,120-122$ & $C / G$ & & $\mathrm{R}$ & $\mathrm{R}$ & & & & R \\
\hline $12, \mathrm{CC}$ & $\mathrm{C} / \mathrm{G}$ & & $\mathrm{R}$ & $\mathrm{R}$ & & & & $\mathrm{R}$ \\
\hline $13-2,30-32$ & $\mathrm{C} / \mathrm{G}$ & & $\mathrm{R}$ & & & & & \\
\hline $13-2,120-122$ & $\mathrm{R} / \mathrm{P}$ & & & & & & & \\
\hline $13, \mathrm{CC}$ & $\mathrm{F} / \mathrm{M}$ & & & & & & & \\
\hline $14-3,30-32$ & $\mathrm{~F} / \mathrm{G}$ & & & & & & & \\
\hline $14-3,120-122$ & $\mathrm{~F} / \mathrm{M}$ & & & & & & & \\
\hline $14, \mathrm{CC}$ & $\mathrm{R} / \mathrm{P}$ & & & & & & & $\mathrm{R}$ \\
\hline $15-2,30-32$ & $\mathrm{C} / \mathrm{G}$ & & & & & & & A \\
\hline $15-2,120-122$ & $\mathrm{~F} / \mathrm{M}$ & & & & & & & $\mathrm{R}$ \\
\hline $15, \mathrm{CC}$ & $\mathrm{C} / \mathrm{M}$ & & & & & & & $\mathrm{R}$ \\
\hline $16-3,30-32$ & $\mathrm{R} / \mathrm{M}$ & & & & & & & $\mathrm{R}$ \\
\hline $16-3,120-122$ & $\mathrm{R} / \mathrm{G}$ & & & & & & & \\
\hline $16, \mathrm{CC}$ & $\mathrm{R} / \mathrm{M}$ & & & & & & & \\
\hline $17, \mathrm{CC}$ & $\mathrm{R} / \mathrm{M}$ & & & & & & & \\
\hline $18, \mathrm{CC}$ & $\mathrm{R} / \mathrm{P}$ & & & & & & & \\
\hline $19-3,45-47$ & B & & & & & & & \\
\hline $19, \mathrm{CC}$ & B & & & & & & & \\
\hline
\end{tabular}

middle Eocene, the middle-late Eocene, the EoceneOligocene, and the middle-late Miocene. Several sites had to be used to compile the suggested local Norwegian Sea radiolarian zonation. Calocyclas talwanii Zone through Lithomelissa stigi Zone was defined from Site 338, except for the Lithomitra sp. A Zone of lower Oligocene age which was suggested as a zone based on the fauna obtained from Site 337. A middle Eocene 
TABLE 22

Radiolarian Zones, Leg 38 Sites

\begin{tabular}{|c|c|c|c|c|c|c|c|c|c|c|c|c|c|c|c|c|c|c|}
\hline \multicolumn{2}{|c|}{ Age } & $\begin{array}{c}\text { Radiolarian } \\
\text { Zones }\end{array}$ & 336 & 337 & 338 & 339 & 340 & 341 & 342 & 343 & 344 & 345 & 346 & 347 & 348 & 349 & 350 & 352 \\
\hline \multicolumn{2}{|c|}{ Pleist. } & $\begin{array}{l}\text { Cycladophora } \\
\text { davisiana }\end{array}$ & $\begin{array}{l}(1- \\
10)\end{array}$ & $\begin{array}{l}1- \\
3\end{array}$ & & & & & & & & & & & $\begin{array}{l}1- \\
5-5\end{array}$ & 1 & & $\begin{array}{l}1- \\
3\end{array}$ \\
\hline \multicolumn{2}{|c|}{ Plio. } & $\begin{array}{c}\text { Antarctissa } \\
\text { whitei }\end{array}$ & & & & & & $\begin{array}{l}25- \\
28-3\end{array}$ & & & & & & & 12 & & & \\
\hline \multirow{6}{*}{$\begin{array}{l}\stackrel{\Xi}{ٍ ~} \\
\stackrel{\Xi}{\Sigma}\end{array}$} & L & Unzoned & & & 7 & & & $\begin{array}{l}28-3- \\
31-5\end{array}$ & & & & & & & $\begin{array}{l}12- \\
15\end{array}$ & & & \\
\hline & \multirow[t]{2}{*}{$\mathrm{M}$} & $\begin{array}{l}\text { Lithomelissa } \\
\text { stigi }\end{array}$ & & & $\begin{array}{r}8-2 \\
10-2\end{array}$ & & & $\begin{array}{l}31-5 . \\
34\end{array}$ & & & & & & & & & & \\
\hline & & $\begin{array}{l}\text { Actinomma } \\
\text { holtedahli }\end{array}$ & & & $\begin{array}{l}10-2- \\
11-3\end{array}$ & & & & $\begin{array}{l}3-2- \\
5\end{array}$ & & & & & & & & & \\
\hline & \multirow{2}{*}{$\mathrm{E}$} & $\begin{array}{c}\text { Stichocorys } \\
\text { biconica }\end{array}$ & & & $\begin{array}{l}11-3 . \\
12\end{array}$ & & & & $\begin{array}{l}5- \\
6\end{array}$ & & & & & & . & & & \\
\hline & & $\begin{array}{l}\text { Cyrtocapsella } \\
\text { eldholmi }\end{array}$ & & & $\begin{array}{l}12- \\
13\end{array}$ & & & & & & & & & & & & & . \\
\hline & & $\begin{array}{l}\text { Gondwanaria } \\
\text { japonica }\end{array}$ & & & $\begin{array}{l}13- \\
18\end{array}$ & & & & & & & & & & & & & \\
\hline \multirow{4}{*}{ 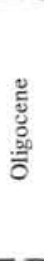 } & & $\begin{array}{c}\text { Velicucullus } \\
\text { oddgurneri }\end{array}$ & & & $\begin{array}{l}18- \\
19-3\end{array}$ & & & & & & & & & & & & & \\
\hline & & $\begin{array}{c}\text { Ceratocyrtis } \\
\text { robustus }\end{array}$ & & & $\begin{array}{l}19-3- \\
21\end{array}$ & & & & & & & & & & & & & \\
\hline & & $\begin{array}{l}\text { Phorticium } \\
\text { sp. A }\end{array}$ & & & $\begin{array}{l}21- \\
24 \cdot 3\end{array}$ & & & & & & & & & & & & & . \\
\hline & & $\begin{array}{l}\text { Lithomitra } \\
\text { sp. A }\end{array}$ & $\begin{array}{l}14- \\
19\end{array}$ & $\begin{array}{c}9 . \\
11\end{array}$ & & & & & & & & & & & & & & \\
\hline \multirow{4}{*}{ 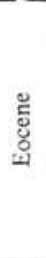 } & \multirow{2}{*}{ L } & $\begin{array}{l}\text { Lophocorys } \\
\text { norvegiensis }\end{array}$ & & & $\begin{array}{l}25- \\
27-3\end{array}$ & & & $11^{7-}$ & & & & & & & & & & \\
\hline & & $\begin{array}{c}\text { Calocyclas } \\
\text { talwanii }\end{array}$ & & & $\begin{array}{l}27-3- \\
29\end{array}$ & & & $\begin{array}{l}1- \\
7\end{array}$ & & & & & & & & & & \\
\hline & $M$ & $\begin{array}{l}\text { Artostrobus } \\
\text { quadriporus }\end{array}$ & & & & $\begin{array}{l}10- \\
12\end{array}$ & & & & & & & & & & & & \\
\hline & $\mathrm{E}$ & $\begin{array}{l}\text { Acronocalpis } \\
\text { tumulosa }\end{array}$ & & & & & & & & $\begin{array}{l}4- \\
5\end{array}$ & & & & & & & & \\
\hline
\end{tabular}

faunal assemblage was recovered from Site 339, and the Artostrobus quadriporus Zone was suggested. An early Eocene fauna assemblage was recovered from Site 343, and the Arachnocalpis tumulosa Zone was suggested.

Late Miocene through Pleistocene sediments were recovered from Sites 341 and 348, and an unzoned interval was suggested for the late Miocene, while the Antarctissa whitei Zone and the Cycladophora davisiana Zone were defined for the Pliocene and Pleistocene, respectively.

\section{TAXONOMY}

In previous DSDP reports, the taxonomic sections have been rather substantial. For space reasons, the present author will minimize this section, as the taxonomy for the majority of the illustrated species is dealt with in one or more of the following papers: Cita et al., (1970), Riedel and Sanfilippo (1970, 1971), Moore (1971), Petrushevskaya and Kozlova (1972), Goll (1972), Dumitrica (1972), Kling, (1973), Sanfilippo and Riedel (1973), Petrushevskaya (1975), and Chen (1975). The reader is referred to these papers for specific descriptions, synonymy lists, and general taxonomic remarks.

In the taxonomic section of this paper, only those species which are of importance for the radiolarian zonation will be dealt with. As some of the species used as zone names are new species, a formal description of these species follows. Table 24 contains listing of species encountered in this study.

\section{Order POLYCYSTINA Ehrenberg}

Polycystina Ehrenberg, 1838, emend. Riedel 1967.

\section{Suborder SPUMELLARIA Ehrenberg, 1875}

Family ACTINOMMIDAE Haeckel, emend. Riedel, 1967

\section{Genus ACTINOMMA Haeckel}

\section{Actinomma holtedahli n. sp.}

(Plate 20, Figures 8, 9)

Actinomma Haeckel, 1862.

Description: Based on examination of 25 specimens, the test is composed of one (?) spongy medullary shell, $50-75 \mu \mathrm{m}$ in diameter. Two cortical shells, outer and inner basically of same structure, outer shell, in most cases, a little thinner with smaller pores, $10 \mu \mathrm{m}$ in diameter than the inner cortical shell with pores about $20 \mu \mathrm{m}$ in diameter. Diameter of outer cortical shell, 200-250 $\mu \mathrm{m}$, while the inner is roughly $20-40 \mu \mathrm{m}$ smaller. The medullar shell is connected to the two cortical shells by numerous (more than 15) thin cylindrical, radial spines, while the two cortical shells are connected with additional bars.

Dimensions of holotype: Outer cortical shell, $250 \mu \mathrm{m}$, inner cortical shell, $210 \mu \mathrm{m}$, and the medullary shell about $75 \mu \mathrm{m}$. Holotype Plate 20, Figure 9. Holotype from Sample 338-15-4, 130-132 cm.

Distribution: Present at Site 338 from Samples 10-2, 146-148 cm through $15-4,130-132 \mathrm{~cm}$.

The specific name holtedahli is in honor of Prof. Dr. phil. Hans Holtedahl, Geological Institute, Dept. B., University of Bergen.

The holotype is stored in the type collection at the Zoological Museum, Bergen, with the journal number 57951 .

Remarks: The generic placing of this species is rather questionable, as it was not possible for the observer to state whether the medullar shell consisted of one or two shells, as illustrated in Dumitrica (1972, pl. 7, fig. 4-6), and, consequently, should have been referred to the genus Rhizosphaera. 


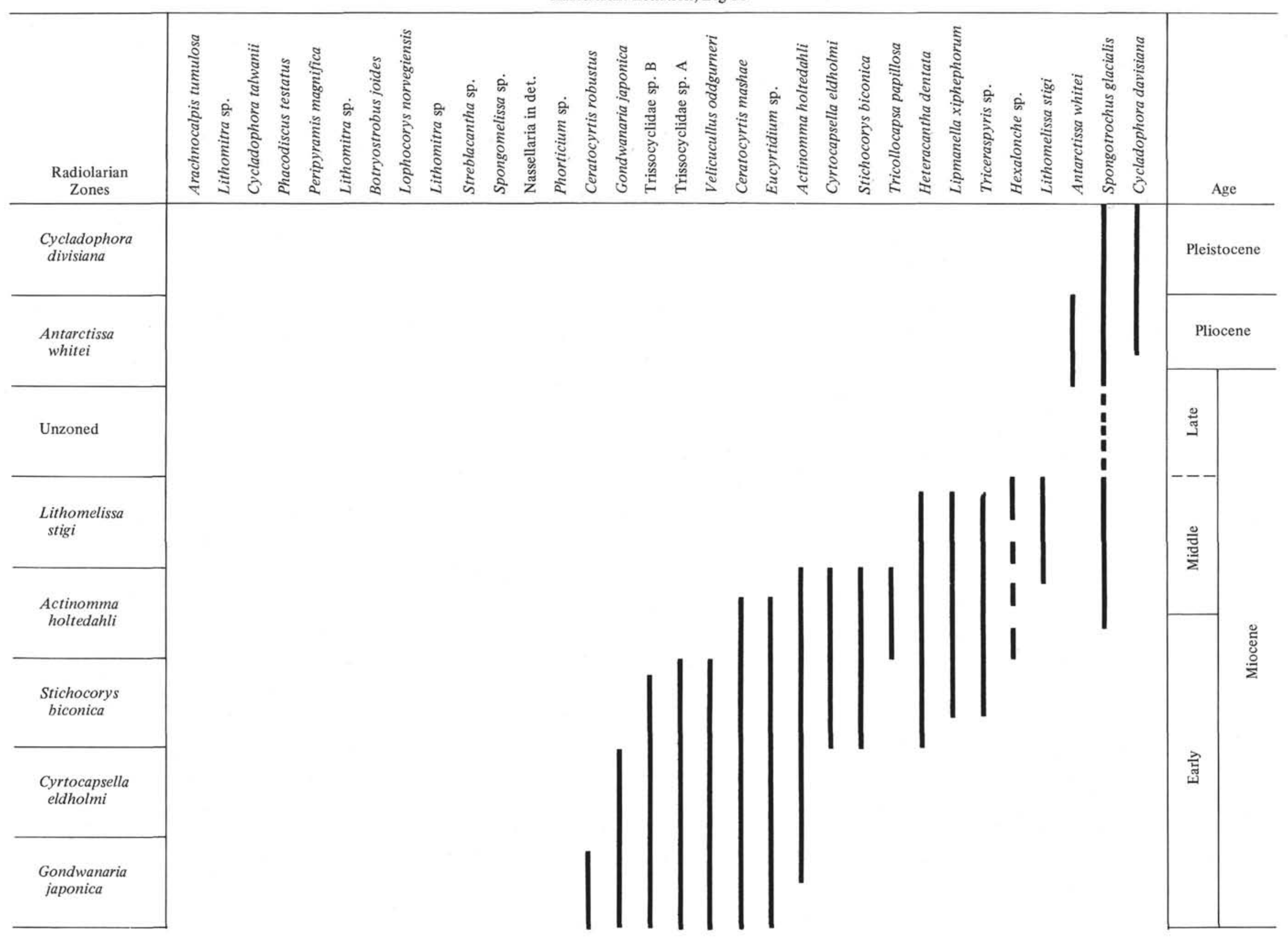




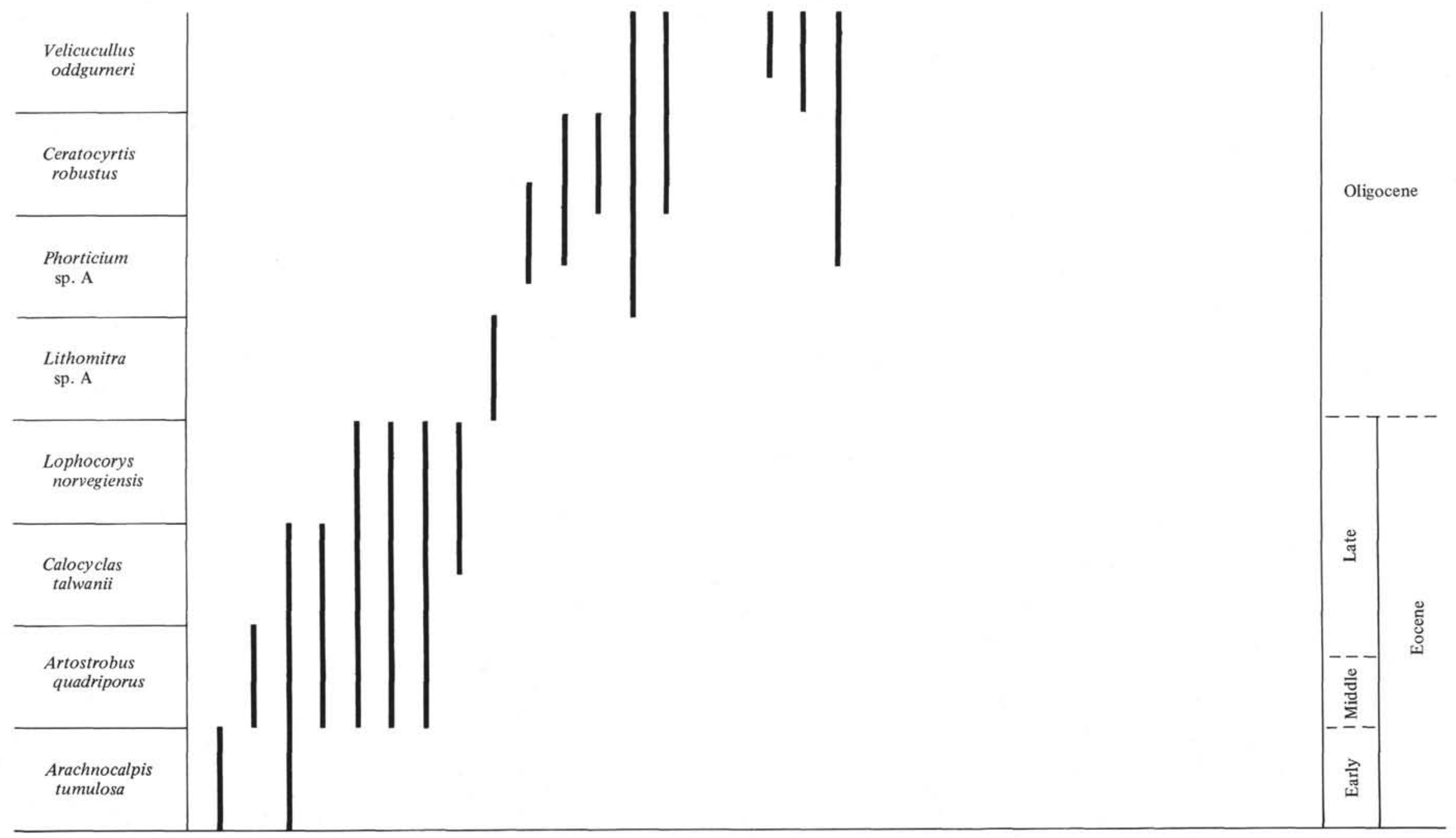


TABLE 24

Alphabetical Listing of Species Encountered in This Study

Actinomma holtedahli n. sp. (Plate 20, Figures 8, 9)

Actinomma sp. (Plate 20, Figure 7)

Actinomma sp. (Plate 19, Figures 1,2)

Amphimelissa setosa (Cleve, 1899) (Plate 11, Figures 28-32)

Androcyclas gamphonycha (Jorgensen, 1900) (Plate 10, Figures 2-6)

Antarctissa whitei n. sp. (Plate 13, Figures 9-14)

Antarctissa sp (Plate 13, Figures 1-8)

Arachnocalpis tumulosa Kozlova, 1966 (Plate 24, Figures 6-9)

Arachnosphaera dichotoma Jorgensen, 1900 (Plate 3, Figures 5-9)

Artobotrys borealis (Cleve, 1899) (Plate 11, Figures 24-27)

Artostrobus annulatus (Bailey, 1856) (Plate 11 Figure 14)

Artostrobus joergenseni Petrushevskaya, 1971 (Plate 11, Figures 12, 13)

Artostrobus quadriporus n. sp. (Plate 23, Figures 15-21)

Botryostrobus sp. (Plate 16, Figures 6-8)

Botryostrobus sp. (Plate 16, Figures 9, 10)

Cadium bullatum Stadum and Ling, 1969 (Plate 18, Figure 15)

Cadium melo (Cleve, 1899) (Plate 12, Figure 14)

Calocyclas extensa (Clark and Campbell, 1942) (Plate 21, Figures 4-7)

Calocyclas talwanii Bjorklund and Kellogg, 1972 (Plate 21, Figures 1-3)

Calocyclas sp. (Plate 21, Figures 8-10)

Calocyclas sp. (Plate 22, Figures 1,2)

Calocyclas sp. (Plate 22, Figures 3, 4)

Calocyclas sp. (Plate 22, Figure 5)

Campylacantha cladophora Jorgensen, 1905 (Plate 6, Figures 1-6)

Ceratocyrtis galeus (Cleve, 1899) (Plate 11, Figures 1-3)

Ceraticyrtis histricosus (Jorgensen, 1905) (Plate 8, Figures 19-24;

Plate 11, Figures 4, 5)

Ceratocyrtis sp. aff. C. histricosus (Jorgensen, 1905) (Plate 15,

Figures 6,7)

Ceratocyrtis mashae n. sp. (Plate 17, Figures 1-5)

Ceratocyrtis robustus n. sp. (Plate 17, Figures 6-10)

Ceratocyrtis sp. (Plate 15, Figures 1-3)

Ceratocyrtis sp. (Plate 18, Figures 18-21)

Ceratospyris hyperborea Jorgensen, 1905 (Plate 10, Figures 13, 14)

Ceratospyris sp. (Plate 23, Figure 22)

Challengeron diodon Haeckel, 1887 (Plate 12, Figures 8-11)

Challengeron (?) spp. (Plate 13, Figures 15-21)

Cladococcus viminalis Haeckel, 1862 (Plate 1, Figures 10-12)

Cladoscenium tricolpium (Haeckel, 1882) (Plate 7, Figures 5-8)

Cornutella sp. aff. C. californica Clark and Campbell, 1942 (Plate 23 , Figures 23, 24)

Cornutella profunda Ehrenberg, 1854 (Plate 11, Figure 15)

Cornutella sp. (Plate 15, Figure 23)

Corocalyptra craspedota (Jorgensen, 1900) (Plate 9, Figures 11-15)

Corocalyptra sp. aff. C. craspedota (Jorgensen, 1900) (Plate 15, Figure 24)

Cromyechinus borealis (Cleve, 1899) (Plate 2 Figures 7-15)

Cytrocapsella eldholmi n. sp. (Plate 17, Figures 11-13)

Cyrtocapsella japonica (Nakaseko, 1963) (Plate 17, Figures 17, 18)

Cyrtocapsella tetrapera Haeckel, 1887 (Plate 17, Figures 19, 20)

Cyrtocapsella sp. (Plate 17, Figures 14-16)

Cycladophora davisiana Ehrenberg, 1872 (Plate 11, Figures 9-10)

Dictyoceras acanthicum Jorgensen, 1900 (Plate 10, Figure 1; Plate 11, Figure 11)

Drymyomma elegans Jorgensen, 1900 (Plate 3, Figures 1-4)

Echinomma leptodermum Jorgensen, 1900 (Plate 1, Figures 13, 14;

Plate 2, Figures 1-6)

Euscenium (?) corynephorum Jorgensen, 1900 (Plate 7, Figures 1-4)

Genus et sp. indet. (Plate 22, Figures 11,12)

Genus et sp. indet. (Plate 24, Figures 1,2)

Gondwanaria japonica (Nakaseko, 1963) (Plate 18, Figures 22-27)

Gonosphaera primordialis Jorgensen, 1905 (Plate 9, Figures 7-10)

Heliodiscus sp. aff. H. hexasteriscus (?) Clark and Campbell, 1942

(Plate 20, Figures 12, 13)

Heliodiscus sp. (Plate 14, Figures 13, 14)

Heteracantha dentata Mast, 1910 (Plate 14, Figures 10-12)

Hexalonche sp. A (Plate 14, Figures 1-5)

Hexalonche sp. B (Plate 14, Figures 7-9)

Hexalonche sp. (Plate 19, Figures 3,4)

Hexaconthium enthacanthum Jorgensen, 1900 (Plate 1, Figures 1-3)
TABLE 24 - Continued

Hexaconthium pachydermum Jorgensen, 1900 (Plate 1, Figures 4-9)

Hexaconthium sp. Pl. 19, Fig. 5

Larcospira minor (Jorgensen, 1900) (Plate 5, Figures 2-8)

Lipmanella xiphephorum sensu Petrushevskaya and Kozlova, 1972 (Plate 16, Figures 11-13)

Litharachnium tenthorium Haeckel, 1862 (Plate 9, Figure 6)

Lithelius spiralis Haeckel, 1860 (Plate 5, Figure 1)

Lithomelissa hystrix Jorgensen, 1900 (Plate 8, Figures 14-18)

Lithomelissa setosa Jorgensen, 1900 (Plate 8, Figures 1-13, Plate 11, Figures 19-23)

Lithomelissa stigi n. sp. (Plate 15, Figures 12-17)

Lithomelissa (?) sp. (Plate 16, Figures 14-16)

Lithomelissa sp. (Plate 15, Figures 9-11)

Lithomitra lineata Ehrenberg, 1838 (Plate 11, Figure 16)

Lithomitra plathycephala (?) (Ehrenberg, 1872) (Plate 11, Figures $17,18)$

Lithomitra sp. (Plate 15, Figures 26-28)

Lithomitra sp. (Plate 23, Figures 1-3)

Lithomitra sp. (Plate 23, Figures 4-6)

Lophocorys biaurita (Ehrenberg, 1875) (Plate 21, Figures 16,17)

Lophocorys norvegiensis Bjorklund and Kellogg, 1972 (Plate 21, Figure 11)

Lophocorys sp. (Plate 21, Figures 12-15)

Lychnocanium grande Clark and Campbell, 1942 (Plate 15, Figure 5)

Lychnocanium (?) sp. (Plate 23, Figures 10,11)

Peridium longispinum Jorgensen, 1900 (Plate 7, Figures 9-15)

Peripyramis magnifica Clark and Campbell, 1942 (Plate 22, Figures 13, 14)

Peripyramis sp. (Plate 18, Figure 1)

Phacodiscus testatus Kozlova, 1966 (Plate 20, Figures 10, 11)

Phormacantha hystrix (Jorgensen, 1900) (Plate 6, Figures 12-18)

Phorticium clevei (Jorgensen, 1900) (Plate 4, Figures 6-10)

Plagiacantha arachnoides (Claparede, 1855) (Plate 6, Figure 7)

Plectacantha oikiskos Jorgensen, 1905 (Plate 6, Figures 8-10)

Plectacantha trichoides Jorgensen, 1905 (Plate 6, Figure 11)

Porospathis holostoma (Cleve, 1899) (Plate 12, Figures 12,13)

Protocystis harstoni (Murray, 1885) (Plate 12, Figures 5-7)

Protocystis tridens (Haeckel, 1887) (Plate 12, Figures 1-3)

Protocystis xiphodon (Haeckel, 1887) (Plate 12, Figure 4)

Pseudodictyophimus gracilipes (Bailey, 1856) (Plate 9, Figures 1-5; Plate 11, Figures 6, 7)

Pseudodictyophimus sp. aff. P. gracilipes (Bailey, 1856) (Plate 16, Figures 1-5)

Pterocyrtidium sp. aff. P. reschetnjakae Petrushevskaya, 1971 (Plate 24, Figures 3-5)

Pylosphaera (?) sp. (Plate 14, Figure 17)

Spongodiscus sp. (Plate 20, Figure 1)

Spongomelissa sp. sensu Chen, 1975 (Plate 22, Figures 6-9)

Spongotrochus glacialis Popofsky, 1908 (Plate 11, Figure 8; Plate 14, Figure 18; Plate 20, Figures 2, 3)

Stichocorys biconica (Vinassa de Regny, 1900) (Plate 16, Figures 17 -21)

Stichocorys seriata (Jorgensen, 1905) (Plate 10, Figures 7-12)

Stichocorys sp. (Plate 18, Figures 2-6)

Streblacantha circumtexta Jorgensen, 1900 (Plate 5, Figures 9-12)

Stylodictya tenuispina Jorgensen, 1900 (Plate 4, Figure 5)

Stylodictya validispina Jorgensen, 1900 (Plate 4, Figure 4)

Stylosphaera sp. (Plate 14, Figures 15, 16)

Theocalyptra tetracantha Bjorklund and Kellogg, 1972 (Plate 22, Figures 15-17)

Tricerospyris sp. (Plate 15, Figures 18-22)

Tricolocapsa papillosa (Ehrenberg, 1872) (Plate 16, Figures 22, 23)

Tripilidium (?) clavipes adven Clark and Campbell, 1942 (Plate 22, Figure 10)

Trissospyris sp. A (Plate 18, Figures 7-11)

Trissospyris sp. B (Plate 18, Figures 12-17)

Velicucullus oddgurneri n. sp. (Plate 19, Figures 6-9)

\section{Suborder NASSELLARIA Ehrenberg (1875)}

\section{Family EUCYRTIDIIDAE Ehrenberg}

Eucyrtidiidae Ehrenberg (1847), Petrushevskaya (1971). 


\section{Genus ARTOSTROBUS Haeckel}

Artostrobus Haeckel 1887; Campbell, 1954; Petrushevskaya, 1975. Petrushevskaya (1975) discusses the lineage of Artostrobus sp. Cr. through $A$. pusillum to $A$. annulatus. Based on her description of $A$. sp. Cr., and the illustration (pl. 10, fig. 1), it is not possible to determine with certainty if $A$. sp. $\mathrm{Cr}$. is identical with the following description.

\section{Artostrobus quadriporus n. sp.}

(Plate 23, Figures 15-21)

Description: Shell consists of cephalis, thorax, and abdomen, with no ring separating the thorax and the abdomen. The 25 specimens examined vary from 40 to $50 \mu \mathrm{m}$ across the thickest part on the abdomen, with a length varying from 90 to $125 \mu \mathrm{m}$. The shell wall is rather thick, and pores on the upper half of the test are round to square, while the test at this part is heavily spiny (Plate 23, Figures 1517 and 20 ). The lower part of the test is characterized by being more delicate, the spines are usually missing. The species name is based on the lowermost rows of pores, which are square, or nearly square (Plate 23, Figures 15, 17, and 20).

Dimensions of holotype: The broadest point on the abdomen is 44 $\mu \mathrm{m}$, while the length of the test is $107 \mu \mathrm{m}$ (Plate 23, Figure 17). Holotype from Sample 339-11, CC.

Distribution: Present at Site 339 throughout the Tertiary sequence. Holotype stored in the type collection at the Zoological Museum, Bergen, with the journal number 57952 .

\section{Family LAMPROMITRIDAE Haeckel, 1881}

\section{Genus CERATOCYRTIS Bütschli}

\section{Ceratocyrtis robustus n. sp.}

(Plate 17, Figures 6-10)

\section{Ceratocyrtis Bütschli, 1882; Petrushevskaya, 1971.}

Description: The test is composed of cephalis and thorax, with the hemispherical, small pored cephalis almost incorporated into the thoracic wall. The apical and ventral spines are normally very short, however, sometimes they might be quite obvious features on the cephalis (Plate 17, Figure 8). The thorax is rather thick walled, with rounded to irregularly rounded pores of variable size, $5-25 \mu \mathrm{m}$. The outline of the thorax is conical, not tapering towards the oral end (Plate 17, Figures 6 and 8 ). The apical spine is a pronounced feature (Plate 17, Figure 10), which, in some cases, branches out and almost reaches the lower end of the thorax. The lateral and dorsal spines do not normally pierce the thoracic wall. If they do, they are very hard to define, due to the rough and spiny upper half of the thorax (Plate 17, Figure 8). This description is based on a study of 25 specimens.

Dimensions of holotype: Cephalis is $43 \mu \mathrm{m}$ wide, and the height about $20 \mu \mathrm{m}$, defined from the top of the cephalis, to where the vertical spine pierces the thoracic wall. The greatest width of the thorax is $166 \mu \mathrm{m}$, while the height of the test (cephalis and thorax) is $127 \mu \mathrm{m}$. Holotype (Plate 17, Figure 8), from Sample 338-17, CC.

The width of the 24 paratypes measured varied between 120 and $180 \mu \mathrm{m}$, with an average of $164 \mu \mathrm{m}$.

Distribution: At Site 338, this species was observed from Samples 21 , CC through 14-2, 140-142 cm, middle Oligocene to lower late Miocene.

The holotype is stored in the type collection in the Zoological Museum, Bergen, with the journal number 57957.

\section{Ceratocyrtis mashae n. sp.}

(Plate 17, Figures 1-5)

Description: This species is very similar to the previous one, differing in having a thorax which is tapering towards the oral end, by the more pronounced incorporation of the cephalis into the thoracic wall, and by its smaller size (cephalis and thorax).

Dimensions of holotype: It is not possible to give exact measurements of the cephalis, due to the heavy ornamentation of the test in the junction area of the cephalis and the thorax. The greatest width of the thorax is $125 \mu \mathrm{m}$, while the length of the test is $160 \mu \mathrm{m}$. Holotype (Plate 17, Figure 1) from Sample 338-11-3, 135-137 cm.

Of the 25 specimens measured, the width of the thorax varied between 112 and $140 \mu \mathrm{m}$, with an average of $128 \mu \mathrm{m}$.

The specific name mashae is in honor of Maria (Masha) G. Petrushevskaya, Zoological Institute, Academy of Sciences, USSR, Leningrad.
Distribution: At Site 338, this species ranges from Samples 23-3, $72-74 \mathrm{~cm}$ through $11-2,115-117 \mathrm{~cm}$, middle Oligocene to lower middle Miocene.

Holotype is stored in the type collection in the Zoological Museum, Bergen, with the journal number 57958.

Remarks: C. mashae was observed in the material examined from Site 116 from the North Atlantic. Petrushevskaya and Kozlova (1972) also reported on a Ceratocyrtis sp. and Ceratocyrtis sp. aff. C. cucullaris (Ehrenberg, 1873). The present author believes that the illustrated specimen in Petrushevskaya and Kozlova (1972, pl. 37, fig. 12) is identical with those specimens the author observed from the Site 116 material, and in many of the Norwegian Sea sites, the species here described as C. mashae.

\section{Genus ANTARCTISSA Petrushevskaya}

\section{Antarctissa whitei n. sp.}

(Plate 13, Figures 9-14)

Antarctissa Petrushevskaya, 1967.

Description: The test is very massive, with no distinct junction of cephalis and thorax. The surface looks rather spongy, and it may appear that the pores look funnel-shaped, although, the general appearance is rounded pores, irregularly displaced, with no obvious difference between the cephalic and thoracic pores (Plate 13, Figures 9-14). The internal structures can be seen by observing from below. From the wall, where cephalis and thorax join, bars pierce out towards the center and join a semicircular ring, situated above the medial bar with the vertical, apical, dorsal, and lateral spines (Plate 13, Figure 13). The bars are seldom visible on the surface of the test.

Dimensions of holotype: The widest point of the test is $67 \mu \mathrm{m}$, while the length is $84 \mu \mathrm{m}$. Twenty-five paratypes were measured varying between 60 and $75 \mu \mathrm{m}$ of the widest part on the test with a length varying between 58 and $100 \mu \mathrm{m}$ (Plate 13, Figure 9). Holotype from Sample 348-6-3, 50-52 cm.

The name whitei is in honor to Dr. Stan M. White, School of Natural Sciences, California State University at Fresno, California, who acted as editorial representative on Leg 38.

Distribution: Present at Sites 341 and 348, ranging from $25, \mathrm{CC}$ to $28-3,79-81 \mathrm{~cm}$, and from $5-5,147-149 \mathrm{~cm}$ to 12, CC, respectively.

The holotype is stored in the type collection at the Zoological Museum, Bergen, with the journal number 57953.

\section{Genus LITHOMELISSA Ehrenberg}

Lithomelissa stigi n. sp.

(Plate 15, Figures 12-17)

\section{Lithomelissa Ehrenberg, 1847.}

Description: Cephalis very small, roughly one-third of the diameter of the thorax, well separated from the latter. Thorax wall campanulate with large rounded pores, 5-8 $\mu \mathrm{m}$, while the pores on the thorax are larger, $5-15 \mu \mathrm{m}$ of a more irregular, rounded shape. The vertical and apical spines are cylindrical and well developed, with a length varying from 10 to $60 \mu \mathrm{m}$ for the apical spine, while the ventral spine is considerably shorter, $5-25 \mu \mathrm{m}$. In most cases, the lateral spines do not pierce the thoracic wall, however, the dorsal spine can be very often seen on the outside of the thoracic wall.

Dimensions of holotype: Width of cephalis, $30 \mu \mathrm{m}$, height of cephalis, $27 \mu \mathrm{m}$, width of thorax, $60 \mu \mathrm{m}$, height of test (cephalis and thorax), $70 \mu \mathrm{m}$, length of apical spine, $40 \mu \mathrm{m}$, and length of vertical spine, $9 \mu \mathrm{m}$. Holotype illustrated on Plate 15, Figure 15. From Sample $338-8-2,120-122 \mathrm{~cm}$. Description is based on examination of 25 specimens.

The name stigi is in honor of my son Stig G. Bjørklund. Holotype is stored in the holotype collection at the Zoological Museum, Bergen, journal number 57955.

\section{Family THEOPERIDAE Haeckel, emend. Riedel 1967}

\section{Genus CYRTOCAPSELLA Haeckel}

\section{Cyrtocapsella eldholmi n. sp.}

(Plate 17, Figures 11-13)

Cyrtocapsella Haeckel, 1887.

Description: This species is the largest Cyrtocapsella species recovered from the Norwegian Sea sediments. Twenty-five specimens were examined with a width of the third segment varying 
between 120 and $150 \mu \mathrm{m}$, and a height of the three first segments varying between 130 and $160 \mu \mathrm{m}$. Cephalis is spherical, furnished with a well-developed apical spine (Plate 17, Figure 11). Thorax is widely campanulated with rounded pores, 5-10 $\mu \mathrm{m}$, equally distributed, thorax wall thick.

The abdominal, third, segment is separated from the thorax with a well-defined lumbar stricture. The third segment is thick walled with the same pore ornamentation as on the thorax. The abdominal fourth segment, when present, is characterized by its thinner wall and its variable outline, with the two extreme forms shown on Plate 17, Figures 11, 12, between which a series of intermediates exists.

Dimensions of holotype: Width and height of cephalis are equal, $30 \mu \mathrm{m}$. Width and height of thorax are $105 \mu \mathrm{m}$ and $60 \mu \mathrm{m}$, respectively. Width and height of the third segment are $133 \mu \mathrm{m}$ and $63 \mu \mathrm{m}$, respectively. The apical spine, $23 \mu \mathrm{m}$, and the vertical spine, $13 \mu \mathrm{m}$. Holotype (Plate 17, Figure 11) from Sample 338-12-2, 145-147 cm.

The specific name eldholmi is in honor of Associate Professor Olav Eldholm, Geological Institute, University of Oslo, who has extensively studied the evolution and the spreading of the NorwegianGreenland Seas. The holotype is stored in the holotype collection at the Zoological Museum, Bergen, with the journal number 57956.

Remarks: This species is so outstanding both in size and structure, that it should be easy to distinguish from the other Cyrtocapsella species (Plate 17, Figures 14-20), present in Norwegian Sea and North Atlantic Ocean sediments.

\section{Family SETHOPHORMIDAE Haeckel, 1882}

Genus VELICUCULLUS Riedel and Campbell, 1952

Velicucullus oddgurneri $\mathbf{n}$. sp. (Plate 19, Figures 6-9)

Definition: The genus is characteristic by its velum on the underside of the flatly expanded or almost discoidal thorax. Because of the great size of this species, and the flat thorax, it is rather difficult to turn the specimens when mounted on the slide and almost all observations were, on the 25 specimens examined, from the apical side. It was, therefore, not possible to observe the velum in side view. There is a shadow of a ring located on the thorax where the thorax wall starts to flatten out. As there is no stricture in this position, this shadow is taken for being the velum (Plate 19, Figures 6-8).

For internal structures, the medial bar with the axial, dorsal, ventral, and lateral bars are recognized. The normal pattern is that these bars are perpendicular to each other (Plate 19, Figure 6). The dorsal spine, however, does, in some cases, furcate so it looks as if five spines are present (Figure 18). In some cases, the spines penetrate the thoracic wall, so they can be seen on the outside. The diameter of the outer edge of the flattened thorax varies between 350 and $450 \mu \mathrm{m}$, while the diameter of what is believed to be the velum varies between 180 and $230 \mu \mathrm{m}$. The pores on the thorax are irregularly rounded, with an almost uniform size, $8-10 \mu \mathrm{m}$, showing a tendency to linear orientation towards the rim (Plate 19, Figure 8).

Dimensions of holotype: Diameter of velum, $210 \mu \mathrm{m}$, diameter of the outer rim of thorax, $360 \mu \mathrm{m}$. Holotype (Plate 19, Figure 6), from Sample 338-12, CC.

The specific name oddgurneri is in honor of my father Odd Gurner Bj申rklund, who has shown much interest in my work.

The holotype is stored in the type collection of the Zoological Museum, Bergen, with the journal number 57954 .

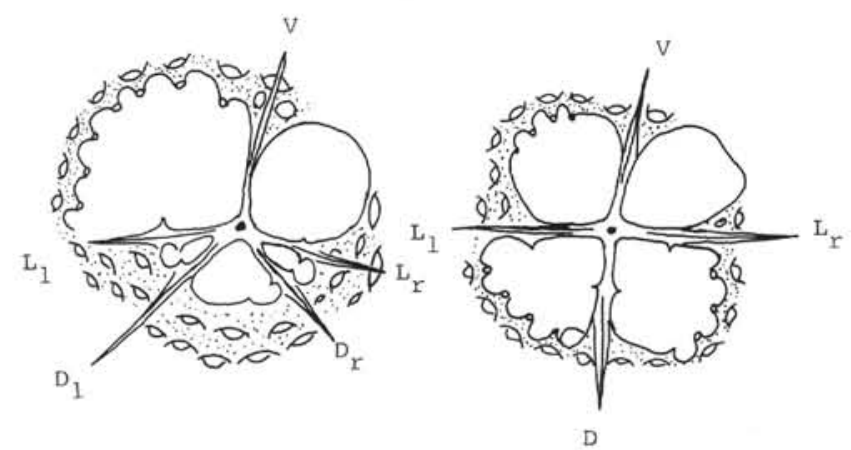

Figure 18. Internal view of the main spines in Velicucullus oddgurneri seen from the apical side. $V=$ ventral spine,

$$
\begin{aligned}
& D=\text { dorsal spine, } L=\text { lateral spine, } \text { l and } r \text { refer to left and } \\
& \text { right, respectively. }
\end{aligned}
$$

\section{ACKNOWLEDGMENTS}

I am very grateful to all Leg $38 \mathrm{crew}$ members and the scientific staff for good cooperation during the leg and for valuable information and discussions gained during the paleo meeting in Frankfurt, and the postcruise meeting at LamontDoherty Geological Observatory.

The laboratory technician, Mr. Johan Lund, deserves a special thanks for not making too many objections when I was spreading out my DSDP material in the laboratory. My sincere thanks also go to Mrs. Astrid Dundas and Mrs. Solveig Moklev for typing the manuscript.

Financial support for this work was sponsored by the Norwegian Research Council for Science and the Humanities, Grant D. 41.31-19.

\section{REFERENCES}

Bailey, J.W., 1856. Notice of microscopic forms found in the soundings of the sea of Kamtschatka: Am. J. Sci. Arts, ser. 2, p. 22.

Benson, R.N., 1972. Radiolaria, Leg 12, Deep Sea Drilling Project. In Laughton, A.S., Berggren, W.A., et al., Initial Reports of the Deep Sea Drilling Project, Volume 12: Washington (U.S. Government Printing Office), p. 10851113.

Bj申rklund, K.R. and Kellogg, D.E., 1972. Five new Eocene radiolarian species from the Norwegian Sea: Micropaleontology, v. 18 , p. $386-396$.

Borisenko, N.I., 1960a. New Radiolarians from the Paleocene deposits of the Kubanj: All Union Scientific Research Institute for Oil and Gas, Trans., no. 4, p. 199207.

1960b. The Radiolarians of the lower and middle Eocene of Western Kubanj: All Union Scientific Research Institute for Oil and Gas, Trans., no. 4, p. 219 231. (Translated by E.M. Roden in collaboration with W.R. Riedel, National Science Foundation Grant GN687.)

Bütschli, O., 1882. Beitrage zur Kenntnis der Radiolarienskelette, insbesondere der Cyrtida: Z. Wiss. Zool., v. 36, p. 485-540.

Campbell, A.S., 1954. Radiolaria. In Moore, R.C. (Ed.), Treatise on invertebrate paleontology: Kansas (Univ. Kansas Press and Geol. Soc. Am) Pt. D, Protista 3, p. 11163.

Chen, P.-H., 1975. Antarctic Radiolaria. In Hayes, D.E., Frakes, L.A., et al., Initial Reports of the Deep Sea Drilling Project, Volume 28: Washington (U.S. Government Printing Office), p. 437-513.

Cita, M.B., Nigrini, C., and Gartner, S., 1970. Biostratigraphy. In Peterson, M.N.A., Edgar, N.T., et al., Initial Reports of the Deep Sea Drilling Project, Volume 2: Washington (U.S. Government Printing Office), p. 391411.

Claparéde, E., 1855. Uber die Lebenserscheinungen und insbesondere Bewegungserscheinungen der Acanthometren: Monatsber. Kgl. Preuss. Akad. Wiss. Berlin, p. 674-676.

Clark, B.L. and Campbell, A.S., 1942. Eocene radiolarian faunas from the Mt. Diablo area, California: Geol. Soc. Am. Spec. Paper 39, p. 1-112.

Cleve, P.T., 1899. Plankton collected by the Swedish Expedition to Spitzbergen in 1898: K. Svenska Vetensk. Akad. Handl. v. 32, p. 1-51.

Dumitrica, P., 1972. Siliceous microfossils, Leg 13 of the Deep Sea Drilling Project. In Ryan, W.B.F., Hsü, K.H., et al., Initial Reports of the Deep Sea Drilling Project, 
Volume 13: Washington (U.S. Government Printing Office), p. 829-969.

Ehrenberg, C.G., 1838. Uber die Bildung der Kreidefelsen und des Kreidemergels durch unsichtbare Organismen: Abhandl. Preuss. Akad. Wiss. Jahrg. 1838. 1847. Uber eine halibiolithische, von Herrn $R$. Schomburgk entdeckte, vorherrschend aus mikroskopischen Polycystinen gebildete, Gebirgsmasse von Barbados: Monatsber. Kgl. Preuss. Akad. Wiss. Berlin, Jahrg. 1846 , p. $382-385$.

1854. Mikrogeologie: Leipzig (Forsetzung), 1856.

, 1872. Mikrogeologischen Studien über das kleinste Leben der Meeres-Tiefgrunde aller Zonen und dessen geologischen Einfluss: Abhandl. Kgl. Akad. Wiss. Berlin, Jahrg. 1872, p. 131-399.

, 1873. Grössere Felsproben des PolycystinenMergens von Barbados mit weiteren Erlauterungen: Monatsber. Kgl. Preuss. Akad. Wiss. Berlin, Jahrg. 1873, p. 213-263.

1875. Fortsetzung der mikrogeologischen Studien als Gesammt-übersicht der mikroskopischen Paläontologie gleichartig analysirter Gebrgsarten der Erde, mit specieller Rucksicht auf den Polycystinen-Mergel von Barbados: Abhandl. Kgl. Preuss. Akad. Wiss. Berlin, Jahrg. 1875 , p. $1-226$.

Goll, R.M., 1972. Leg 9 Synthesis, Radiolaria. In Hays, J.D. et al., Initial Reports of the Deep Sea Drilling Project, Volume 9: Washington (U.S. Government Printing Office), p. 947-1058.

Goll, R.M. and Bjфrklund, K.R., in press. Preservation of Radiolaria in modern Atlantic sediments.

Grundow, A., 1884. Die diatomeen von Franz-Josefs-Land: Denkschrift. math.-naturw. Class Kaiserl. Akad. Wissen schft., v. 48, p. 53-112.

Haeckel, E., 1860. Abbildungen und Diagnosen neuer Gattungen und Arten von lebenden Radiolarien des Mittelmeeres: Monatsber. $\mathrm{Kgl}$. Preuss. Akad. Wiss. Berlin, Jahrg. 1860, p. 835-845.

1862. Die Radiolarien (Rhizopoda Radiaria). Eine Monographie: Berlin (Reimer), xiv $+572 \mathrm{pp}$.

1881. Produmus systematic Radiolarium. Entwurf eines Radiolarien-Systems auf grund von studien der Challenger-Radiolarien, Jena: Z. Naturw., v. 15, (n. ser. v. 8 , no. 3 ), p. $418-472$.

1882. Prodromus Systematic Radiolarium. Entwurf eines Radiolarien-Systems auf Grund von Studien der Challenger-Radiolarien: Jena. Zr. Naturwiss., v. 8 , p. $418-472$.

1887. Report on the Radiolaria collected by H.M.S. Challenger during the years 1873-1876. Rept. Sci. Res. Voyage Challenger. 1873-1876, Edinburgh, Zool., t. XVIII, Pt. I, II.

Heiberg, P.A.C., 1863. Conspectus criticus diatomacearum Danicarum: Kjobenhavm (Wilhelm Priors Ferlag), p. 1136.

Hustedt, ., 1935. (Reprint 1962). Die Kieselalgen Deutschlands, Osterreichs und der Schweiz unter Berüchsichtigung der übrigen Länder Europas sowie der angranzenden Meeresgebiete, In Rabenhorst, L. (Ed.), Kryptogamenflora von Deutschland, Osterreich und der Schweiz: v. 7, p. 920

J $\phi$ rgensen, E., 1900. Protophyten und Protozoën in plankton aus der norwegischen Westküste: Bergens Mus. Årb., 1899 , p. 51-95.

, 1905. The protist plankton and the diatoms in bottom samples: Bergens Mus. Skr., p. 49-151, 195-225.

Kling, S.A., 1973. Radiolaria from the eastern North Pacific Deep Sea Drilling Project, Leg 18. In Kulm, L.D., von Huene, R., et al., Initial Reports of the Deep Sea Drilling
Project, Volume 18: Washington (U.S. Government Printing Office), p. 617-671.

Kozlova, G.E. and Gorbovets, A.N., 1966. Radiolarii verkhnemelovykh i verkhne-eozenovykh otlozhenii Zapadno-Sibirskoi nizmennosti, nedra: Vses. Neft. Nauchno-issled. Geol.-Razu Inst., no. 248, p. 159.

Krasheninnikov, A.V., 1960. Some Radiolarians of the Lower and Middle Eocene of the Western Pre-Caucasus. In Sazonov, N.T. and Shchutskaya, E.K. All Union Petroleum Scientific Research Institute for Geological Survey. Trans., no. 16, p. 271-301. (Translated by E.M. Roden in collaboration with W.R. Riedel, National Science Foundation Grant GN-687.)

Lipman, R.Kh., 1950. The radiolarians of the Eocene of Kyzyl-Kumov: All Union Geological Scientific Research Institute, Trans. no. 1, p. 51-65. (Translation made by E.M. Roden, in collaboration with W.R. Riedel, National Science Foundation Grant GN-687.)

Mast, H., 1910. Die Astrosphoeriden: Wiss. Ergebn. der Deutschen Tiefsee-Expedition auf dem Dampfer "Valdivia" 1898-1899, v. 19, p. 125-190.

Moore, T.G., 1971. Radiolaria. In Tracey, J.I., Jr., Sutton, G.H., et al., Initial Reports of the Deep Sea Drilling Project, Volume 8: Washington (U.S. Government Printing Office), p. 391-411.

Nakaseko, K., 1963. Neogene Cyrtoidea (Radiolaria) from the Isozaki Formation in Ibaraki Prefecture, Japan: Sci. Repts., Osaka Univ., v. 12, p. 165-198.

Perch-Nielsen, K., 1975. Microfossil of unknown affinity from DSDP 29-280A-22, CC. In Kennett, J.P., Houtz, R.E., et al., Initial Reports of the Deep Sea Drilling Project, Volume 29: Washington (U.S. Government Printing Office), p. 909-912.

Petrushevskaya, M.G., 1967. Radiolarii otryadov Spumellaria i Nasselaria Antarkticheskoi oblasti (po materialam Sovetskoi Antarkticheskoi ekspeditsii). Issled. fauny morei, t. IV (XII). Resultaty biol. issled: Sovetskoi Antarkticheskoi Ekspeditsii (1950-1958), v. 3, p. 5-186.

1969. Raspredelenie skeletov radiolarii y osadkakh severnoi Atlantiki. Sb. "Drevnie i sovremennye radiolarii": Izd. Lvovsk. Gos un-ta, Lvov. 1971. Radiolarii Nassellaria y planktone Mirovogo Okeana: Issled. fauny morey, Leningrad.

, 1975. Cenozoic radiolarians of the Antarctic, Leg 29, DSDP. In Kennett, J.P., Houtz, R.E., et al., Initial Reports of the Deep Sea Drilling Project, Volume 29: Washington (U.S. Government Printing Office), p. 541675.

Petrushevskaya, M.G. and Bj申rklund, K.R., 1974. Radiolarians in Holocene sediments of the NorwegianGreenland Seas: Sarsia, v. 57, p. 33-46.

Petrushevskaya, M. and Kozlova, G., 1972. Radiolaria: Leg 14, Deep Sea Drilling Project. In Hayes, D.E., Initial Reports of the Deep Sea Drilling Project, Volume 14: Washington (U.S. Government Printing Office), p. 459648.

Pickett, J. and Scheibnerová, V., 1974. The inorganic origin of "anellotubulates": Micropaleontology, v. 20, p. 97102.

Popofsky, A., 1908. Die Radiolarien der Antarktis: Dt. Südpol. Exped. Zool., v. 10, p. 185-308.

Richardson, G., Gregory, D., and Polland, J., 1973. A nellotubulates are manufactured "microfossils": Nature, v. 246 , p. $347-348$.

Riedel, W.R., 1967. Class Actinopoda. In The fossil record: London (Geol. Soc. London).

Riedel, W.R. and Campbell, A.S., 1952. A new Eocene radiolarian genus: J. Paleontol. v. 26, p. 667-669. 
Riedel, W.R. and Sanfilippo, A., 1970. Radiolaria. In Bader, R.G., Gerard, R.D., et al., Initial Reports of the Deep Sea Drilling Project, Volume 4: Washington, (U.S. Government Printing Office), p. 503-575.

1971. Radiolaria. In Winterer, E.L., Riedel, W. R., et al., Initial Reports of the Deep Sea Drilling Project, Volume 7: Washington (U.S. Government Printing Office), p. 1529-1672.

Ruddiman, W.F. and McIntyre, A., 1973. Time-transgressive deglaciation retreat of polar waters from the North Atlantic: Quat. Res., v. 3, p. 117-130.

Sanfilippo, A. and Riedel, W.R., 1973. Cenozoic Radiolaria (exclusive of Theoperids, Artostrobiids and Amphypyndacids) from the Gulf of Mexico, Deep-Sea Drilling Project, Leg 10. In Worzel, J.L., Bryant, W., et al., Initial Reports of the Deep Sea Drilling Project, Volume 10:
Washington (U.S. Government Printing Office), p. 475611.

Schulz, P., 1927. Diatomeen aus nord deutschen Basaltuffen und Tuffgeschieben: $Z$. Geschiebeforschung, v. 3, p. 6678, 113-126.

Stadum, C. and Ling, H.Y., 1969. Tripylean Radiolaria in deep-sea sediments of the Norwegian Sea: Micropaleontology, v. 15, p. 281-289.

Talwani, M. and Eldholm, O., 1972. Continental margin off Norway: A geophysical study: Geol. Soc. Am. Bull., v. 83, p. $3575-3606$.

Vinassa de Regny, P.E., 1900. Radiolari Miocenici Italiani: Mem. R. Accad. Sci. 1st Bologna: ser. 5, 8, p. 565-595.

Wetzel, O., 1935. Die Mikropaläontologie des Heiligenhafener Kieseltones (Ober-Eozän): Jahr. Niedersächs. Geol. Vereinigung, v. 27, p. 41-75. 



\section{SPECIFIC NOTES CONCERNING THE PLATES}

"Glacial" sediments, relatively rich in radiolarians, were recovered from several sites (Table 4). Site 349 is especially rich in radiolarians, and the faunal assemblage recovered from Sample 349-1-1, 10-12 cm is identical with the faunal assemblages obtained from gravity cores from the same area. Instead of illustrating species from Sample 349-1-1, 10-12 cm, the author has chosen to show photographs of species photographed from the radiolarian collection of J $\phi$ rgensen, which is stored at the Zoological Museum, Bergen. As J $\phi$ rgensen did not use any photographs in his publications, and as he described quite a number of new species, it is in the interest of all radiolarian taxonomists to have access to this type of material. J $\phi$ rgensen did not mark his holotypes, but the illustrated specimens on Plates 1-10 have been identified by J $\phi$ rgensen. Plate 11 illustrates specimens recovered from Sample 349-1-1, 10-12 cm, while the phaeodarians shown on Plate 12 are taken from the J $\phi$ rgensen and Cleve collections. All specimens illustrated from the J $\phi$ rgensen collection include in their captions, the sampling locality (not very well defined, only to the specific fjord), and a number (example, $1 / 41900$ ) referring to day, month, and year of sampling. More species are illustrated than shown in Table 4, thus making the J $\phi$ rgensen collection more complete and valuable for future taxonomic work.

\section{PLATE 1}

Scale bar is $100 \mu \mathrm{m}$

Figures 1-3 Hexaconthium enthacanthum J $\phi$ rgensen, 1900.

1. Herdlafjorden 20/1-1899.

2,3. Herdlafjorden 24/1-1899.

Figures 4-9 Hexaconthium pachydermum $\mathrm{J} \phi$ rgensen, 1900.

4, 5. Same specimen, Kvaenangen 24/1-1899.

6, 7. Same specimen, Kvaenangen 24/1-1899.

8, 9. Herdlafjorden 20/1-1899 and 29/8-1899, respectively.

Figures 10-12 Cladococcus viminalis Haeckel, 1862.

10. Storfjorden 1900.

11. Romereimsfjorden 8/9-1901.

12. Herdlafjorden 20/1-1899.

Figures 13, 14 Echinomma leptodermum J $\phi$ rgensen, 1900. Both from Kvaenangen 24/1-1899. 
PLATE 1
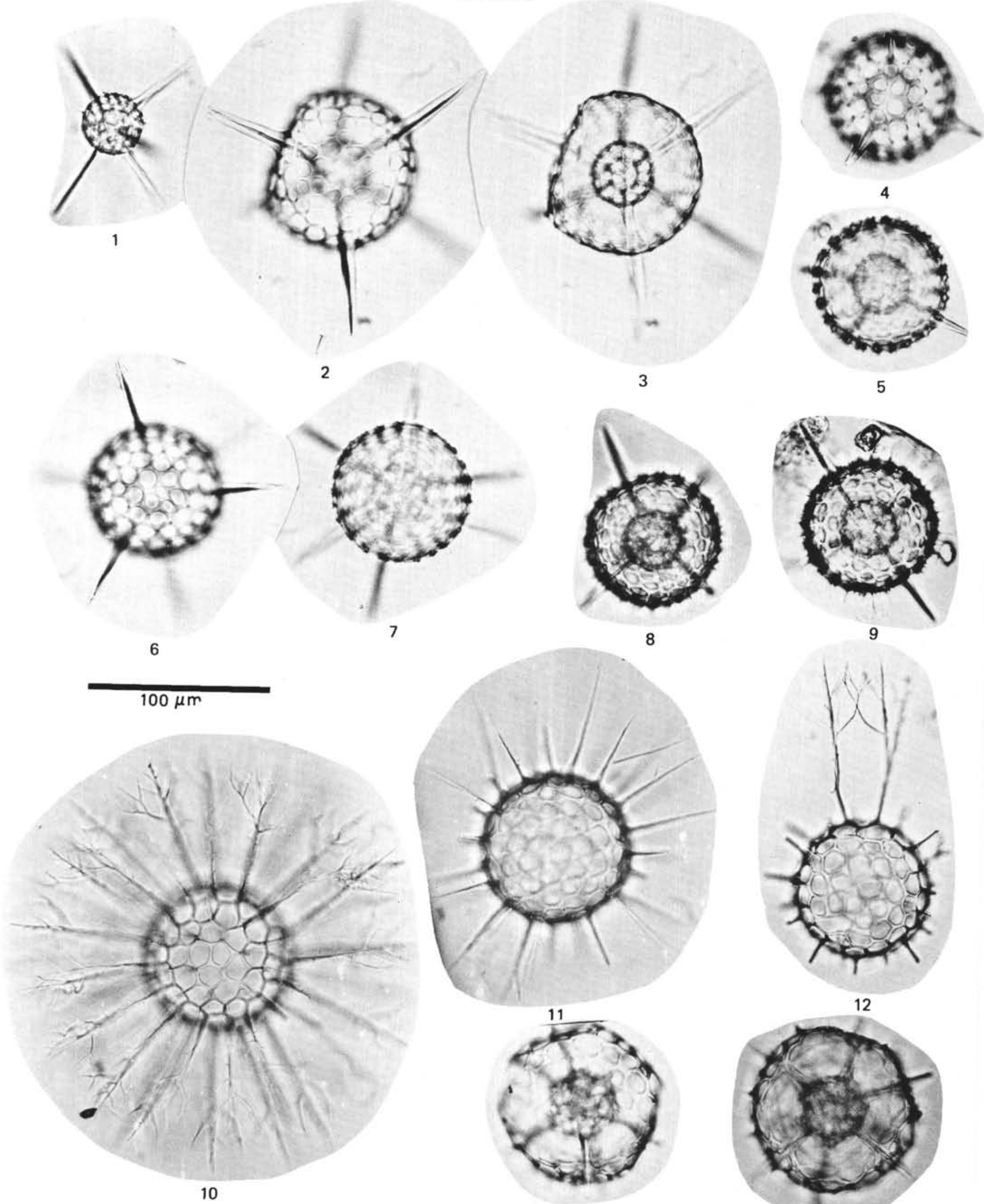

13

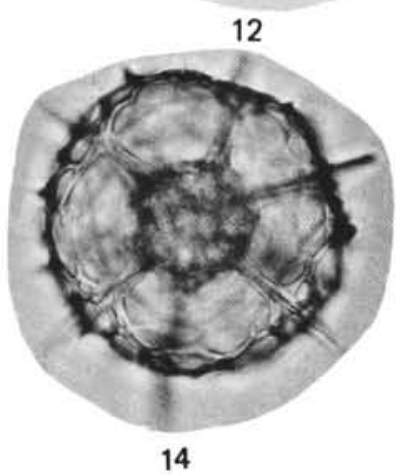


PLATE 2

Scale bar is $100 \mu \mathrm{m}$

Figures 1-6 Echinomma leptodermum J $\varnothing$ rgensen, 1900.

1, 2. Same specimen Kvaenangen 24/1-1899.

3, 4. Same specimen Kvaenangen 24/1-1899.

5. Helligvaer 12/1-1899.

6. Michal Sars st. no. 2, 2/2-1901.

Figures 7-15 Cromyechinus borealis (Cleve, 1899).

7, 8. Vestfjorden 1/2-1899.

9. Helligvaer 12/1-1899.

10. Senja 21/1-1899.

11, 12. Vestfjorden 1/2-1899.

13, 14. Vesteralen 19/1-1899.

15. Vesterålen 22/3-1899.

\section{PLATE 3}

Scale bar is $100 \mu \mathrm{m}$

Figures 1-4 Drymyomma elegans J $\phi$ rgensen, 1900.

1, 2. Senja 21/1-1899.

3,4 . Vesteralen 19/1-1899.

Figures 5-9 Arachnosphaera dichotoma J $\phi$ rgensen, 1900.

5. Herdlafjorden 20/1-1899.

6-9. Herdlafjorden 28/2-1899.

Figures 10-16 Rhizoplegma boreale (Cleve, 1899).

10-14. Vesterålen 19/1-1899.

15, 16. Raftsund 3/2-1899.

(see page 1134)

\section{PLATE 4}

Scale bar is $100 \mu \mathrm{m}$

Figures 1-3 Rhizoplegma boreale (Cleve, 1899).

1. Helligvaer $12 / 1-1899$.

2, 3. Vesteralen 19/1-1899.

Figure $4 \quad$ Stylodictya validispina J $\phi$ rgensen, 1900. Vesteralen 22/3-1899.

Figure $5 \quad$ Stylodictya tenuispina J $\phi$ rgensen, 1900. Vesteralen 22/3-1899.

Figures 6-10 Phorticium clevei (J $\phi$ rgensen, 1900).

6,7 . Vestfjorden $1 / 2-1899$.

8, 9. Herdlafjorden 20/1-1899.

10. Byfjorden 21/2-1899.

(see page 1135) 
PLATE 2
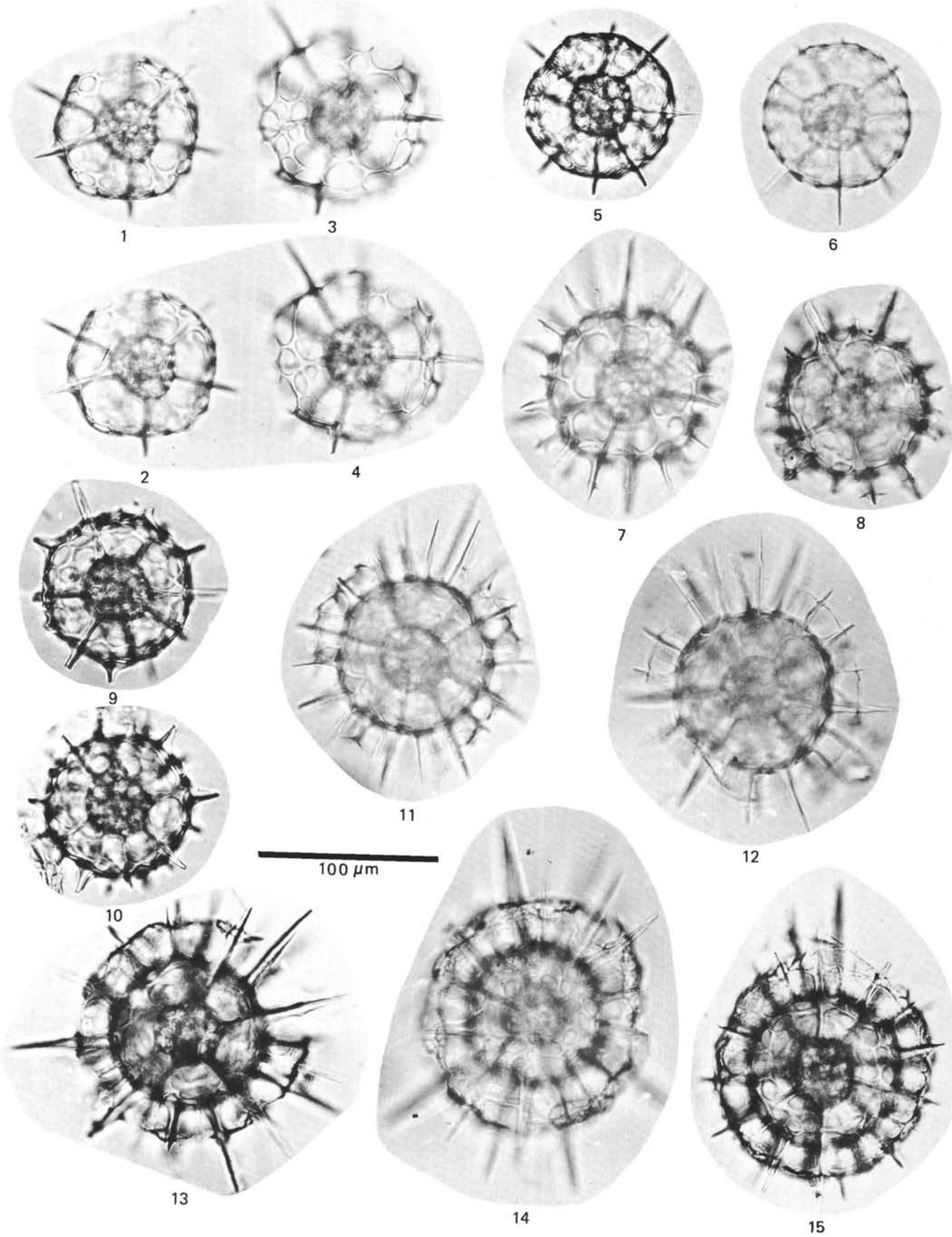
PLATE 3

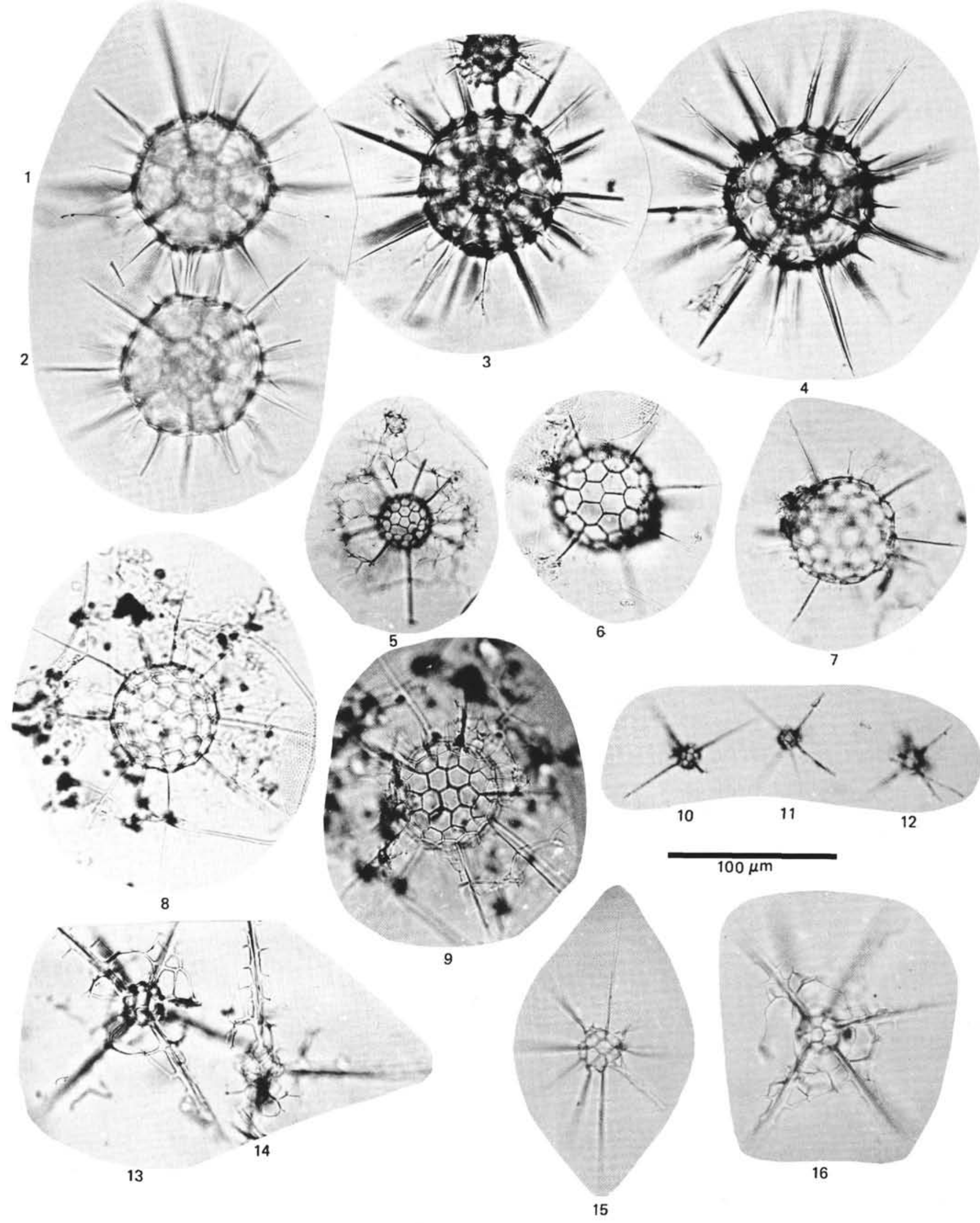


Plate 4
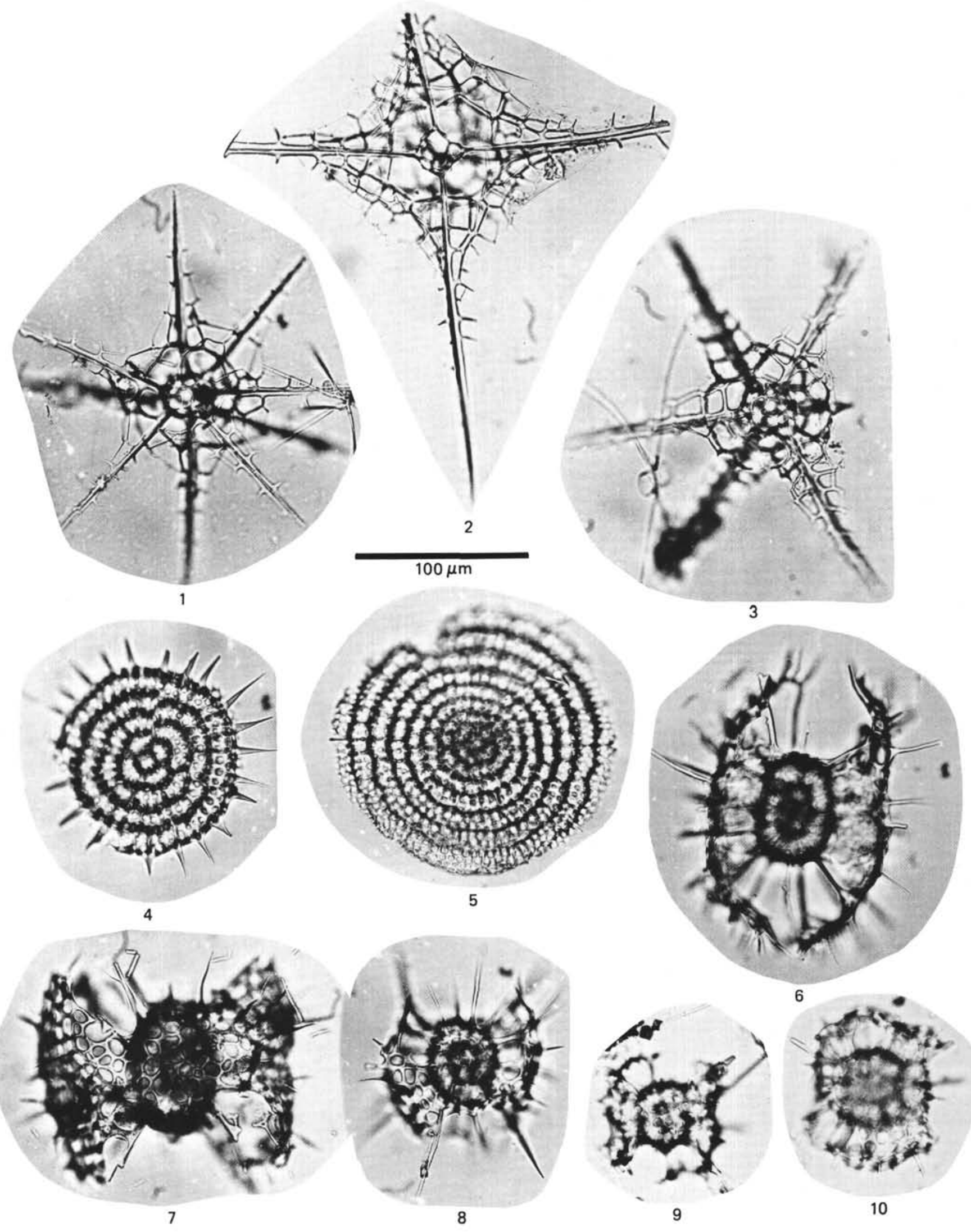


\author{
PLATE 5 \\ Scale bar is $100 \mu \mathrm{m}$ \\ Figure $1 \quad$ Lithelius spiralis Haeckel, 1860. \\ Vesteralen 19/1-1899. \\ Figures 2-8 Larcospira minor (J $\phi$ rgensen, 1900). \\ 2-4. Herdlafjorden 28/2-1899. \\ 5-7. Vesterålen 19/1-1899. \\ 8. Vestfjorden 1/2-1899. \\ Figures 9-12 Streblacantha circumtexta (J $\phi$ rgensen, 1900). \\ 9, 10, 12. Vestfjorden 1/2-1899. \\ 11. Tysfjorden $28 / 2-1899$.
}

\title{
PLATE 6
}

Scale bar is $100 \mu \mathrm{m}$

Figures 1-6 Campylacantha cladophora J $\phi$ rgensen, 1905.

All from Kvaenangen 24/1-1899.

Figure $7 \quad$ Plagiacantha arachnoides (Claparede, 1855). Herdlafjorden 28/2-1899.

Figures 8-10 Plectacantha oikiskos J $\phi$ rgensen, 1905.

8. Senja 21/1-1899.

9. Helligvaer 12/1-1899.

10. Herdlafjorden 28/2-1899.

Figure $11 \quad$ Plectacantha trichoides J $\phi$ rgensen, 1905. Herdlafjorden 28/2-1899.

Figures 12-18 Phormacantha hystrix (J $\phi$ rgensen, 1900).

12-17. Same specimen; all from Vestfjorden 1/21899.

18. Vesteralen 19/1-1899. 
PLATE 5

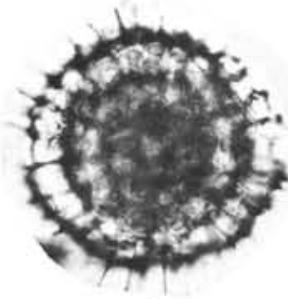

1
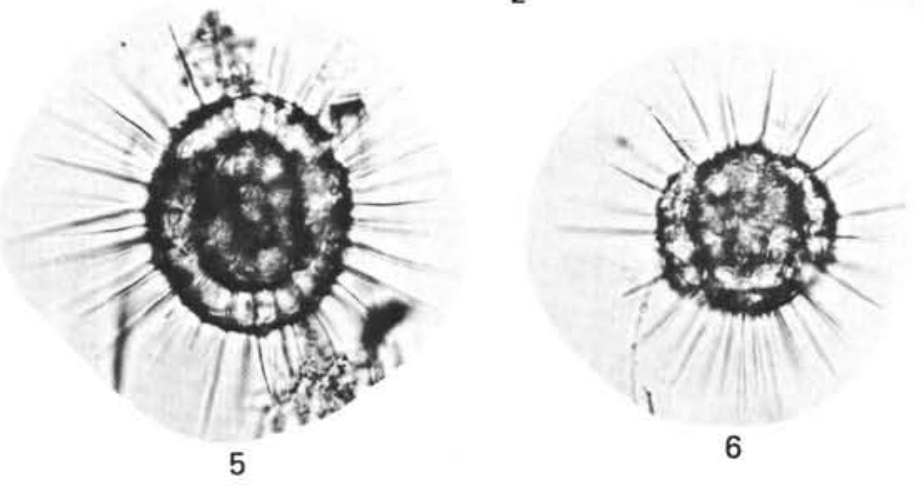

3

$100 \mu \mathrm{m}$
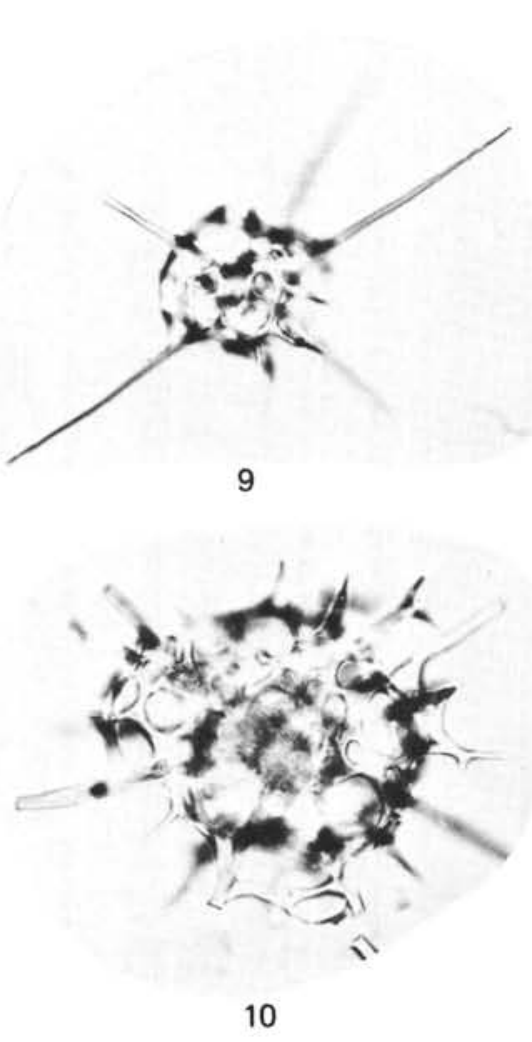

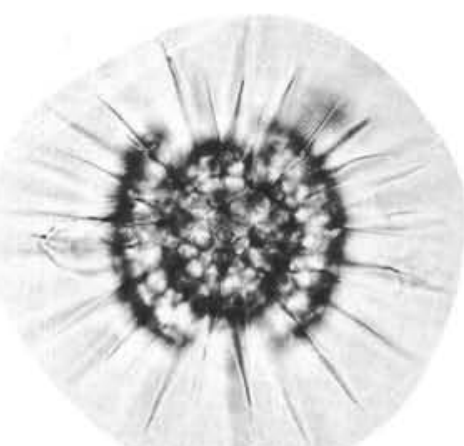

4

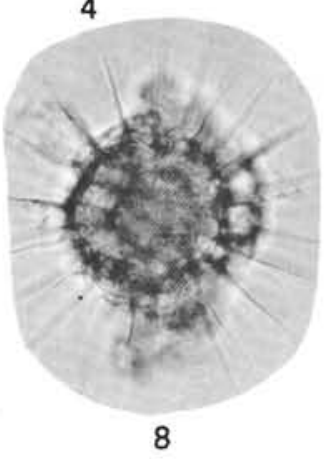

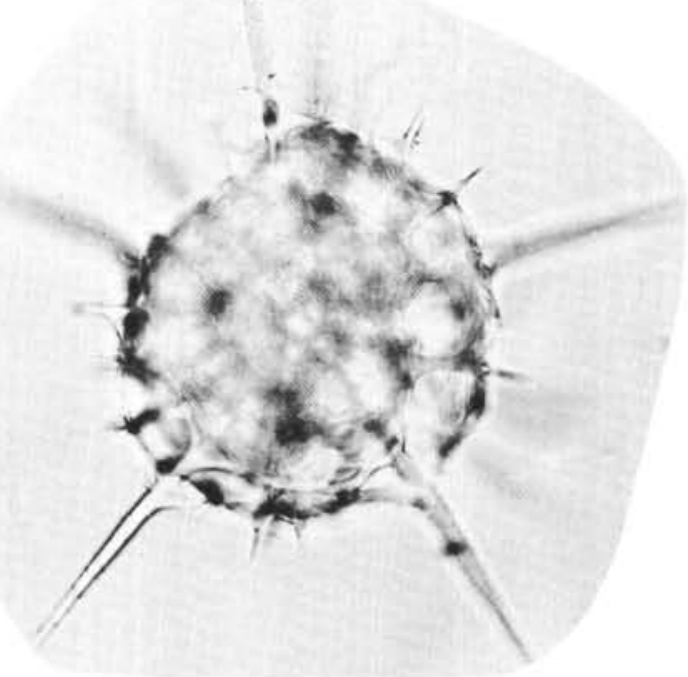

11

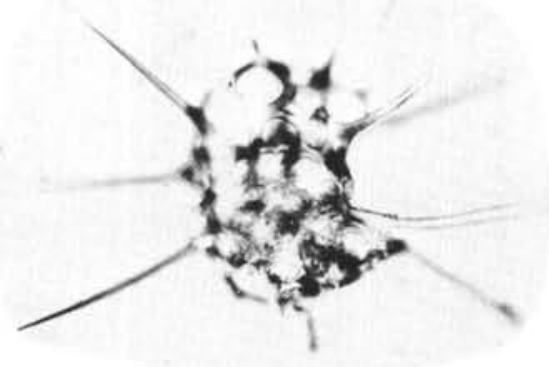

12 
PLATE 6

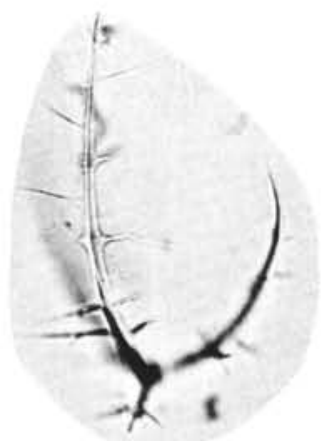

1

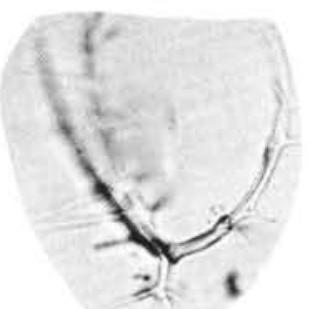

2
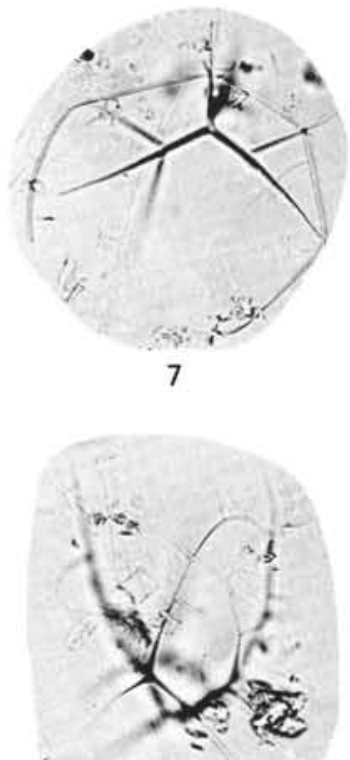

है

11

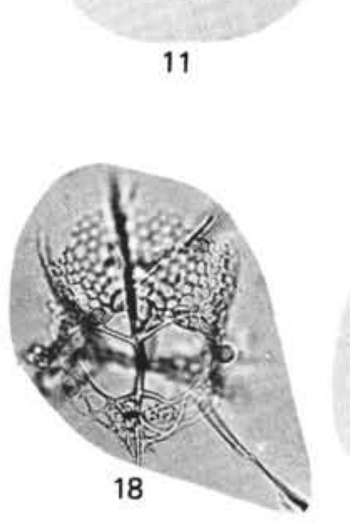

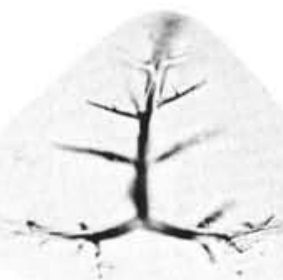

3

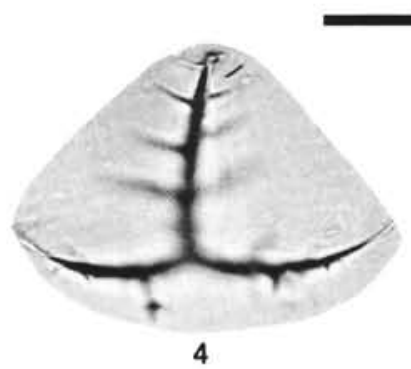

$100 \mu \mathrm{m}$

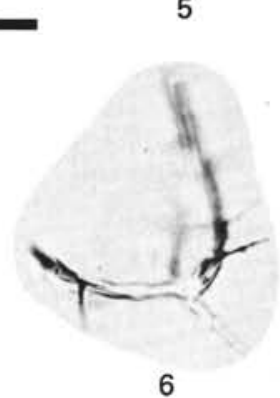

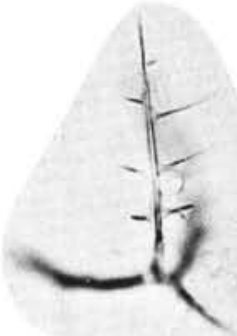

5

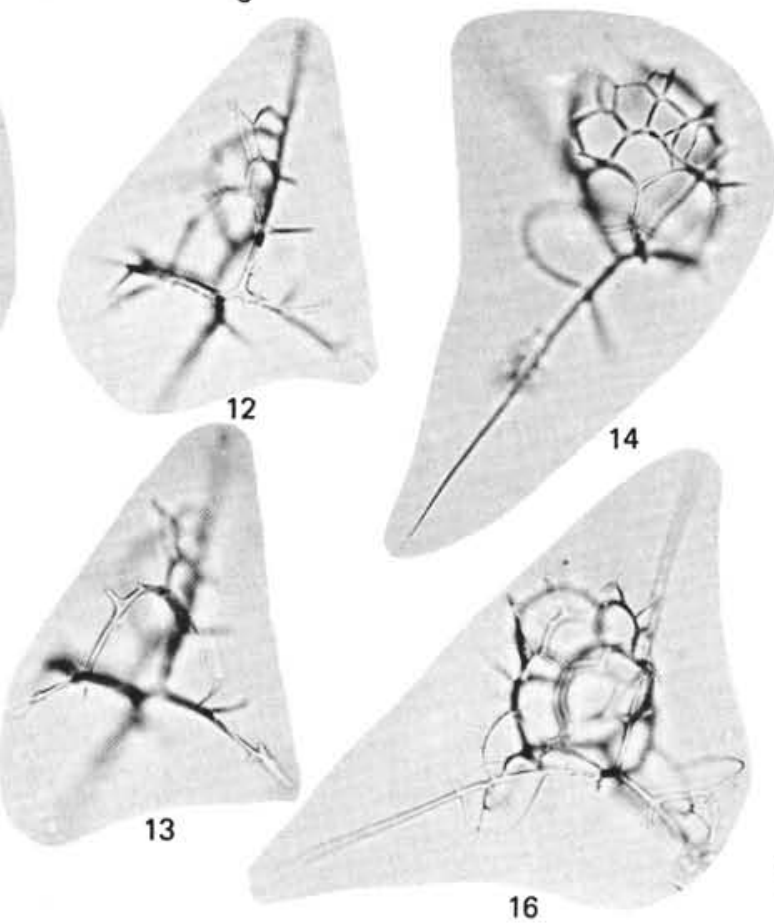

13
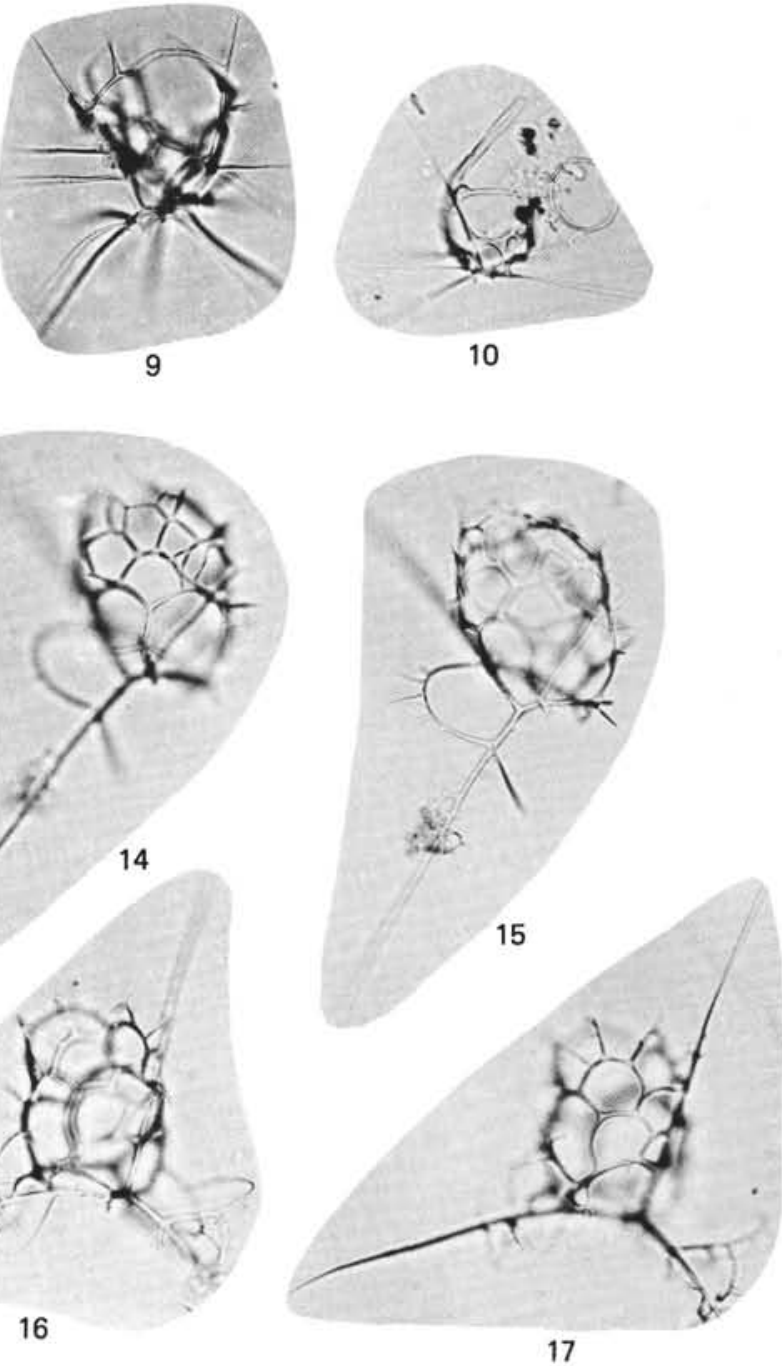
PLATE 7

Scale bar is $100 \mu \mathrm{m}$

Figures 1-4 Euscenium (?) corynephorum J $\phi$ rgensen, 1900.

1, 2. Hjeltefjorden 21/1-1899.

3, 4. Same specimen, Raftsund 3/2-1899.

Figures 5-8 Cladoscenium tricolpium (Haeckel, 1882).

5. Herdlafjorden 20/1-1899.

6. Byfjorden 21/1-1899.

7. Helligvaer $12 / 1-1899$.

8. Vesteralen 19/1-1899.

Figures 9-15 Peridium longispinum J $\phi$ rgensen, 1900.

9, 10. Senja 21/1-1899.

11, 12. Herdlafjorden 28/2-1899.

13. Malangen 29/1-1899.

14. Helligvaer 12/1-1899.

15. Vesteralen 19/1-1899.

(see page 1140)

\author{
PLATE 8 \\ Scale bar is $100 \mu \mathrm{m}$
}

Figures 1-13 Lithomelissa setosa J $\phi$ rgensen, 1900.

1-3. Herdlafjorden 20/1-1899.

4. Herdlafjorden 28/2-1899, apical view.

5. Byfjorden $21 / 2-1899$.

6-8. Malangen 29/1-1899.

9. Helligvaer 12/1-1899.

10-13. Kvaenangen 24/1-1899.

Figures 14-18 Lithomelissa hystrix J $\phi$ rgensen, 1900.

14,15 . Same specimen; all from Vesteralen 19/11899.

Figures 19-24 Ceratocyrtis histricosus (J $\phi$ rgensen, 1905).

19, 20. Same specimen.

22. Skraven 4/2-1899.

$21,23,24$. Vestfjorden 1/2-1899.

(see page 1141) 
PLATE 7
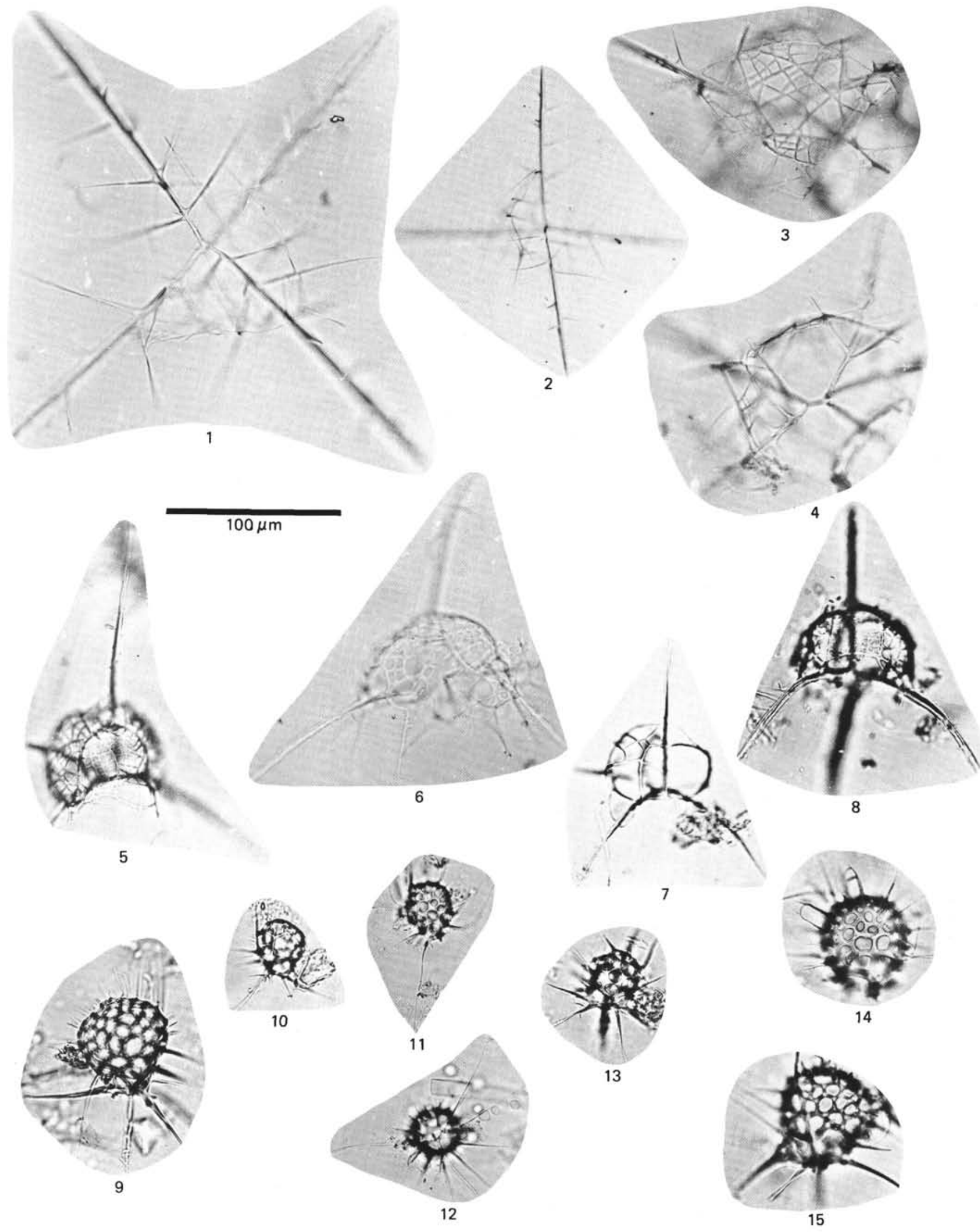
PLATE 8
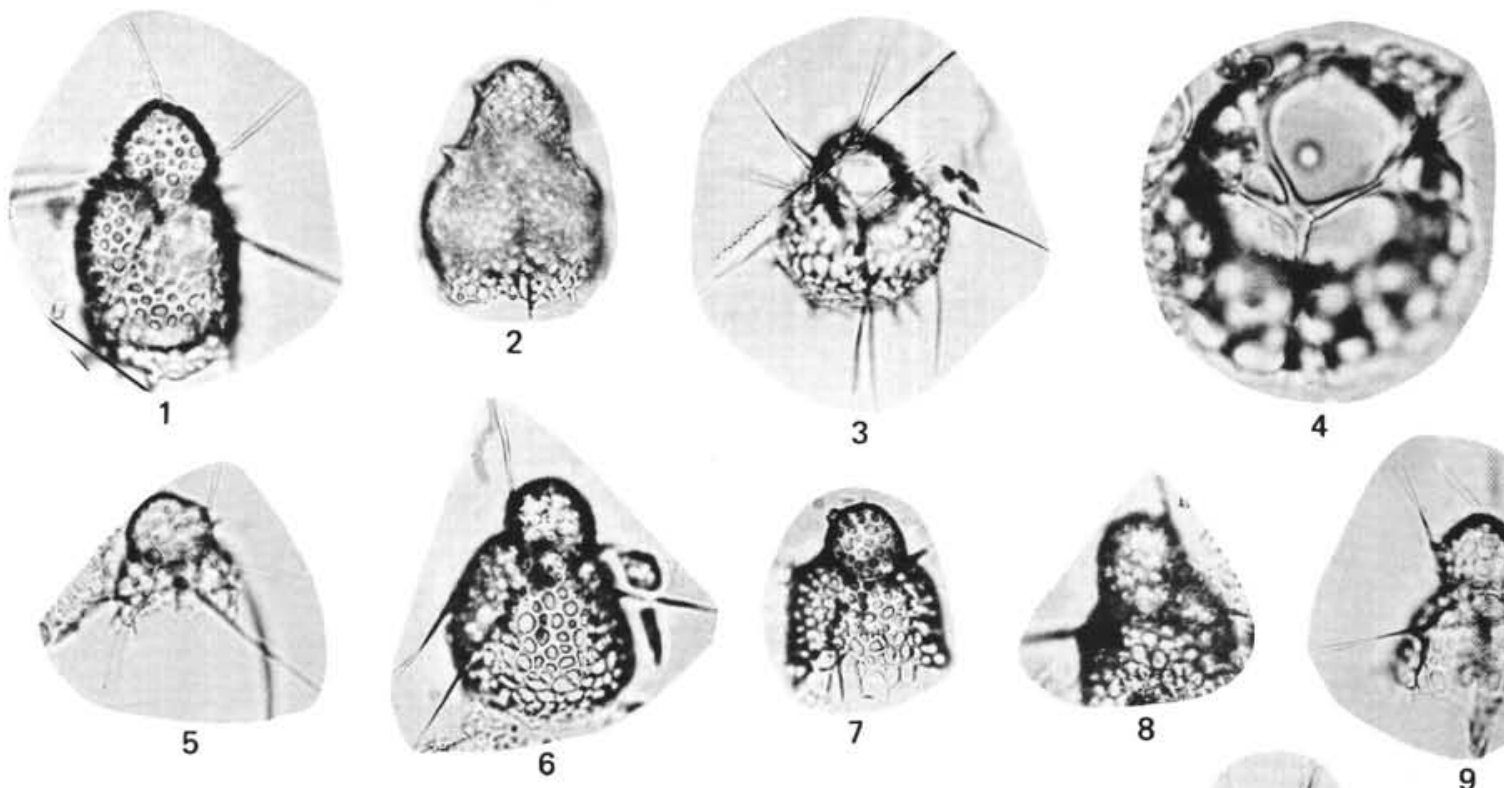

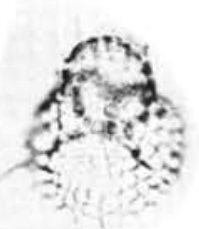

10

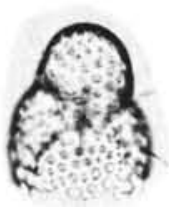

11

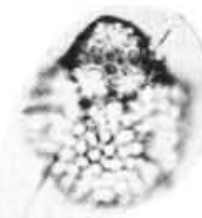

12
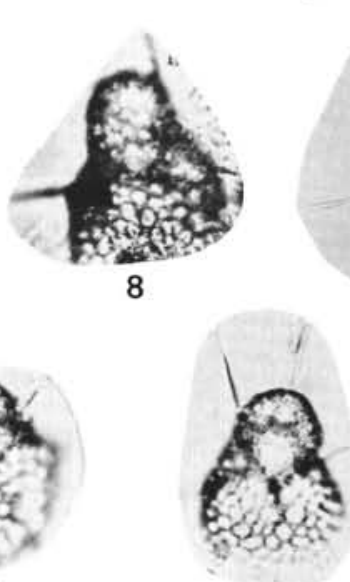

13

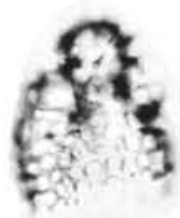

14

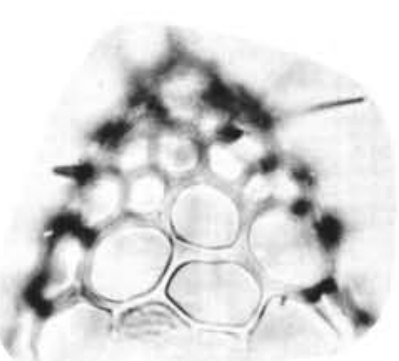

19

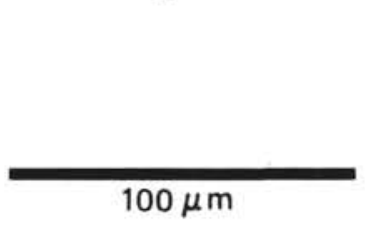

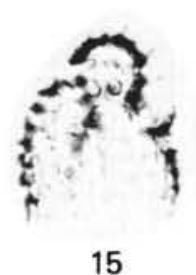

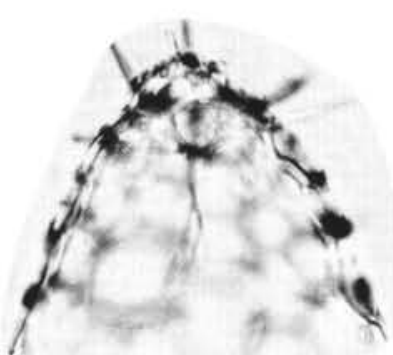

20

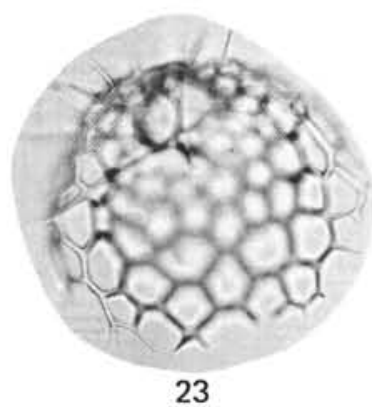

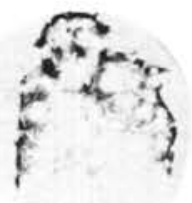

17

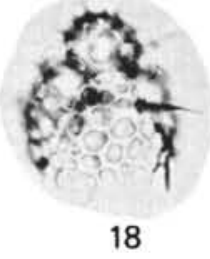

16

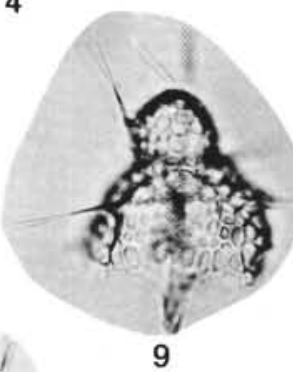

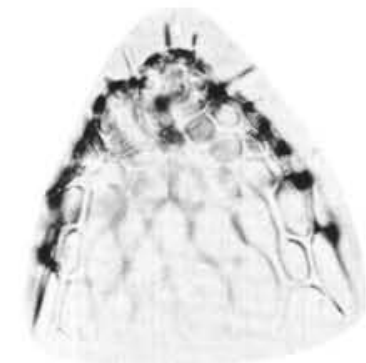

21

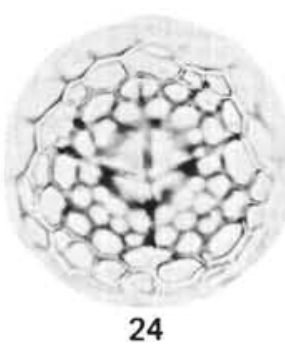

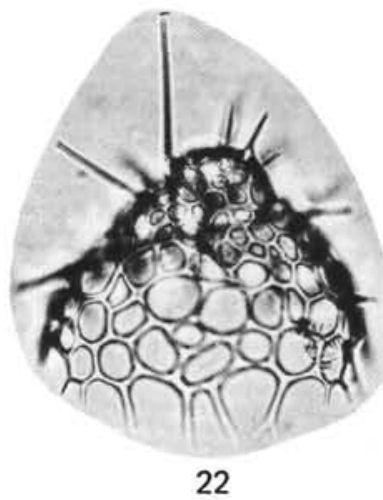




\section{PLATE 9}

Scale bar is $100 \mu \mathrm{m}$

Figures 1-5 Pseudodictyophimus gracilipes (Bailey, 1856).

1-4. Vesteralen 19/1-1899.

5. Malangen 29/1-1899.

Figure 6 Litharachnium tenthorium Haeckel, 1862. Skråven 4/4-1899.

Figures 7-10 Gonosphaera primordialis J $\phi$ rgensen, 1905. Herdlafjorden 28/2-1899.

Figures 11-15 Corocalyptra craspedota (J $\phi$ rgensen, 1900). 11-14. Vestfjorden 1/2-1899.

15. Vesteralen 19/1-1899.

\section{PLATE 10}

Scale bar is $100 \mu \mathrm{m}$

Figure 1 Dictyoceras acanthicum J $\phi$ rgensen, 1900. Kvaenangen 24/1-1899.

Figures 2-6 Androcyclas gamphonycha (J $\phi$ rgensen, 1900).

2. Vestfjorden 13/1-1899.

3. Skraven $4 / 2-1899$.

4, 5. Herdlafjorden 21/6-1899.

6. Vestfjorden 1/2-1899.

Figures 7-12 Stichocorys seriata (Jörgensen, 1905).

7, 8. Vesteralen 19/1-1899.

9, 10. Kvaenangen 24/1-1899.

11, 12. Kvaenangen 6/2-1899.

Figures 13,14 Ceratospyris hyperborea J $\phi$ rgensen, 1905.

Vestfjorden 1/2-1899. 


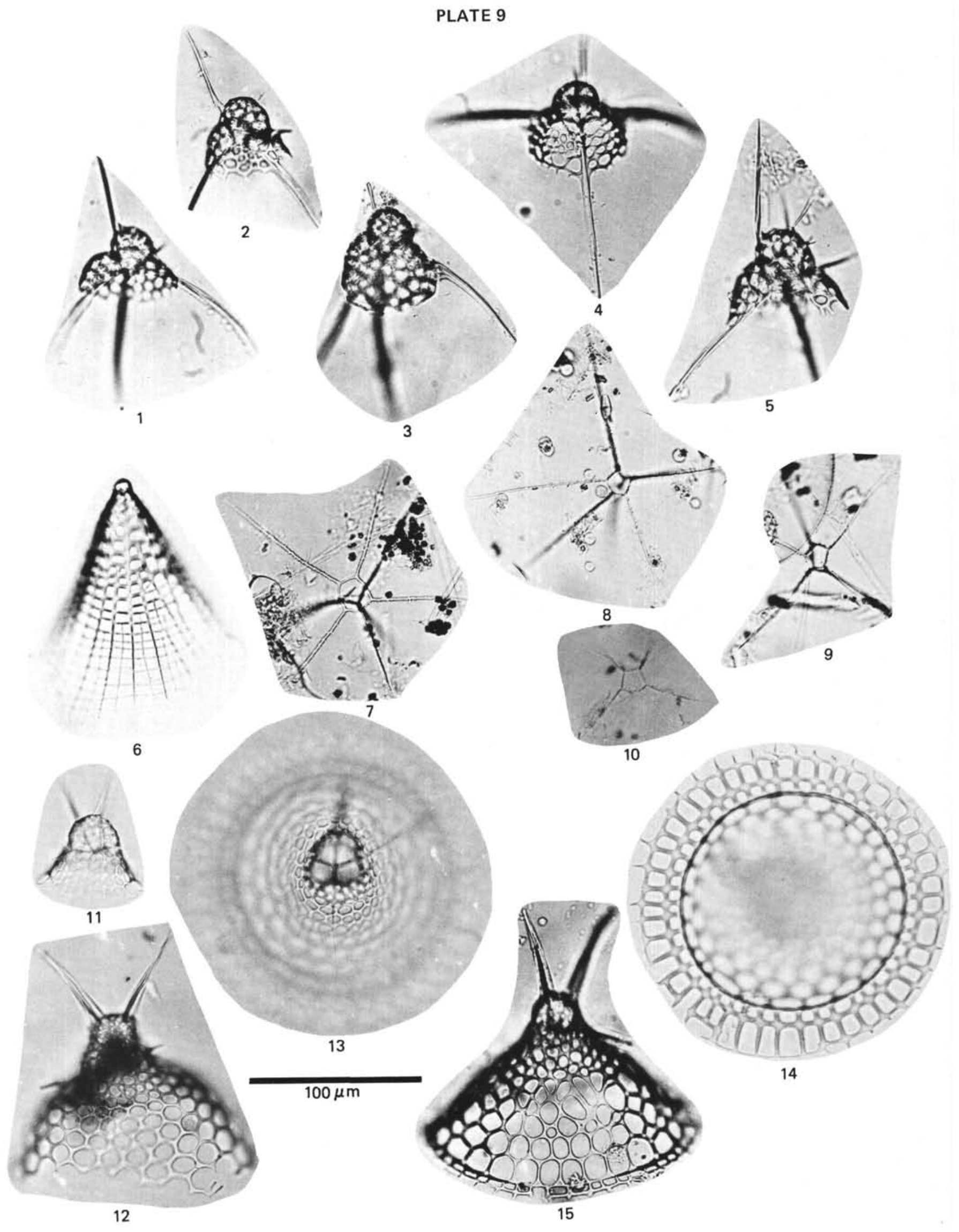

Plate 9 
K. R. BJ $\phi$ RKLUND

PLATE 10
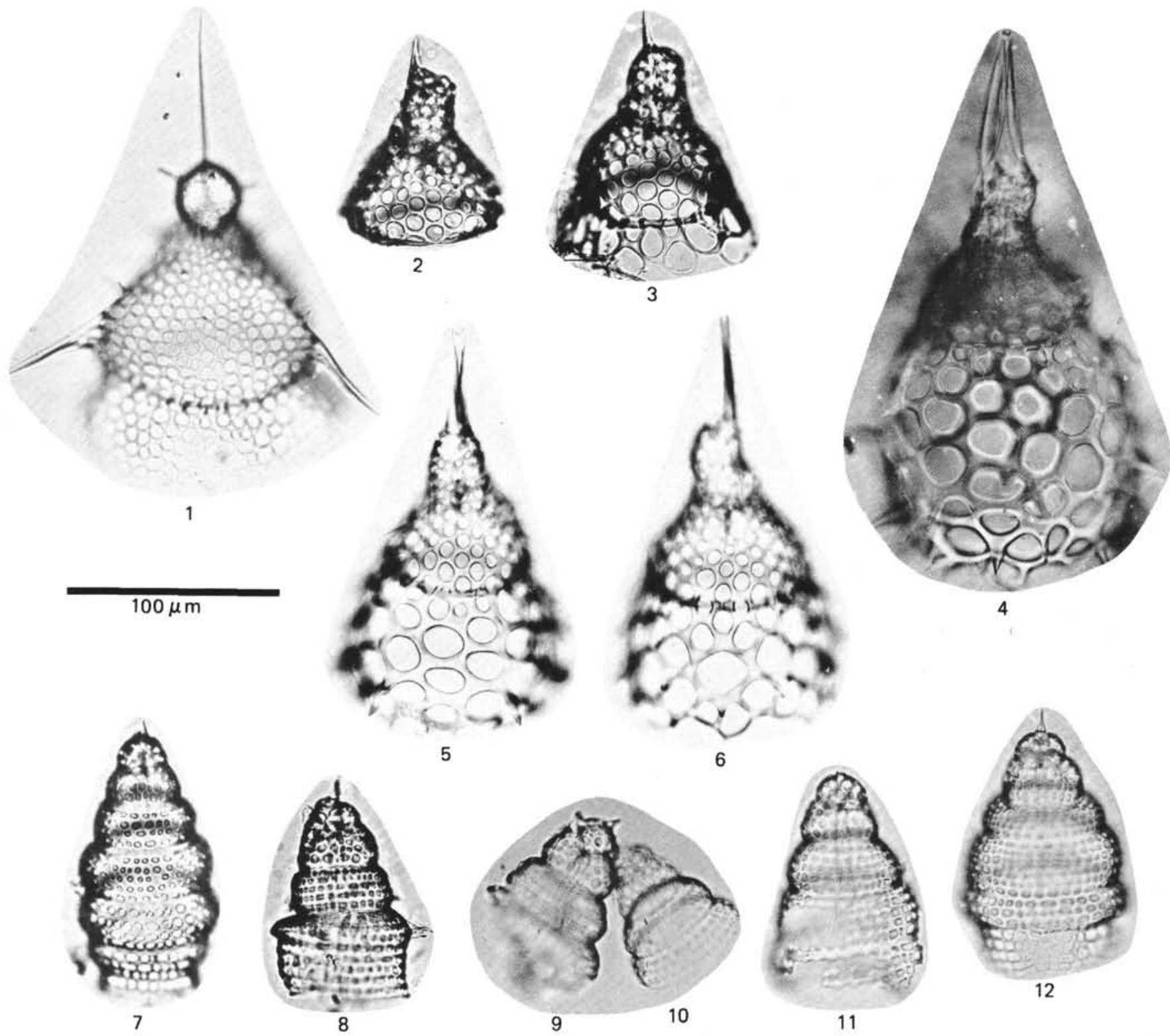

5
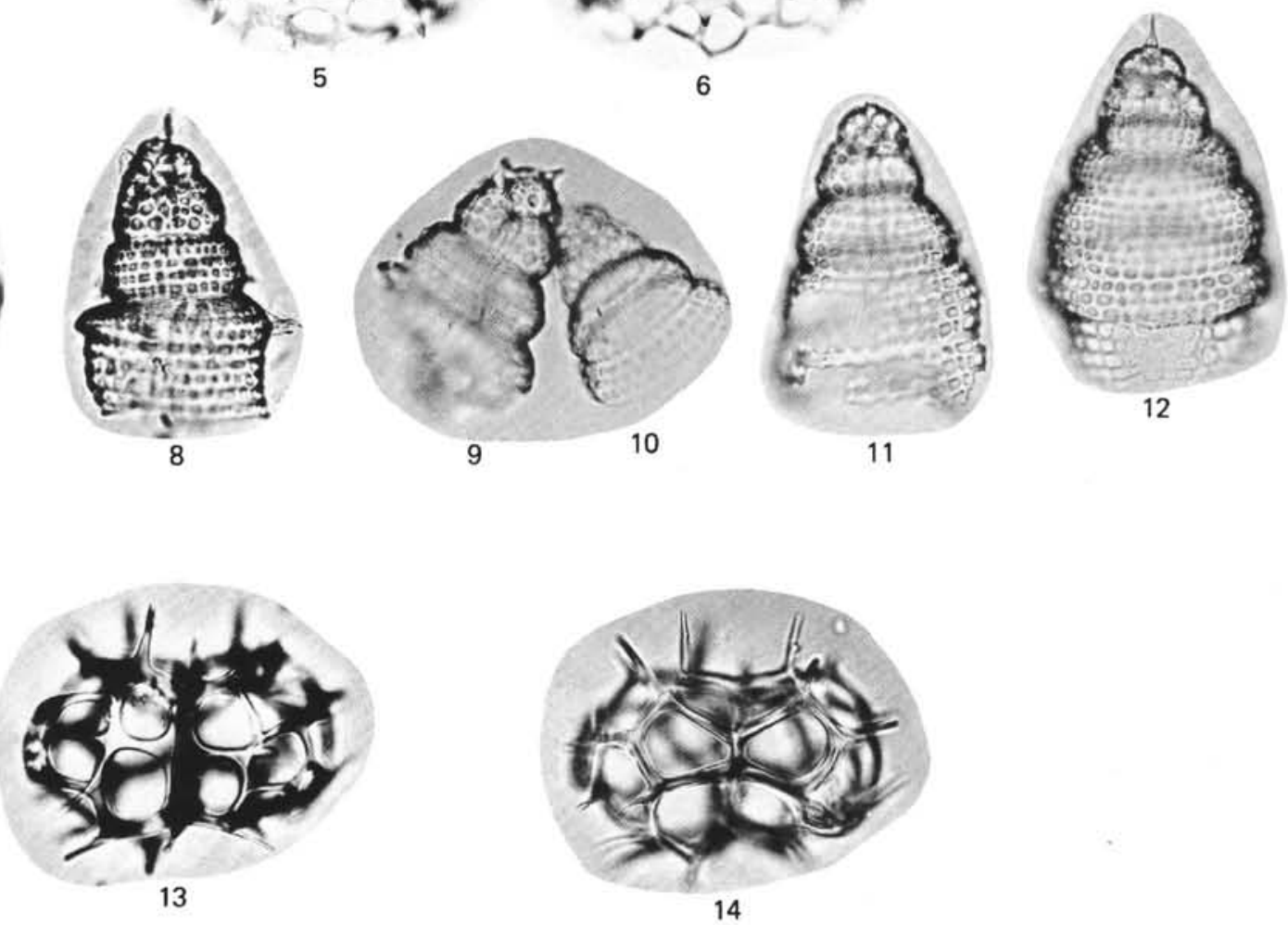


\section{PLATE 11}

Scale bar is $100 \mu \mathrm{m}$

Figures 1-3 Ceratocyrtis galeus (Cleve, 1899). 349-1-1, 10-12 cm.

Figures 4, 5 Ceratocyrtis histricsus (J $\phi$ rgensen, 1905). $349-1-1,10-12 \mathrm{~cm}$.

Figures 6,7 Pseudodictyophimus gracilipes (Bailey, 1856). 349-1-1, 10-12 cm.

Figure $8 \quad$ Spongotrochus glacialis Popofsky, 1908. 349-1-1, 10-12 cm.

Figures 9, 10 Cycladophora davisiana Ehrenberg, 1862.

Figure 11 Dictyoceras acanthicum J $\phi$ rgensen, 1900. 349-1-1, 10-12 cm.

Figures 12,13 Artostrobus joergenseni Petrushevskaya, 1971. 349-1-1, 10-12 cm.

Figure $14 \quad$ Artostrobus annulatus (Bailey, 1856). 349-1-1, 10-12 cm.

Figure $15 \quad$ Cornutella profunda Ehrenberg, 1854. $349-1-1,10-12 \mathrm{~cm}$.

Figure $16 \quad$ Lithomitra lineata Ehrenberg, 1838. 349-1-1, 10-12 cm.

Figures 17, 18 Lithomitra platycephala (?) (Ehrenberg, 1872). $349-1-1,10-12 \mathrm{~cm}$.

Figures 19-23 Lithomelissa setosa J $\phi$ rgensen, 1900. 349-1-1, 10-12 cm.

Figures 24-27 Artobotrys borealis (Cleve, 1899). 349-1-1, 10-12 cm.

Figures 28-32 Amphimelissa setosa (Cleve, 1899). $349-1-1,10-12 \mathrm{~cm}$. 

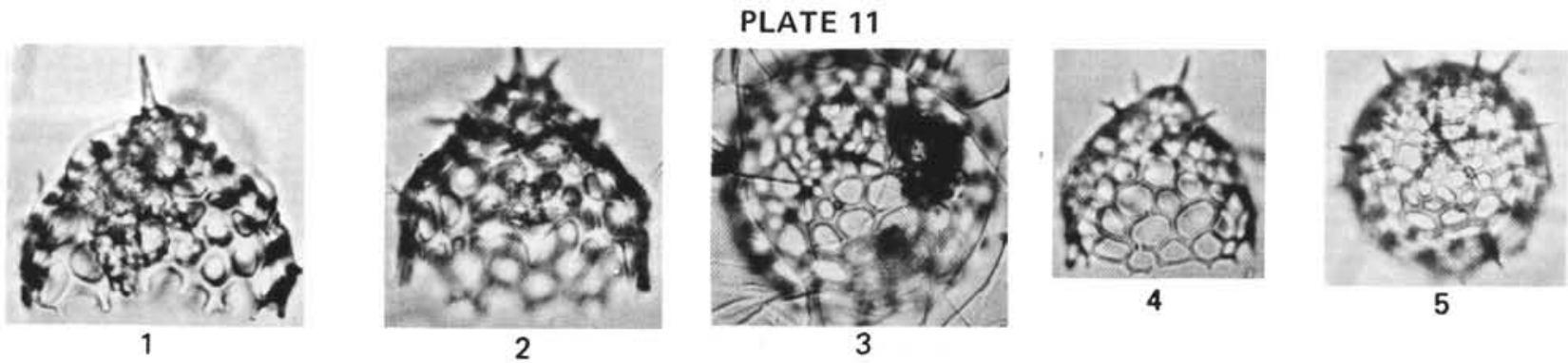

5
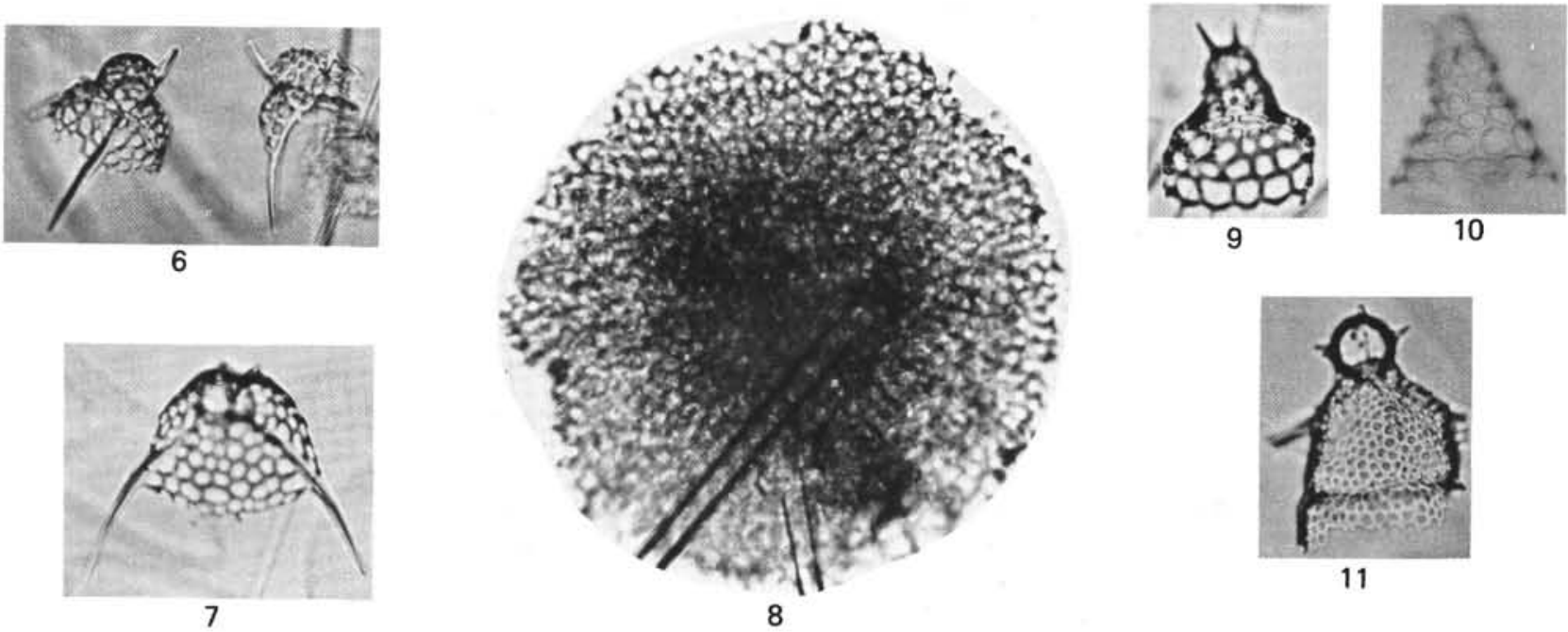

8
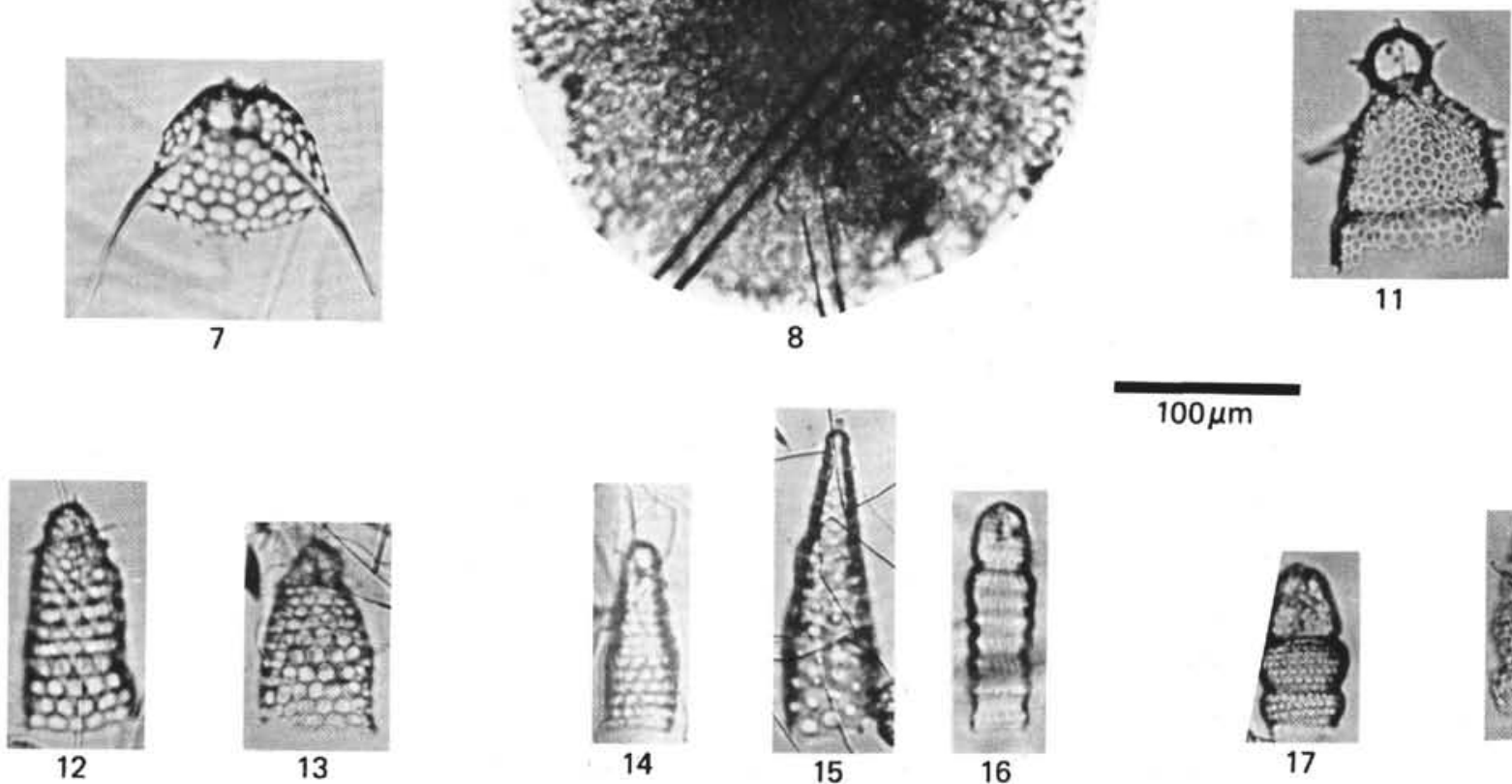

$100 \mu \mathrm{m}$
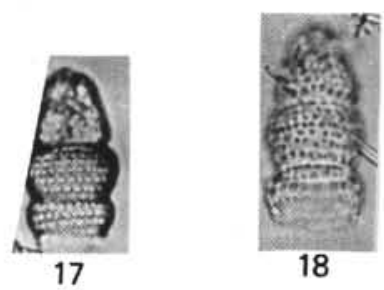

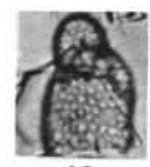

19
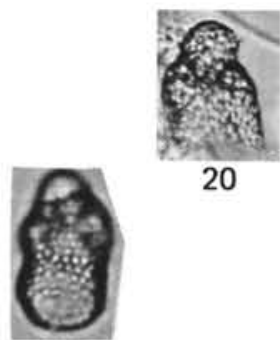

21
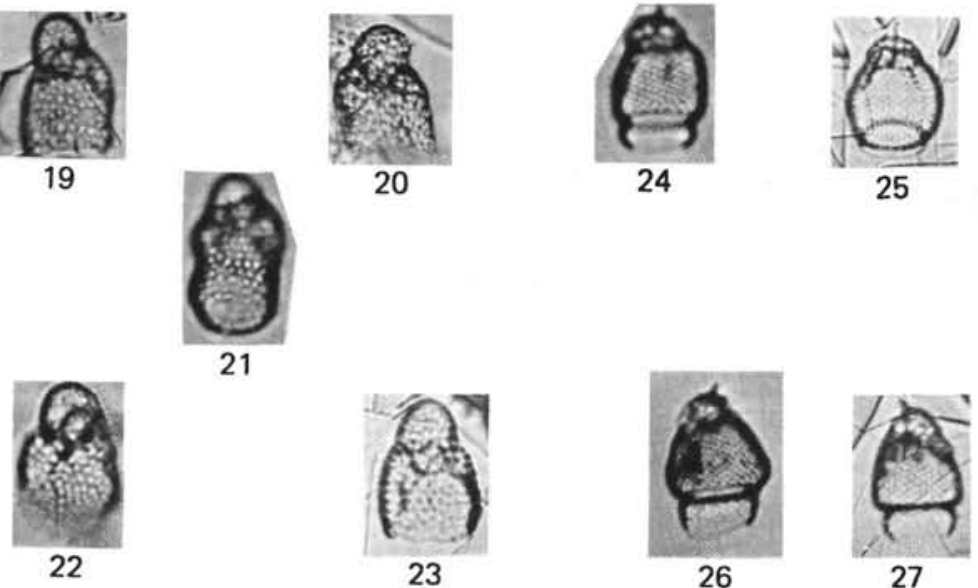

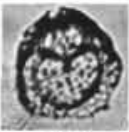

28
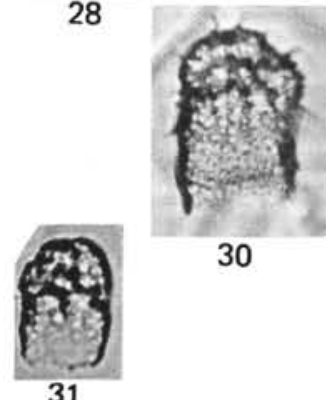

30

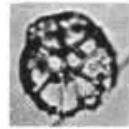

29 


\section{PLATE 12}

Scale bar is $100 \mu \mathrm{m}$ except Figure 13 is $30 \mu \mathrm{m}$

Figures 1-3 Protocystis tridens (Haeckel, 1887).

1. North Atlantic, no date, Cleve collection.

2,3 . Herdlafjorden, $20 / 1$ and $14 / 31899$, respectively. J $\phi$ rgensen collection.

Figure $4 \quad$ Protocystis xiphodon (Haeckel, 1887).

Vesteralen 19/1 1899, J $\phi$ rgensen collection.

Figures 5-7 Protocystis harstoni (Murray, 1885).

5. Herdlafjorden, 14/3 1899, J $\phi$ rgensen collection.

6, 7. North Atlantic, no date, Cleve collection.

Figures 8-11 Challengeron diodon Haeckel, 1887.

8 , 9. Herdlafjorden, 28/2 1899, J $\phi$ rgensen collection.

10, 11. North Atlantic, no date, Cleve collection.

Figures 12,13 Porospathis holostoma (Cleve, 1899).

North Atlantic, no date, Cleve collection.

Figure $14 \quad$ Cadium melo (Cleve, 1899).

North Atlantic, no date, Cleve collection.

Figure $15 \quad$ Cadium bullatum (?) Stadum and Ling, 1969.

North Atlantic, no date, Cleve collection.

(see page 1148)

PLATE 13

Scale bar is $50 \mu \mathrm{m}$

Figures 1-8 Antarctissa (?) sp.

348-4-2, 106-108 cm.

Figures 9-14 Antarctissa whitei n. sp.

348-6-3, 50-52 cm.

Figures 15-21 Challengeron (?) spp.

348-6, CC.

(see page 1149) 


\section{PLATE 12}
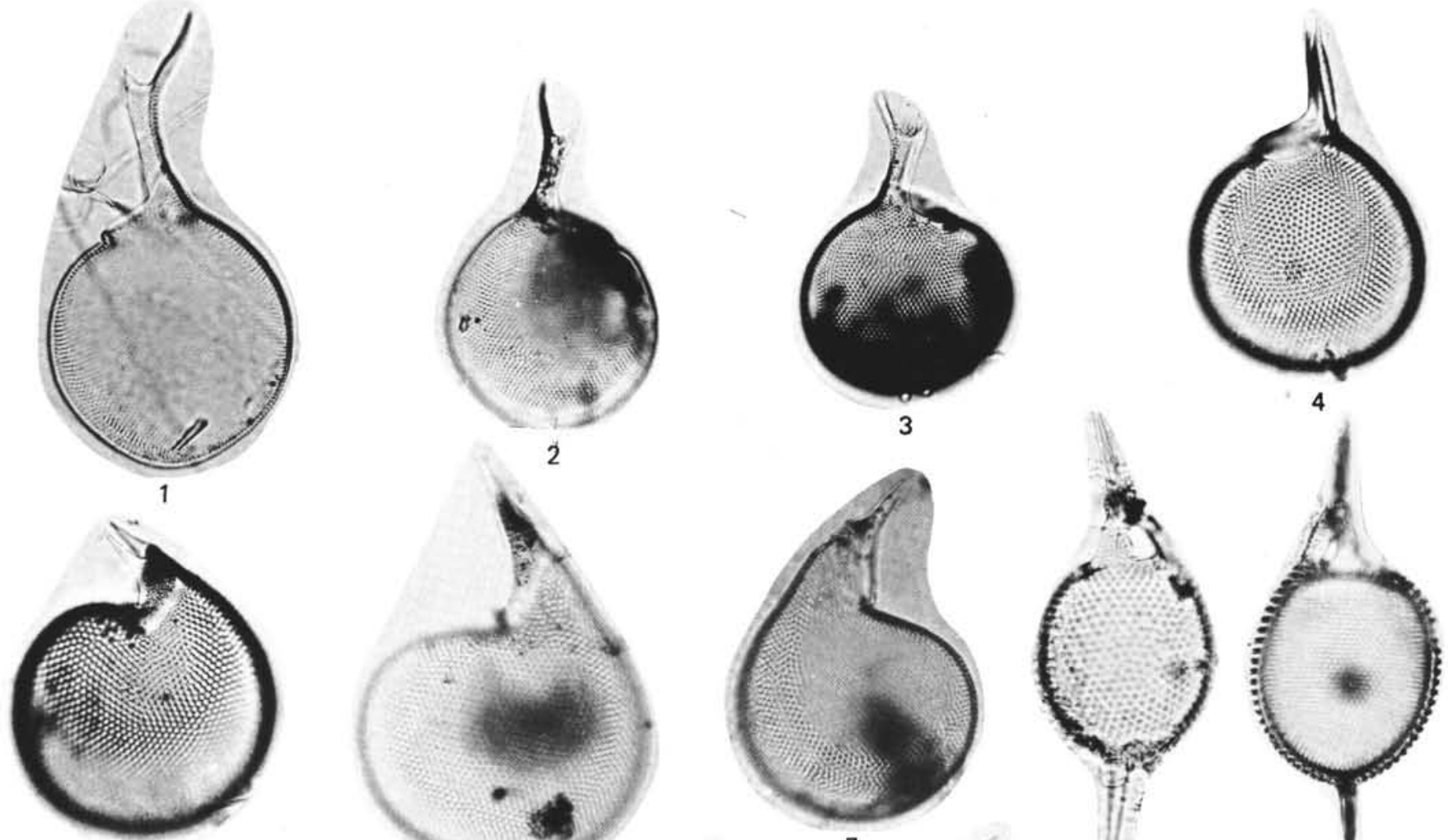

5
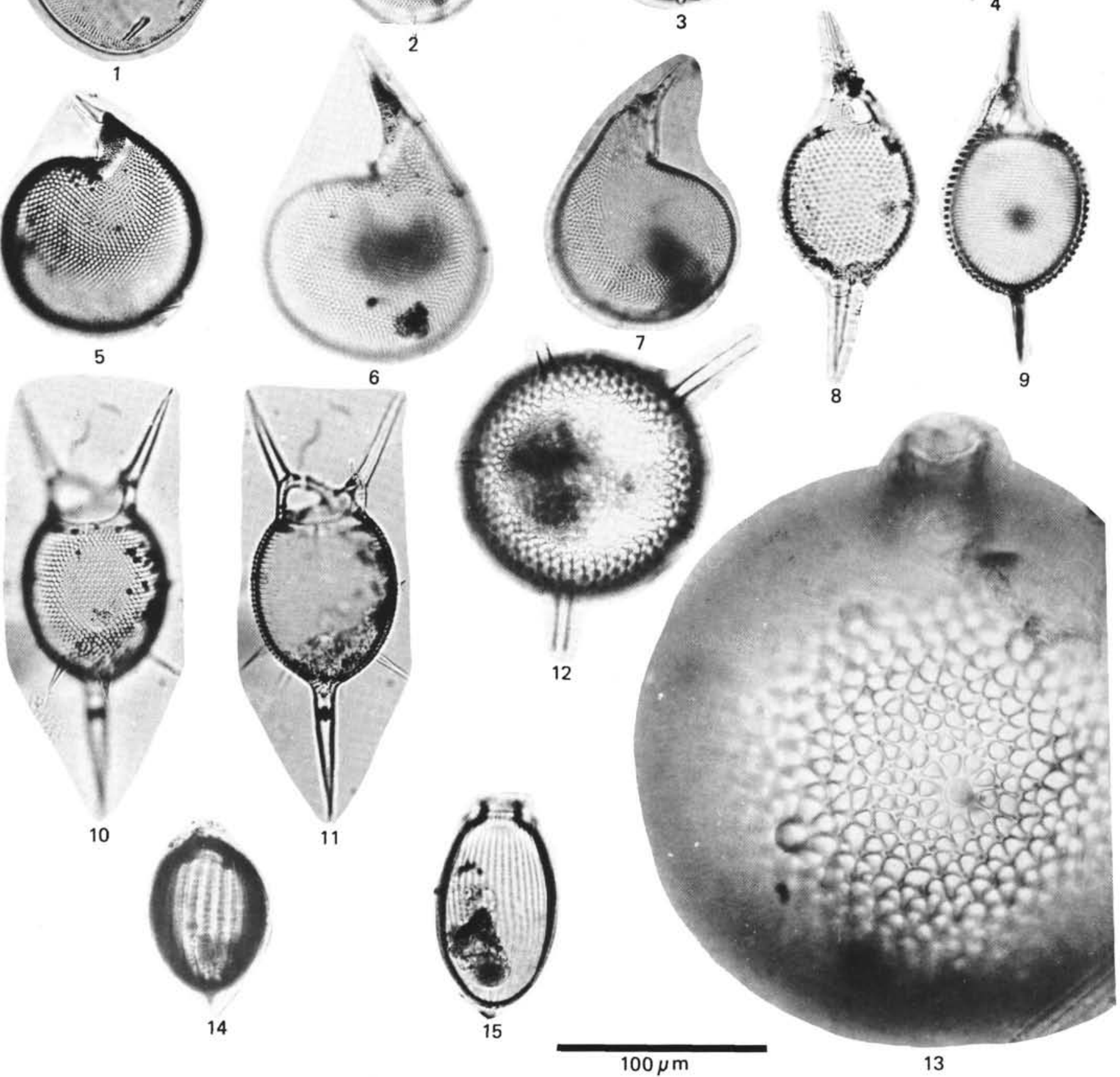
PLATE 13
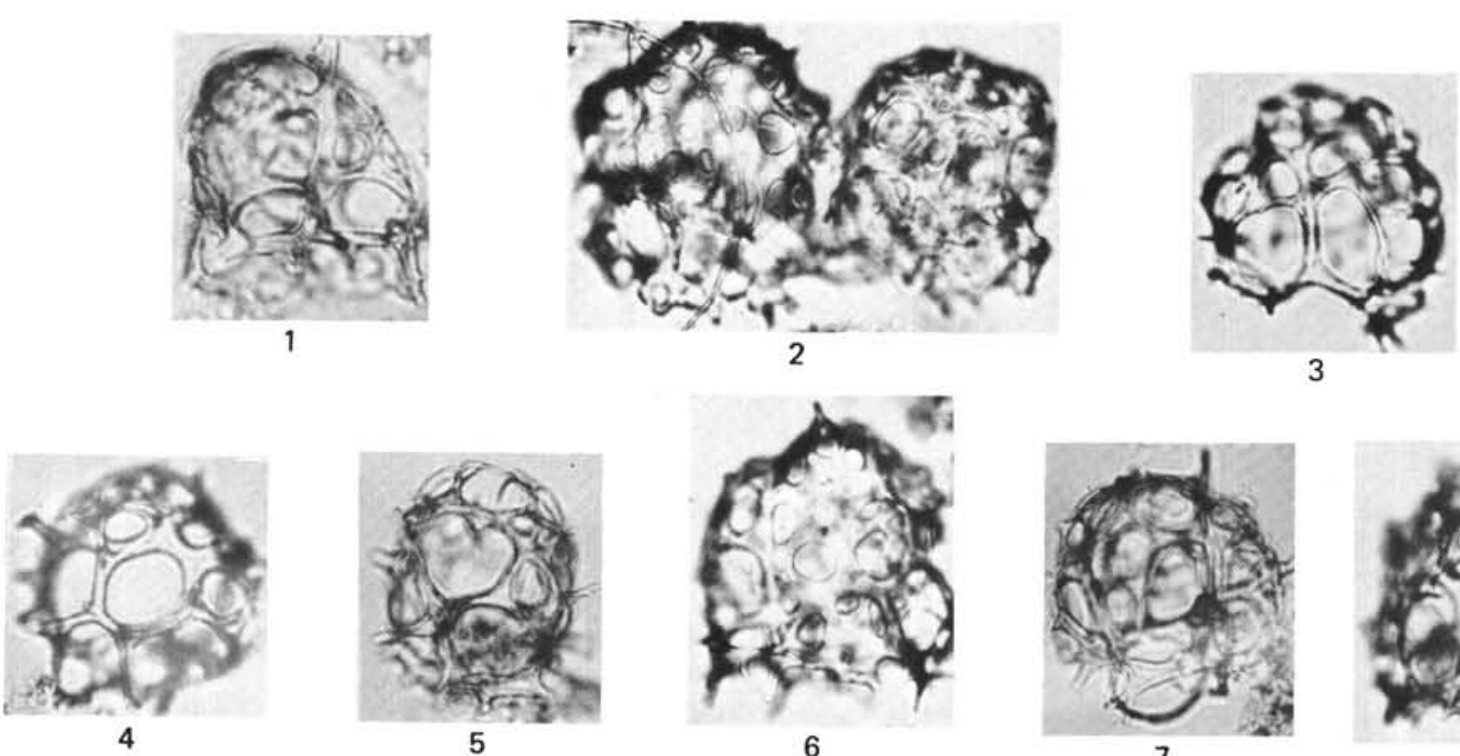

6
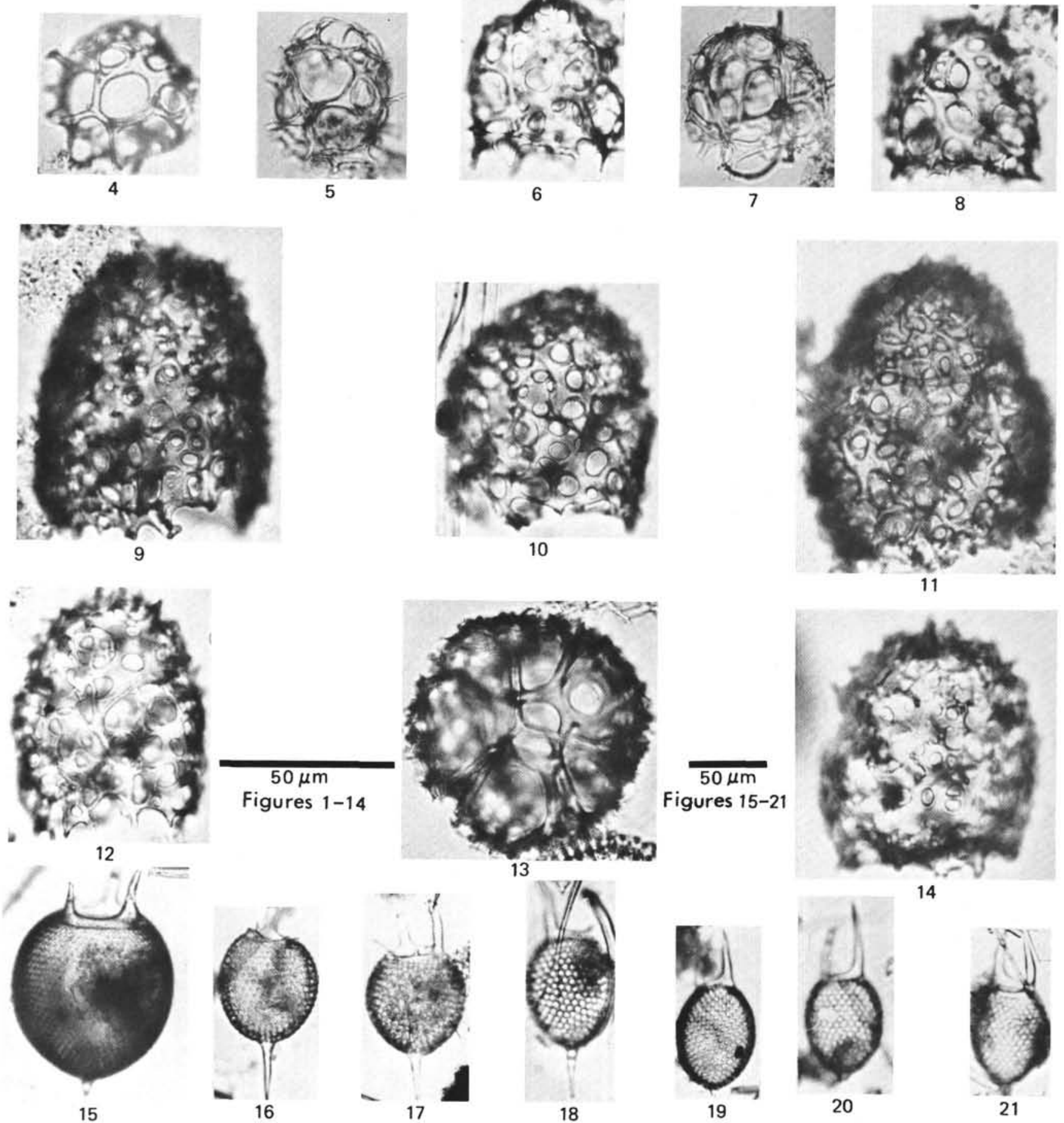

Figures 15-21
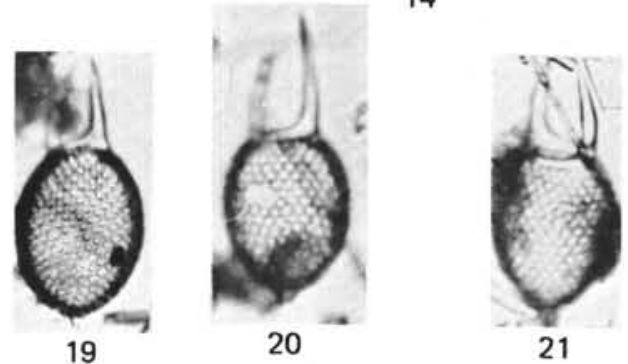
PLATE 14

Scale bar is $100 \mu \mathrm{m}$

Figures 1-6 Hexalonche sp. A.

1-3. $338-8-2,53-55 \mathrm{~cm}$.

4, 5. $338-8-3,45-47 \mathrm{~cm}$.

6. $338-11-3,135-137 \mathrm{~cm}$.

Figures 7-9 Hexalonche sp. B.

7. $338-11-3,135-137 \mathrm{~cm}$.

8. $338-11-1,145-147 \mathrm{~cm}$.

9. $338-11, \mathrm{CC}$.

Figures 10-12 Heteracantha dentata Mast, 1910.

10. 338-10-1, 115-117 cm.

11,12 . $338-12-2,145-147 \mathrm{~cm}$.

Figures 13,14 Heliodiscus sp.

338-11-3, 135-137 cm.

Figures 15, 16 Stylosphaera sp. $338-11-3,135-137 \mathrm{~cm}$.

Figure $17 \quad$ Pylosphaera (?) sp. 338-13-3, 145-147 cm.

Figure 18 Spongotrochus glacialis Popofsky, 1908. 338-10-1, 115-117 cm. 
PLATE 14
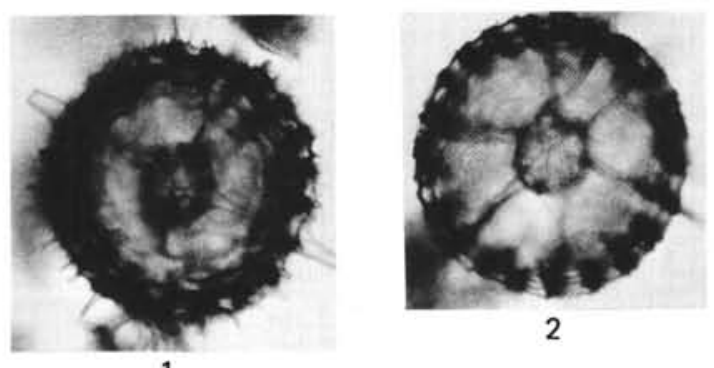

2

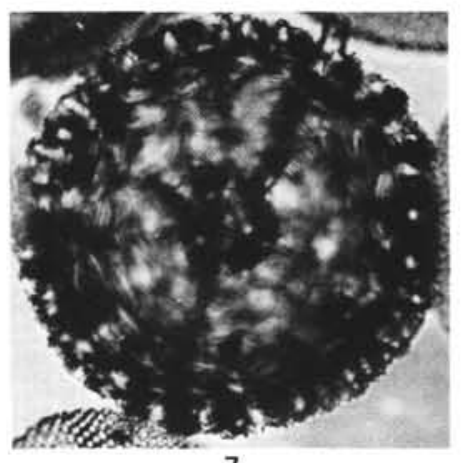

7

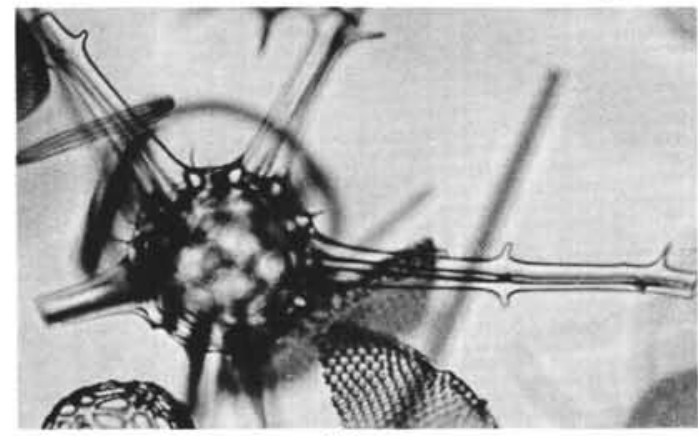

10
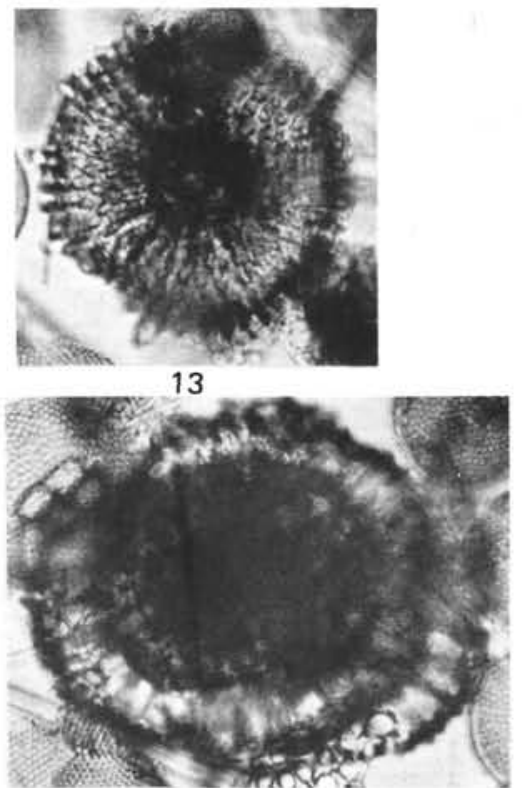

17
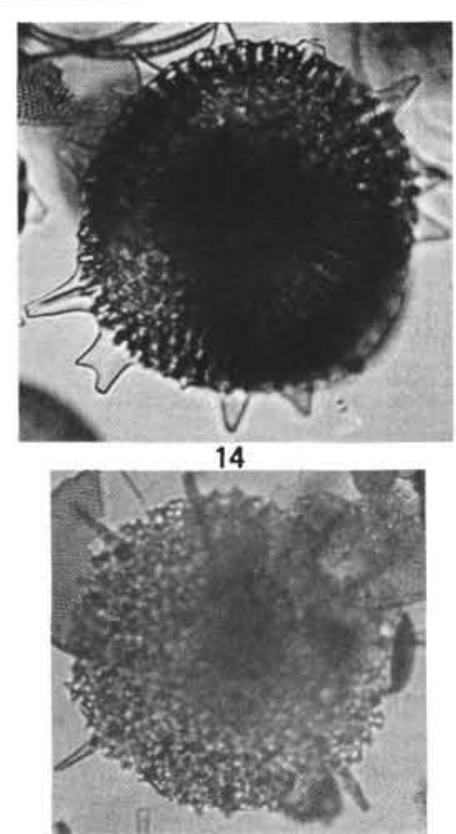

18
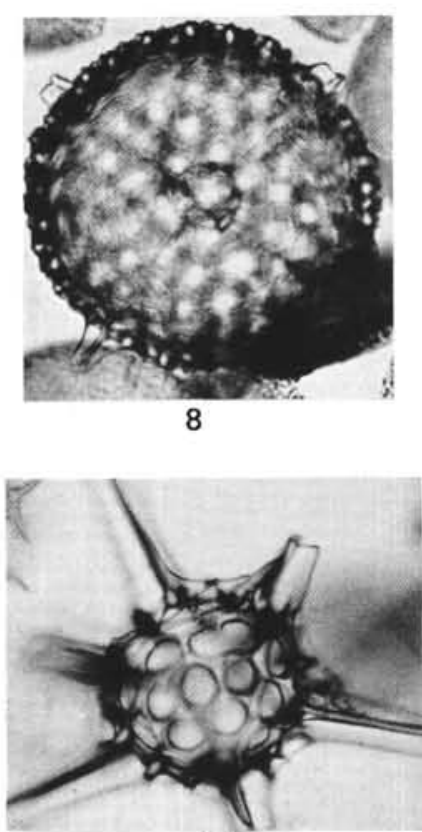

11

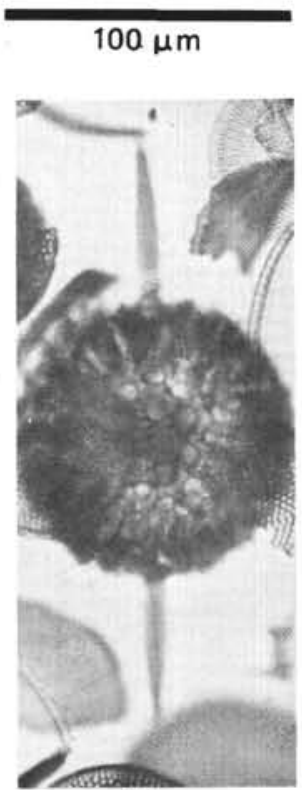

15
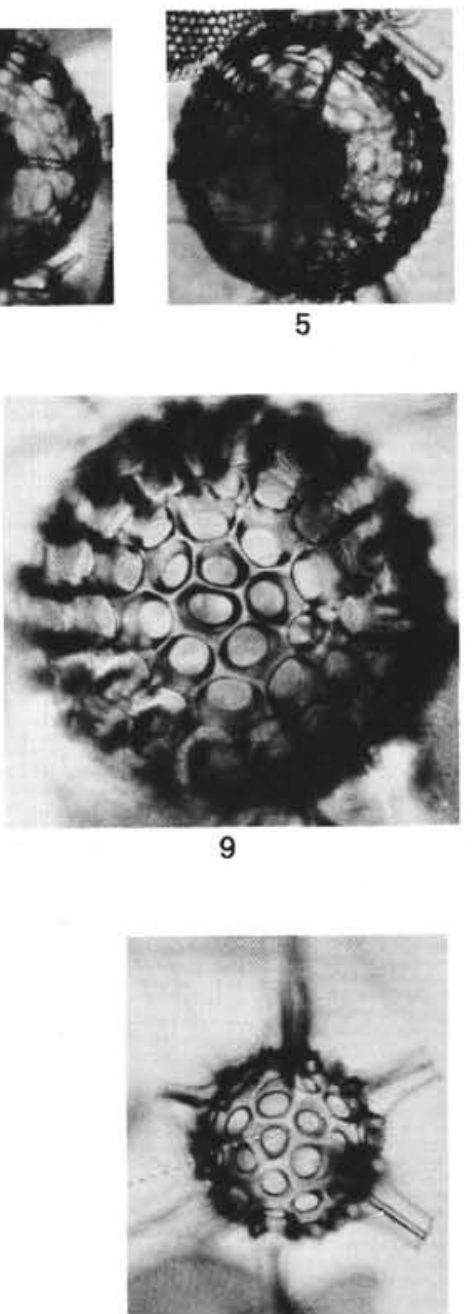

12

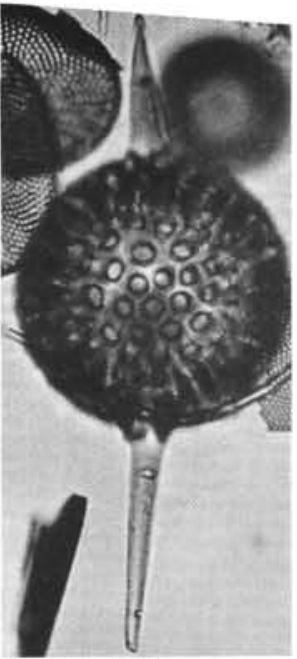

16 
PLATE 15

Scale bar is $100 \mu \mathrm{m}$

Figures 1-3 Ceratocyrtis $\mathrm{sp}$.

1. $341-28-3,79-81 \mathrm{~cm}$.

2, 3. $341-29-2,100-102 \mathrm{~cm}$.

Figure 4 Antarctissa whitei n. sp. 341-25, CC.

Figure $5 \quad$ Lychnocanium grande Clark and Campbell, 1942. 341-25, CC.

Figures 6-8 Ceratocyrtis sp. aff. C. histricosus (J $\phi$ rgensen, 1905).

$338-8-2,53-55 \mathrm{~cm}$.

Figures 9-11 Lithomelissa sp.

$338-8-2,53-55 \mathrm{~cm}$.

Figures 12-17 Lithomelissa stigi $\mathrm{n}$. sp.

$338-8-2,120-122 \mathrm{~cm}$; 338-8-3, 45-47 cm.

Figures 18-22 Tricerospyris sp.

18. $338-8-3,45-47 \mathrm{~cm}$.

19. $338-8$, CC.

20, 21. 338-9-1, 85-87 cm.

22. $338-10-1,115-117 \mathrm{~cm}$.

Figure 23 Cornutella $\mathrm{sp}$.

$338-8-3,45-47 \mathrm{~cm}$.

Figure 24 Corocalyptra sp. aff. C. craspedota (J $\phi$ rgensen, 1900).

$338-9-1,85-87 \mathrm{~cm}$.

Figure $25 \quad$ Nassellaria. Gen. et sp. indet.

$338-9-1,85-87 \mathrm{~cm}$.

Figures 26-28 Lithomitra sp.

26, 27. 338-9-1, 85-87 cm.

28. $338-10, \mathrm{CC}$. 
PLATE 15
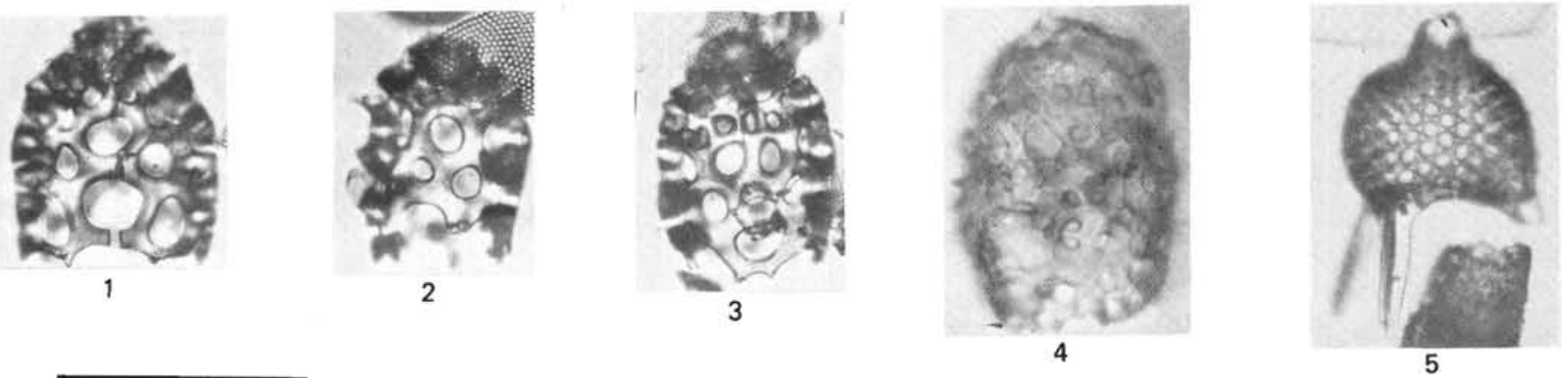

\section{$100 \mu \mathrm{m}$}

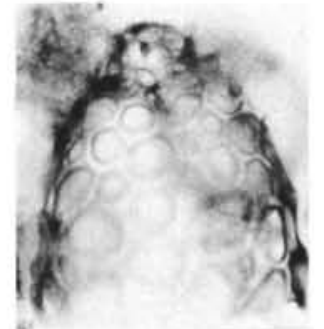

6

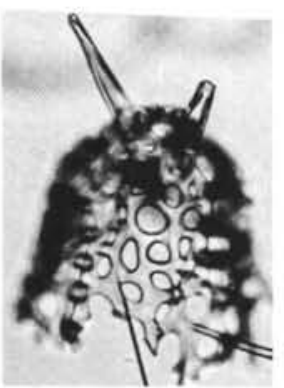

12

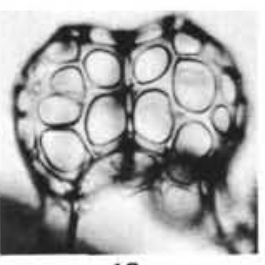

18

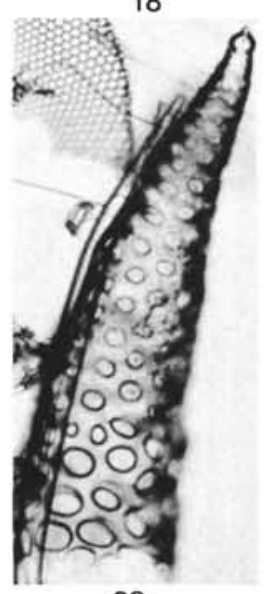

23
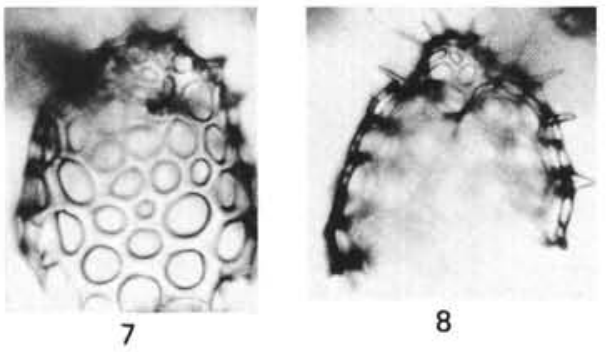

8
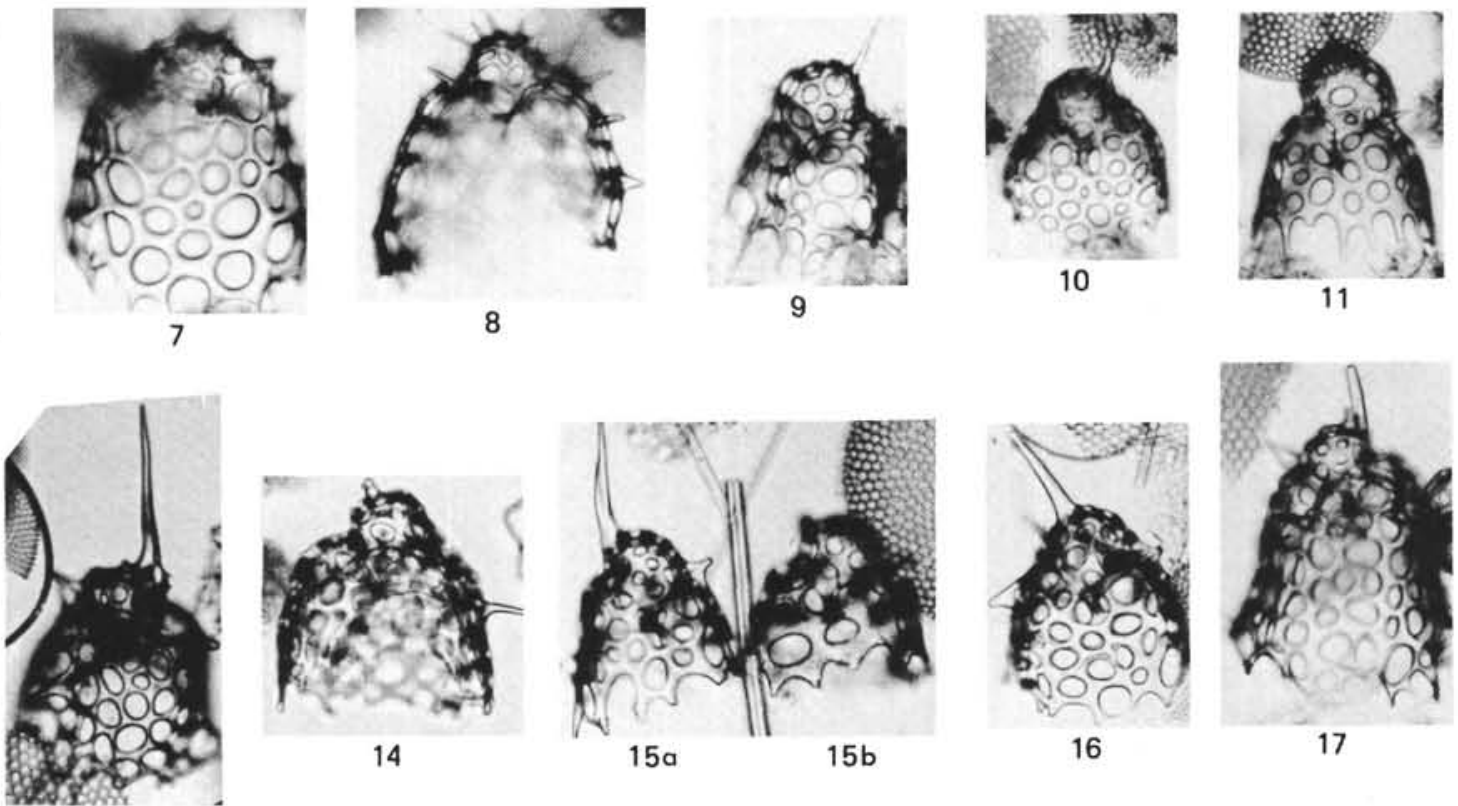

13

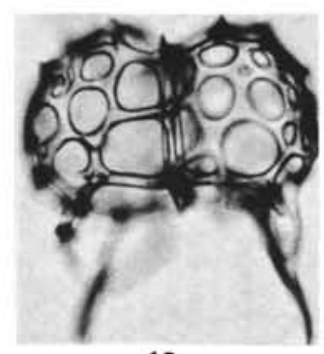

19
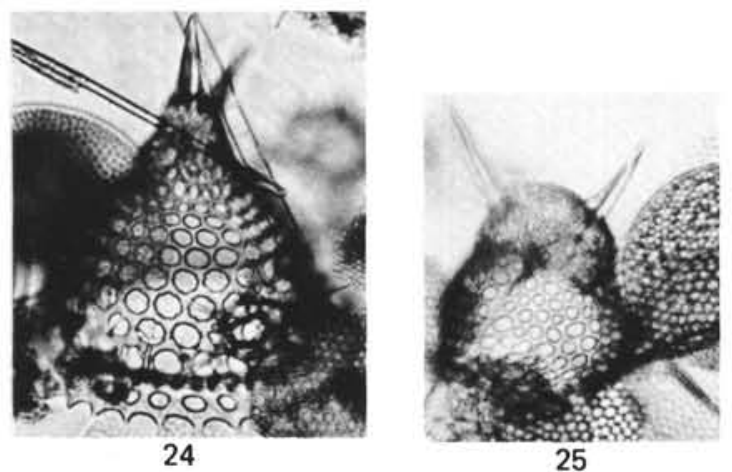
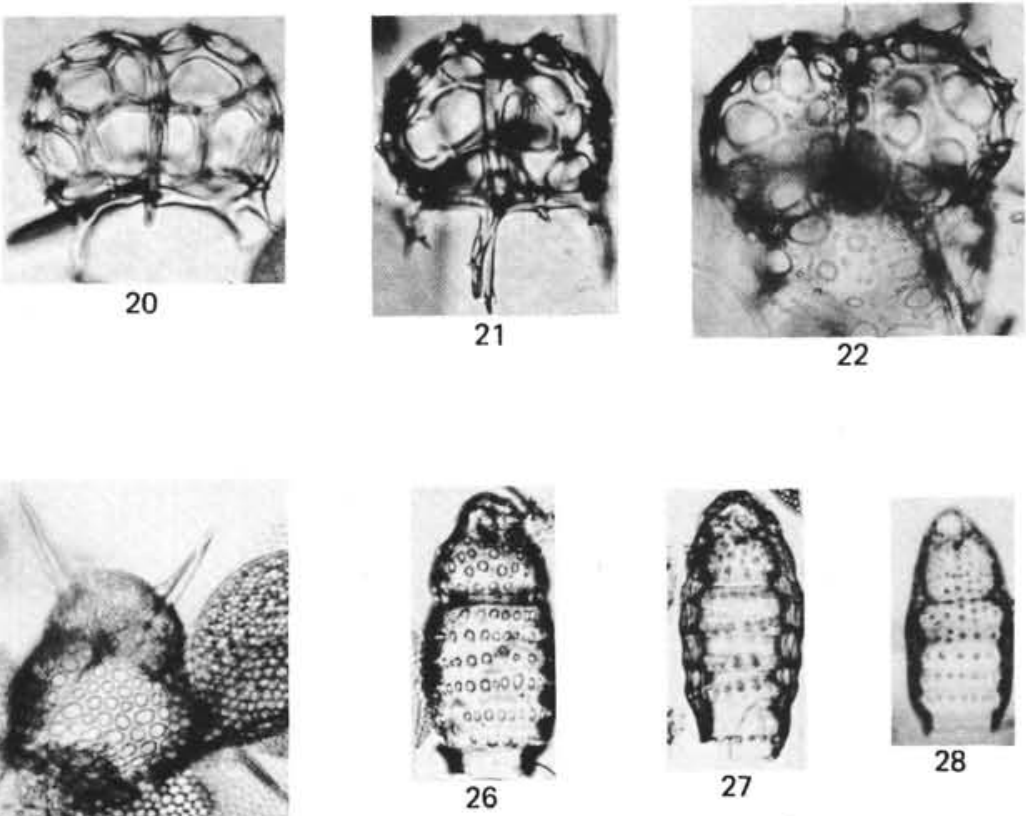


\section{PLATE 16}

Scale bar is $100 \mu \mathrm{m}$

Figures 1-5 Pseudodictyophimus sp. aff. P. gracilipes (Bailey, 1856).

1. $338-9-1,85-87 \mathrm{~cm}$.

2. $338-9, \mathrm{CC}$.

3, 4. 338-10-1, $115-117 \mathrm{~cm}$.

5. $338-11, \mathrm{CC}$.

Figures 6-8 Botryostrobus sp.

6. 338-9, CC.

7, 8. 338-10, CC.

Figures 9, 10 Botryostrobus sp.

9. $338-13-3,145-147 \mathrm{~cm}$.

10. $338-10, \mathrm{CC}$.

Figures 11-13 Lipmanella xiphephorum sensu Petrushevskaya and Kozlova, 1972.

11, 12. $338-11-3,135-137 \mathrm{~cm}$.

13. $338-12-2,145-147 \mathrm{~cm}$.

Figures 14-16 Lithomelissa (?) sp.

14, 15. 338-10-2, $146-148 \mathrm{~cm}$.

16. $338-11-1,145-147 \mathrm{~cm}$.

Figures 17-21 Stichocorys biconica Vinassa de Regny, 1900. $338-11-3,135-137 \mathrm{~cm}$.

Figures 22, 23 Tricolocapsa papillosa (Ehrenberg, 1872).

22. $338-11-1,145-147 \mathrm{~cm}$.

23. $338-11-3,135-137 \mathrm{~cm}$. 
PLATE 16
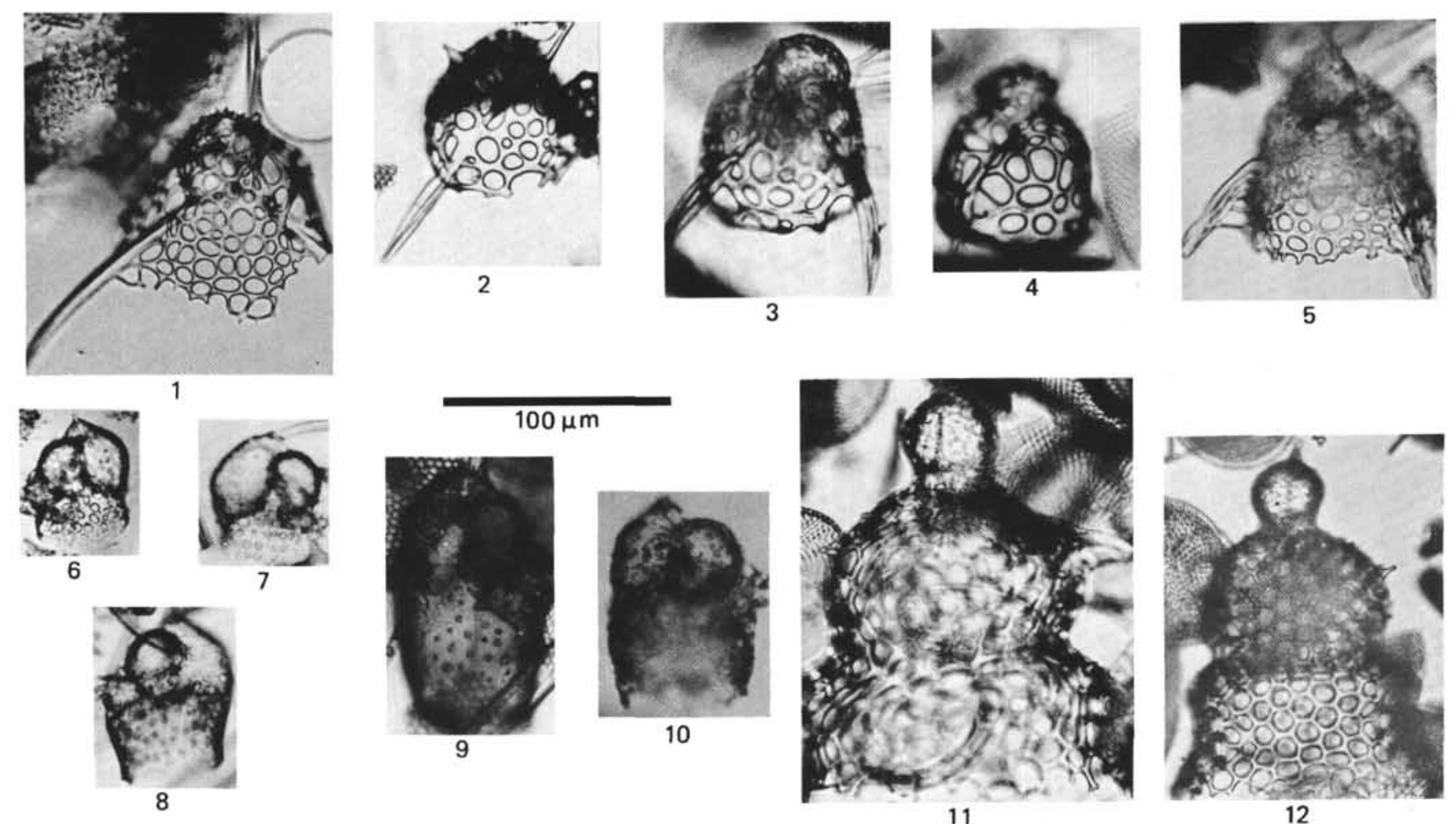
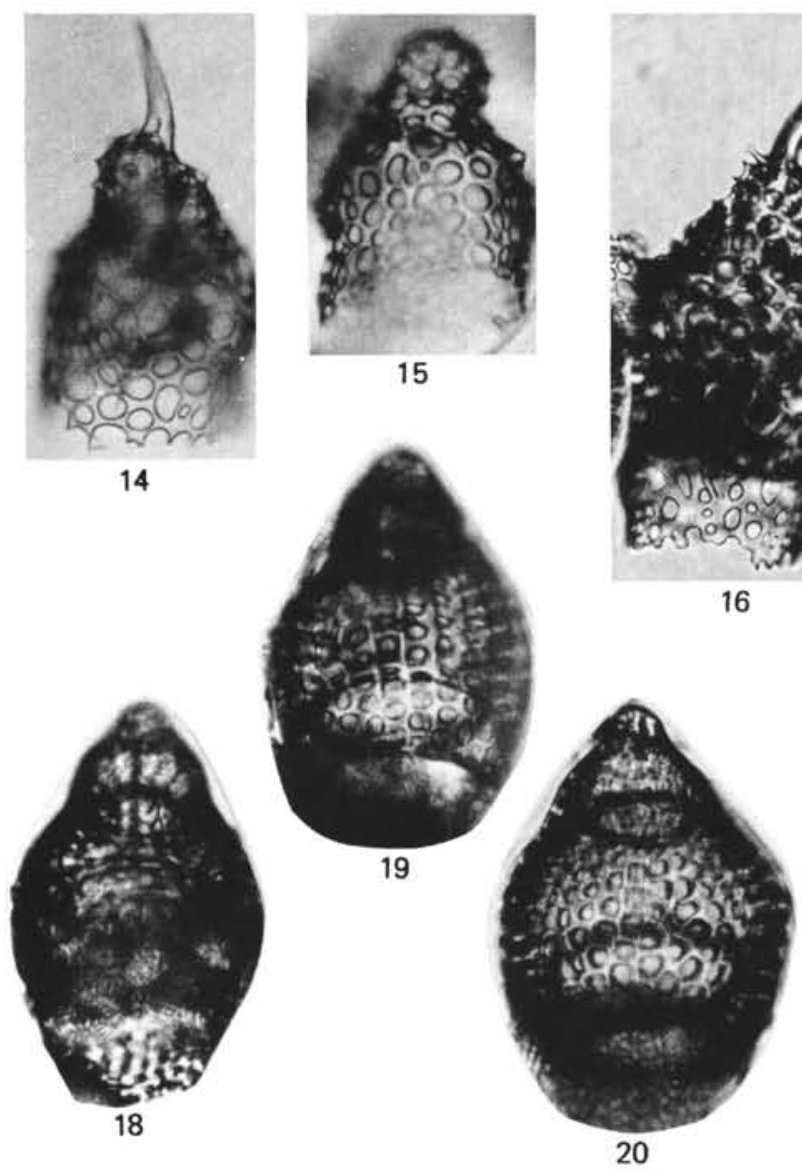
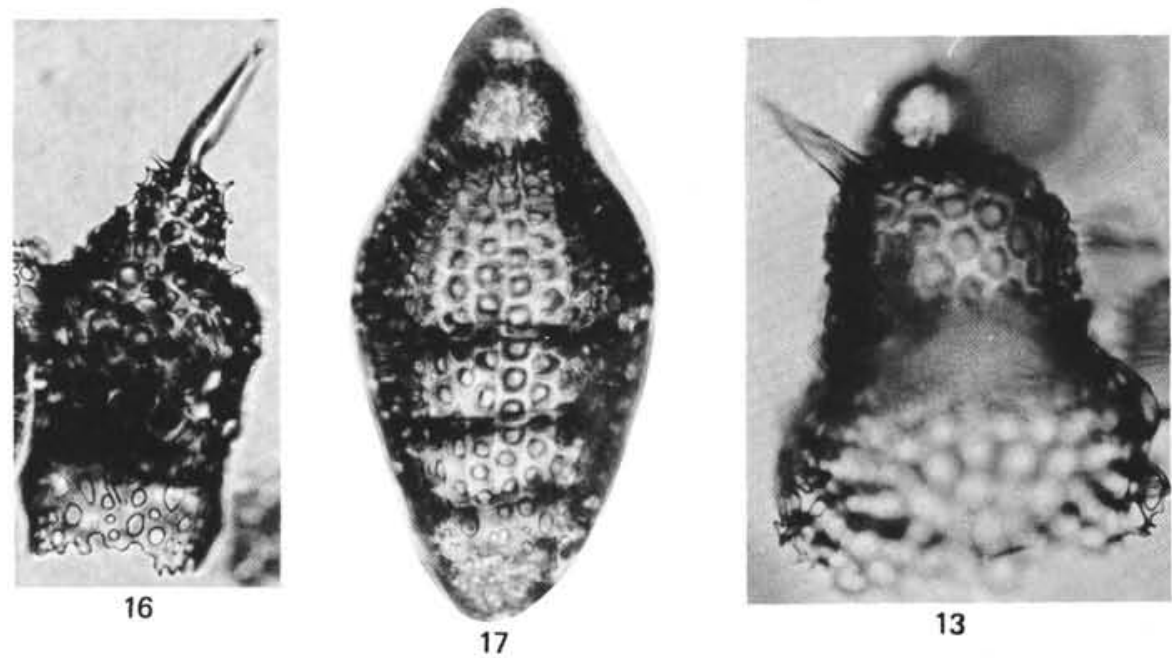

13
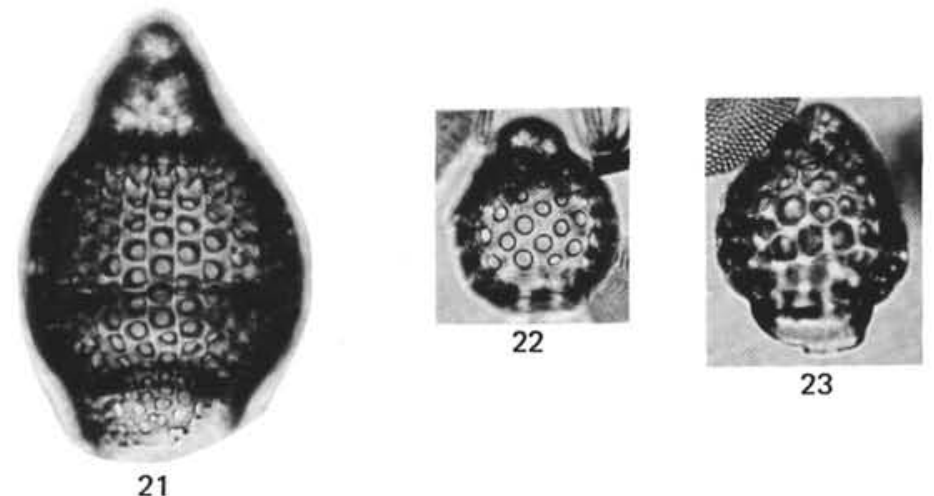


\section{PLATE 17}

Scale bar is $100 \mu \mathrm{m}$

Figures 1-5 Ceratocyrtis mashae n. sp.

1, 2. 338-11-3, 135-137 cm.

3. $338-12-3,145-147 \mathrm{~cm}$.

4, 5. 338-16, CC.

Figures 6-10 Ceratocyrtis robustus n. sp.

6, 7. $338-15-4,130-132 \mathrm{~cm}$.

8. $338-17, \mathrm{CC}$.

9,10. 338-19-3, $80-82 \mathrm{~cm}$.

Figures 11-13 Cyrtocapsella eldholmi n. sp.

$338-12-2,145-147 \mathrm{~cm}$.

Figures 14-16 Cyrtocapsella sp.

14. $338-10-2,60-62 \mathrm{~cm}$.

$15,16.338-11-3,135-137 \mathrm{~cm}$.

Figures 17, 18 Cyrtocapsella japonica (Nakaseko, 1962).

$338-15-4,130-132 \mathrm{~cm}$.

Figures 19,20 Cyrtocapsella tetrapera Haeckel, 1887. $338-15-4,130-132 \mathrm{~cm}$.

\section{PLATE 18}

Scale bar is $100 \mu \mathrm{m}$

Figure 1 Peripyramis sp.

338-12, CC.

Figures 2-6 Stichocorys sp.

2. $338-12-2,145-147 \mathrm{~cm}$.

3. $338-13-5,125-127 \mathrm{~cm}$.

4, 5. 338-15-2, 145-147 cm.

6. $338-15-4,120-122 \mathrm{~cm}$.

Figures 7-11 Trissospyris sp. A.

7. $338-13-3,145-147 \mathrm{~cm}$.

8, 9. 338-13, CC.

10. $338-15-2,145-147 \mathrm{~cm}$.

11. $338-21-1,100-102 \mathrm{~cm}$.

Figures 12-17 Trissospyris sp. B.

12-14. 338-13, CC.

$15,16.338-14-2,140-142 \mathrm{~cm}$.

17. $338-14$, CC.

Figures 18-21 Ceratocyrtis sp.

$338-15-2,145-147 \mathrm{~cm}$.

Figures 22-27 Gondwanaria japonica (Nakaseko, 1963). $22,23.338-13$, CC.

24-27. $338-15-2,145-147 \mathrm{~cm}$.

(see page 1158) 
PLATE 17
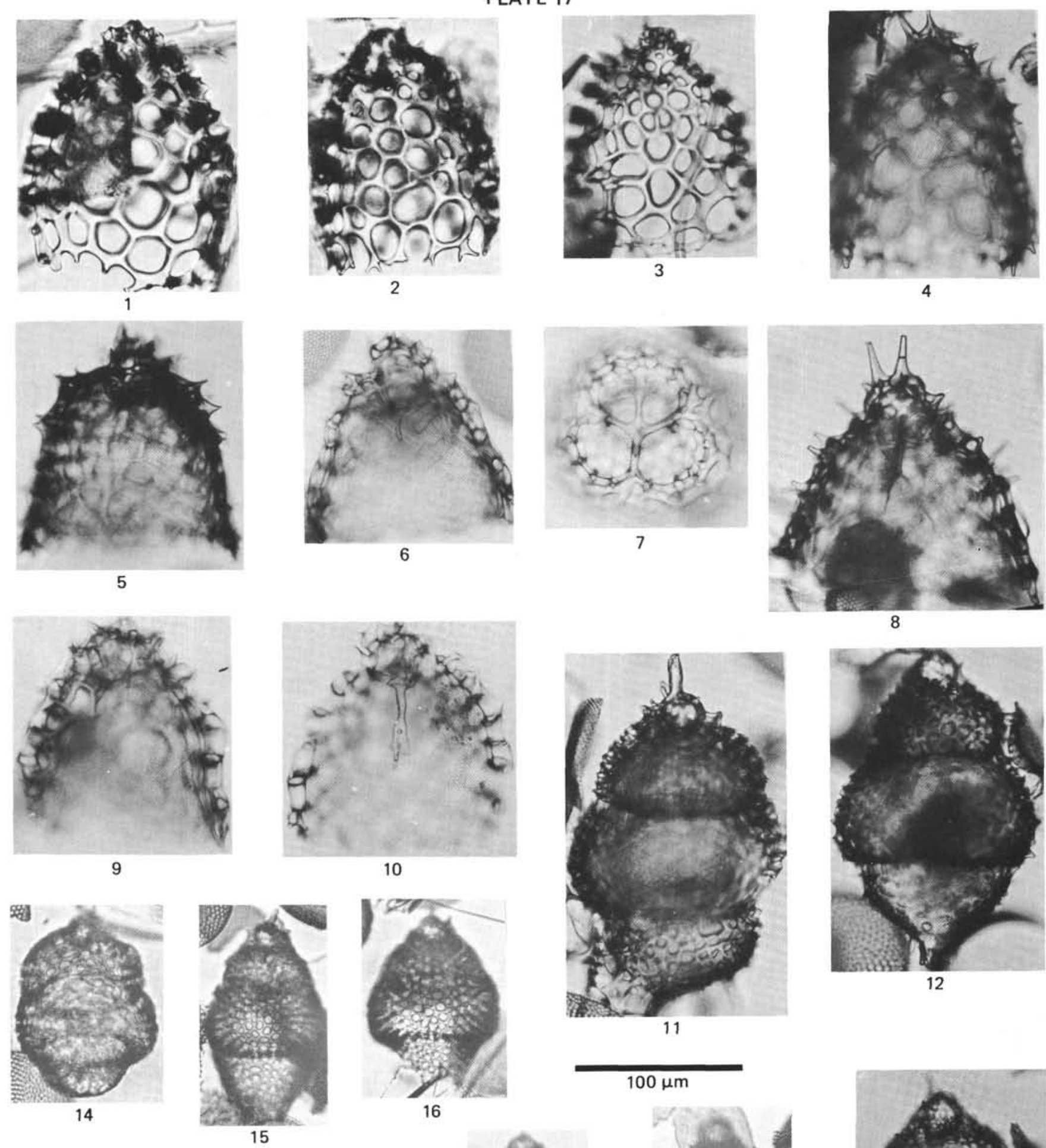

14

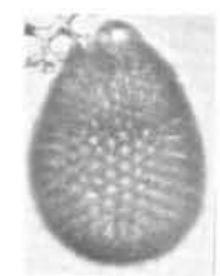

17

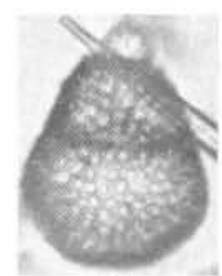

18

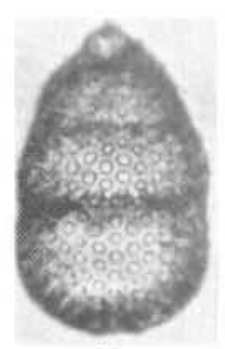

19
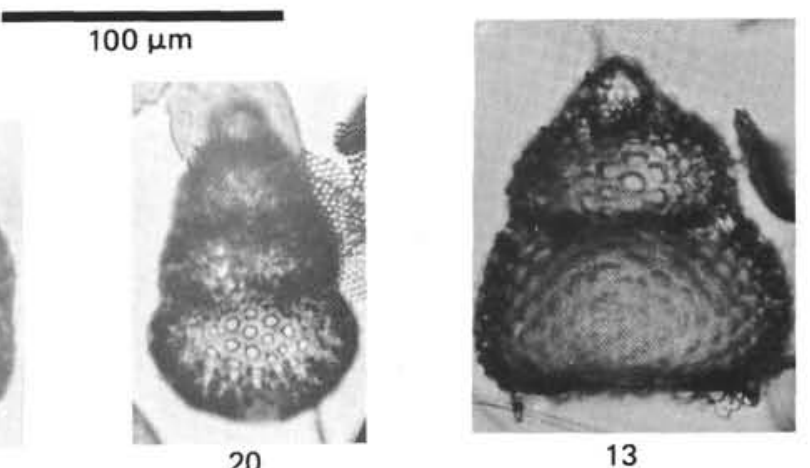
PLATE 18
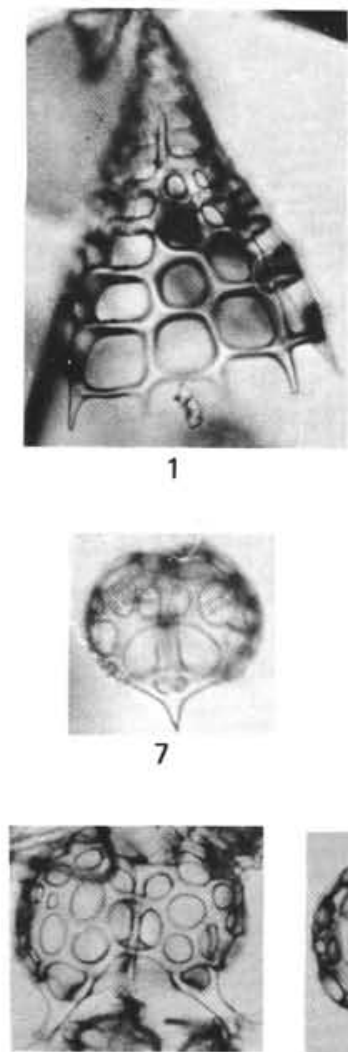

12

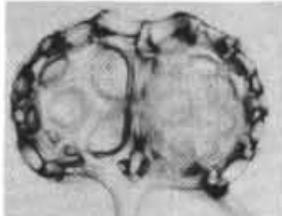

13
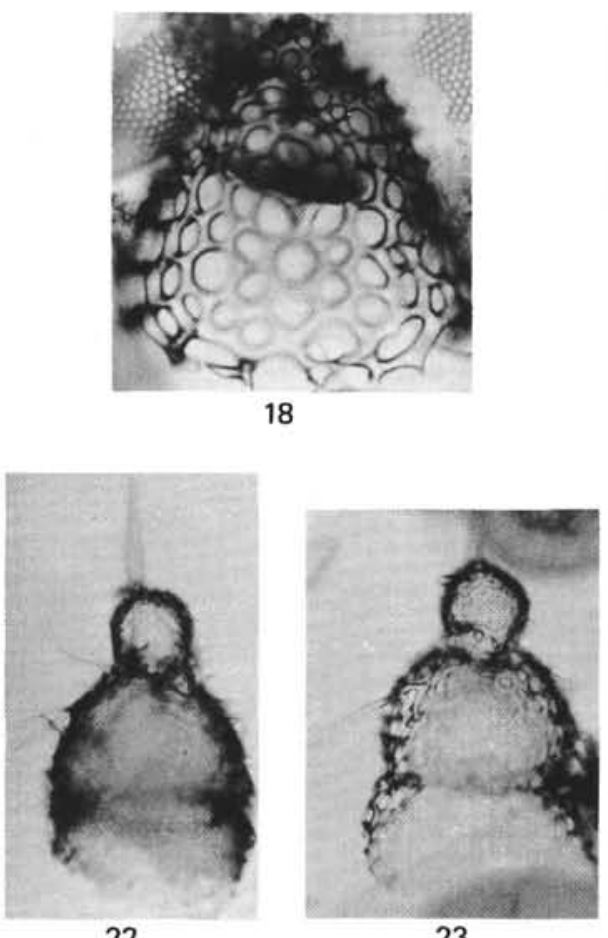

23
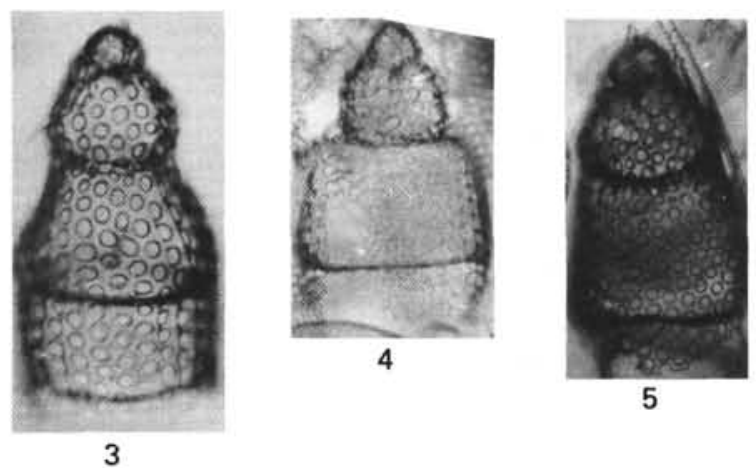

5
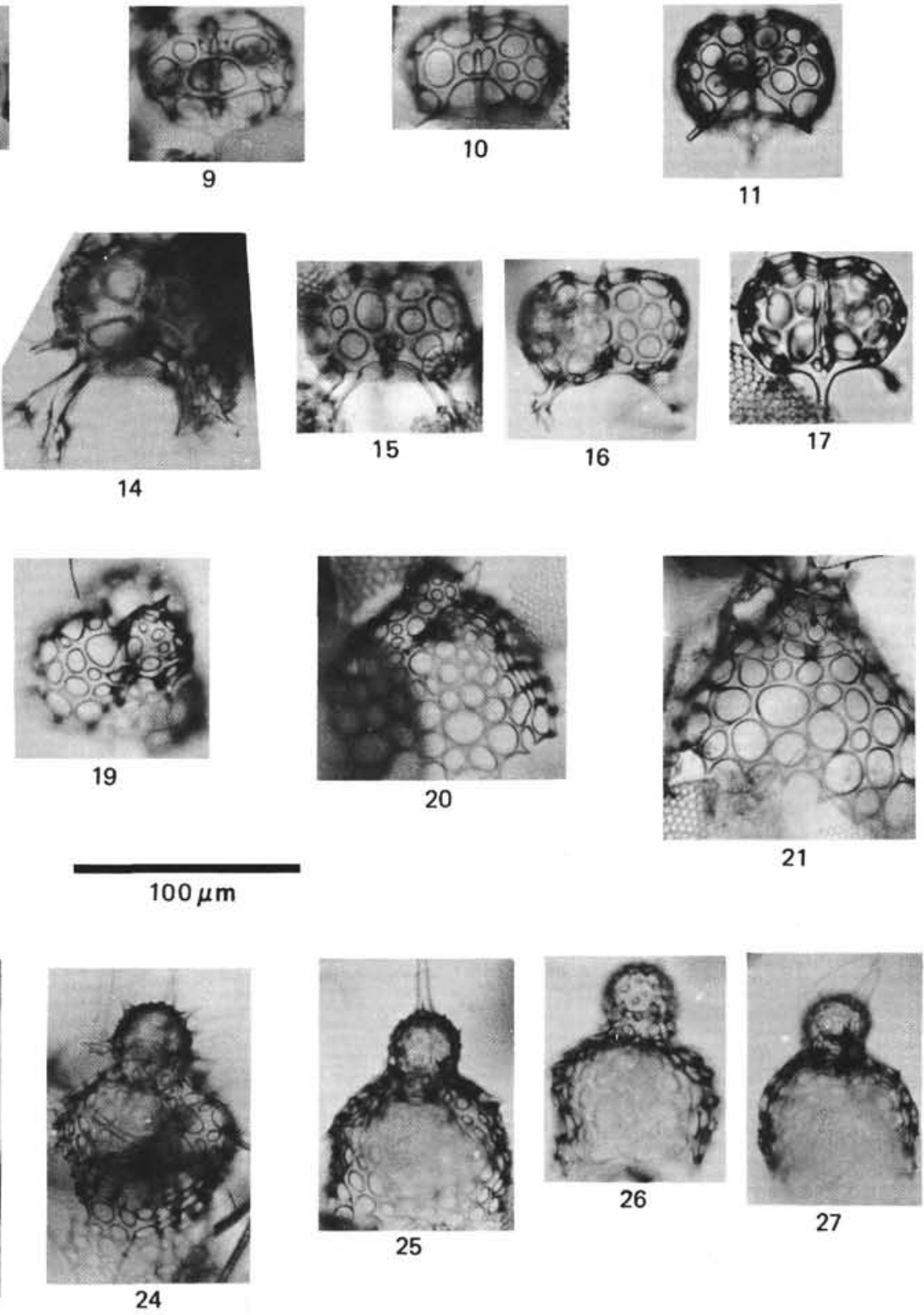

27 


\section{PLATE 19}

Scale bar Figures 6-9 is $0 \mu \mathrm{m}$, Figures $1-4,10-12,100 \mu \mathrm{m}$

Figures 1,

Actinomma sp.

$338-15-4,130-132 \mathrm{~cm}$.

Figures 3,4 Hexalonche sp.

$338-17, \mathrm{CC}$.

Figure $5 \quad$ Hexaconthium $\mathrm{sp}$.

$338-26, \mathrm{CC}$.

Figures 6-9 Velicucullus oddgurneri n. sp.

6, 7. 338-12, CC.

8. $338-11-3,135-137 \mathrm{~cm}$.

9. $338-12-2,145-147 \mathrm{~cm}$.

Figures 10-12 Antarctissa (?) sp. $338-29-3,123-125 \mathrm{~cm}$

(see page 1160)

PLATE 20

Scale bar is $175 \mu \mathrm{m}$

Figure $1 \quad$ Spongodiscus sp.

$338-8-2,120-122 \mathrm{~cm}$.

Figures 2, $3 \quad$ Spongotrochus glacialis Popofsky, 1908

2. $338-8-2,53-55 \mathrm{~cm}$.

3. $338-8-3,45-47 \mathrm{~cm}$.

Figures 4-6 Phorticium sp.

4. 338-19, CC

5, 6. $338-21, \mathrm{CC}$

Figure 7 Actinomma sp.

$338-10$, CC.

Figures 8, $9 \quad$ Actinomma holtedahli $\mathrm{n}$. sp.

8. $338-15-2,145-147 \mathrm{~cm}$.

9. $338-15-4,130-132 \mathrm{~cm}$.

Figures 10,11 Phacodiscus testatus Kozlova, 1966.

$338-28$, CC

Figures 12,13 Heliodiscus sp. aff. H. hexasteriscus (?) Clark and Campbell, 1942.

(see page 1161) 
K. R. BJ $\phi R K L U N D$

PLATE 19
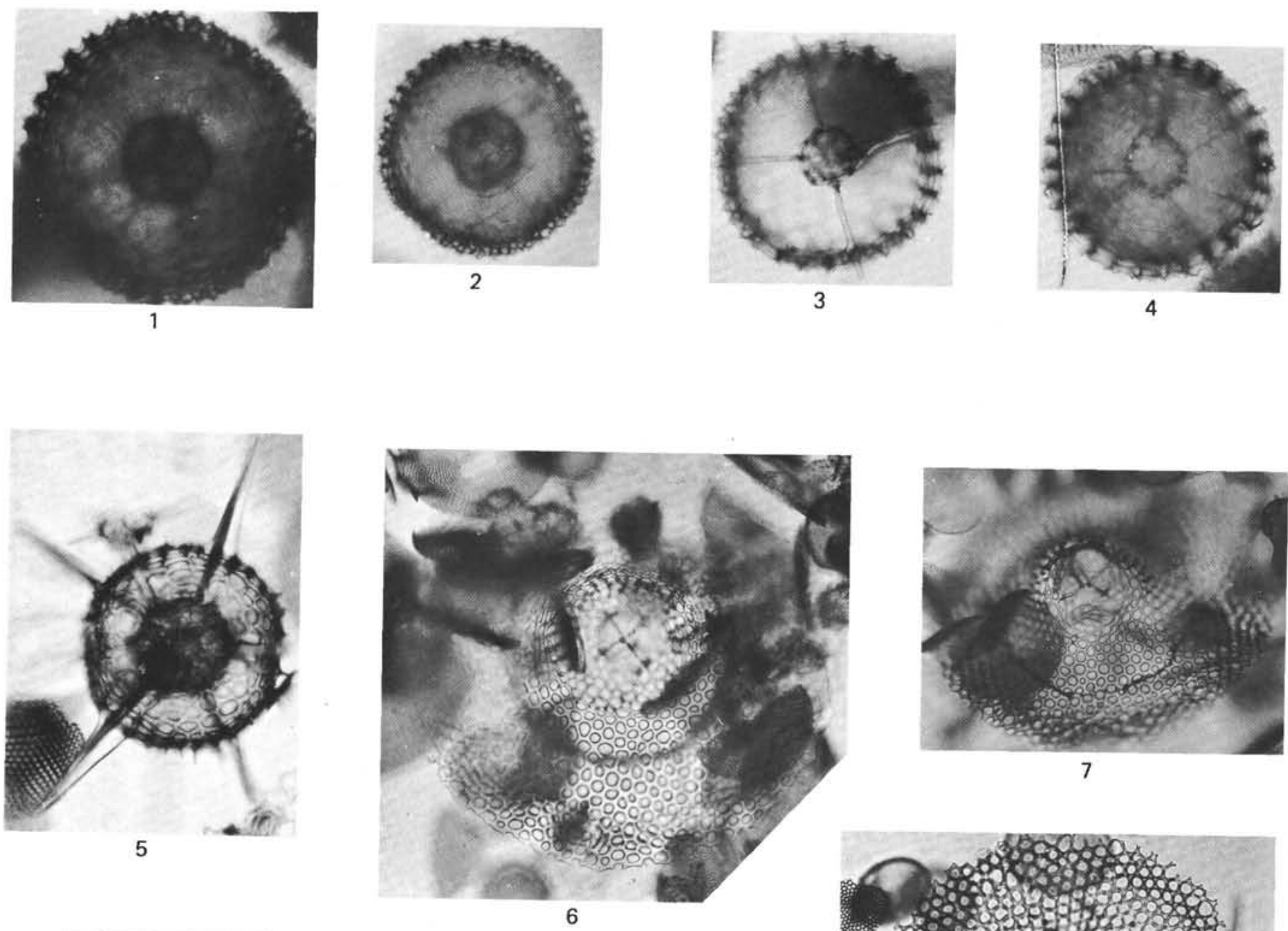

7

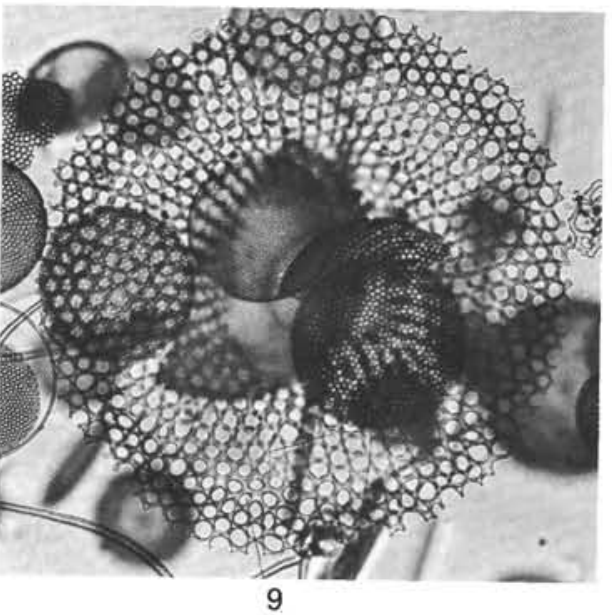

Figures $1-5,10-12=100,6-9=50 \mu \mathrm{m}$

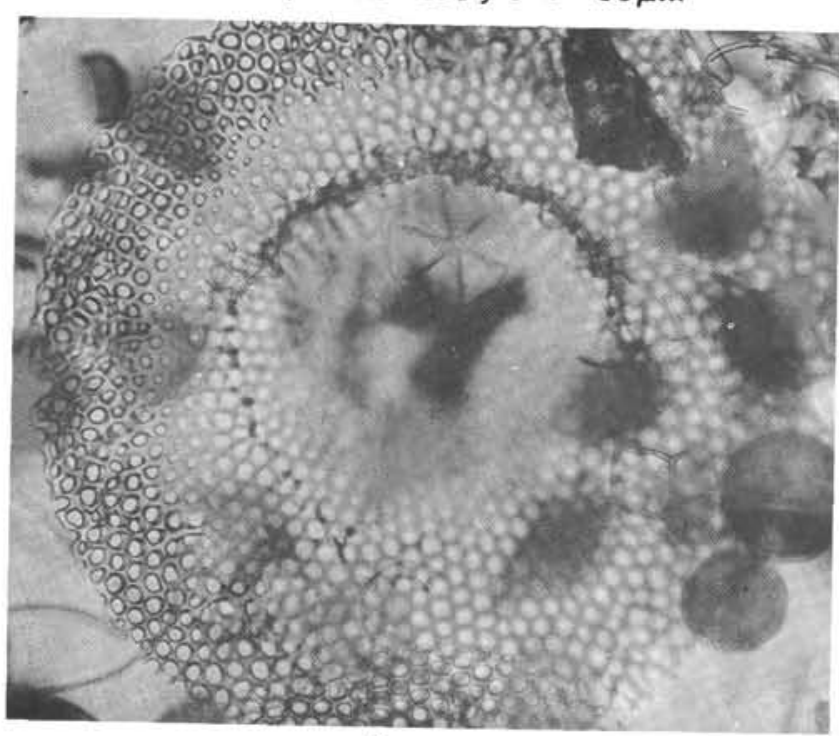

8

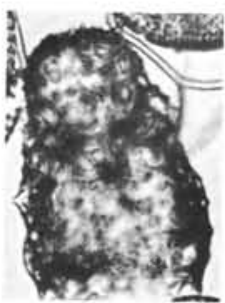

10

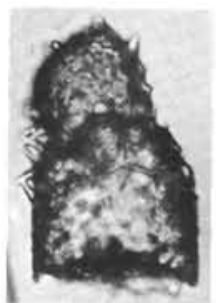

11

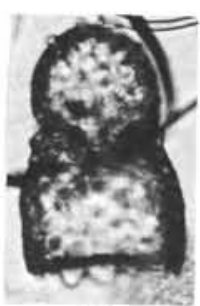

12 


\section{PLATE 20}
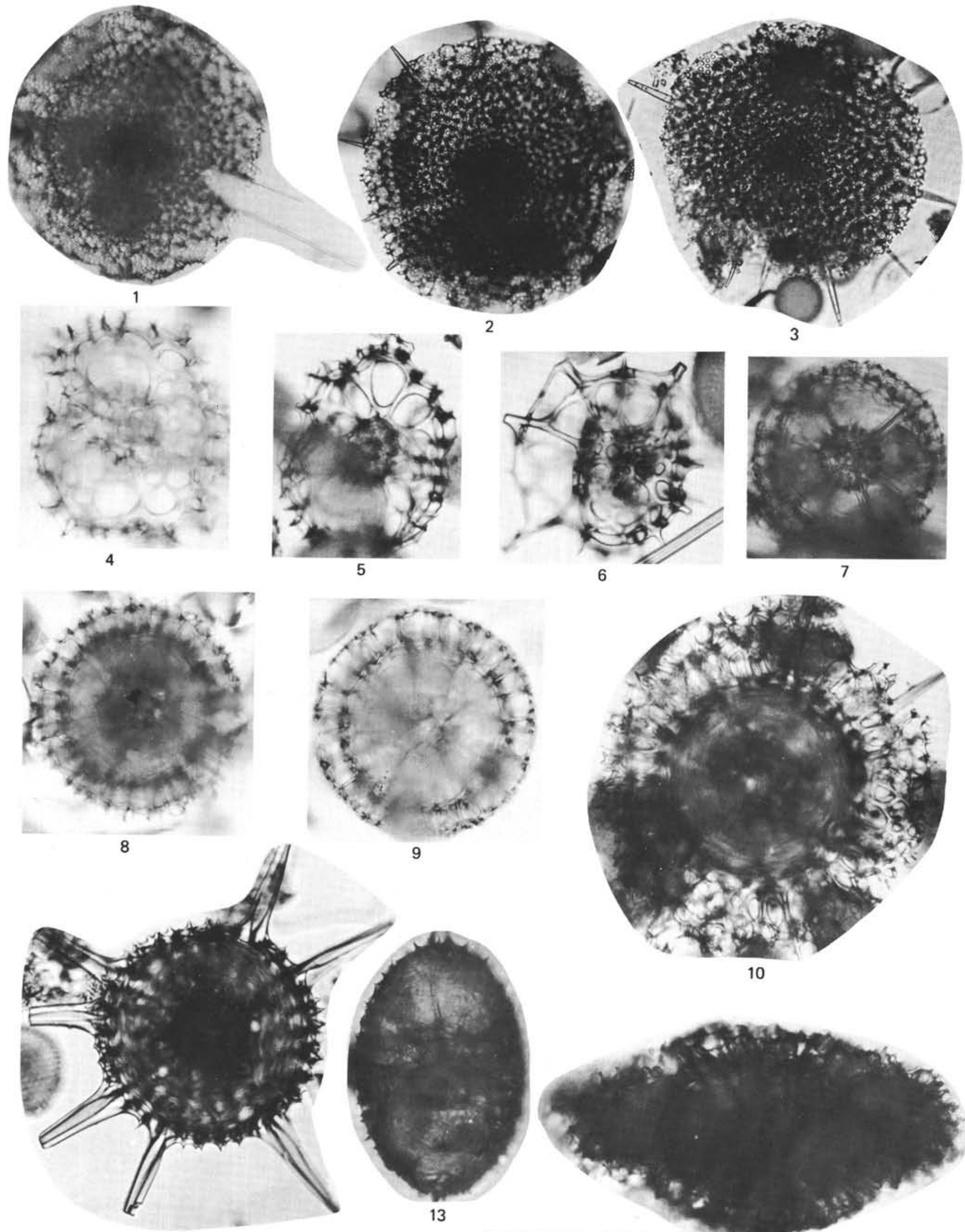

12
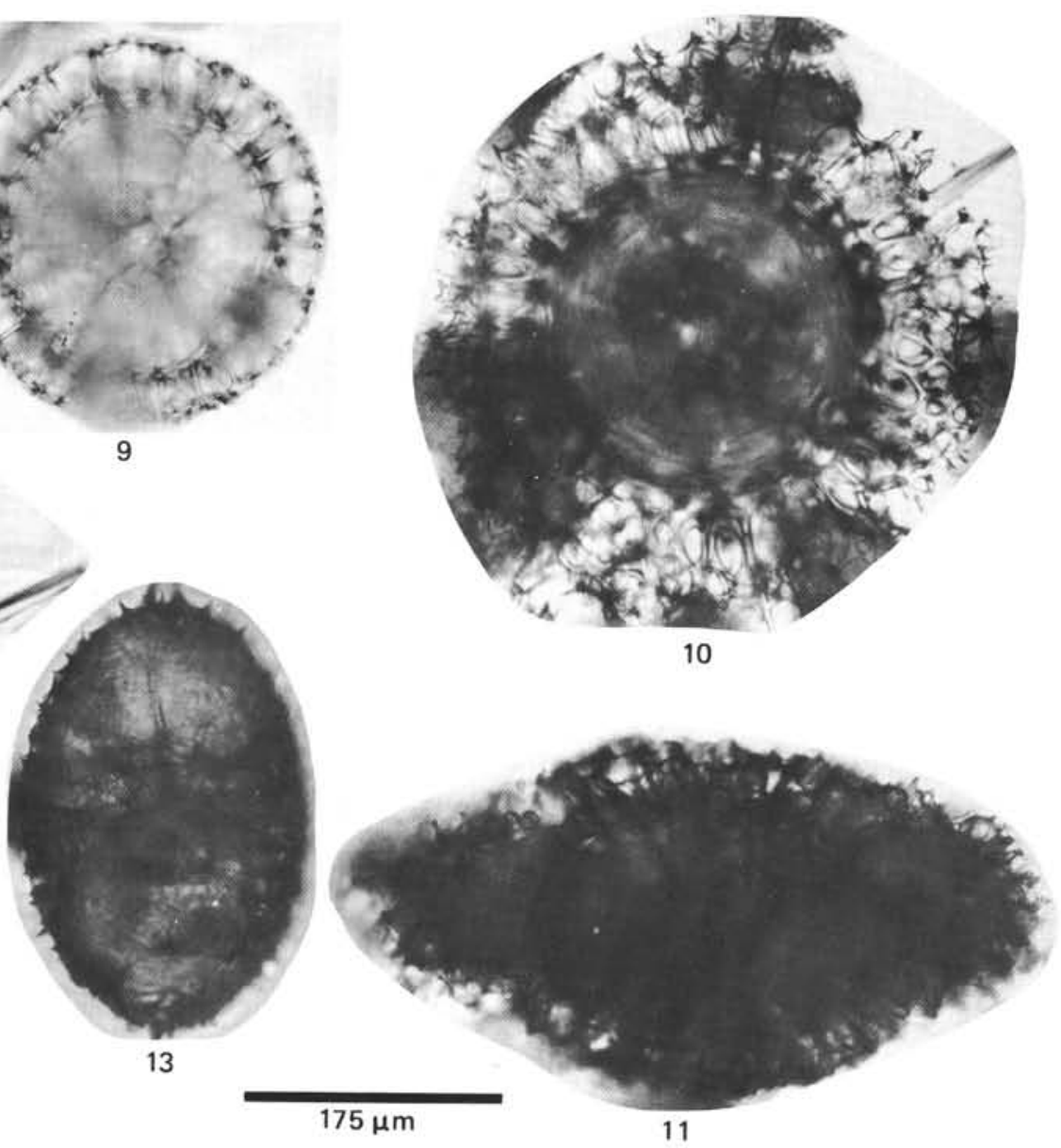
PLATE 21

Scale bar is $100 \mu \mathrm{m}$

Figures 1-3 Calocyclas talwanii Bj申rklund and Kellogg, 1972.

1. 338-29-1, $148-150 \mathrm{~cm}$.

2. $340-8$, CC.

3. $340-10, \mathrm{CC}$.

Figures 4-7 Calocyclas extensa (Clark and Campbell, 1942).

4. $340-8, \mathrm{CC}$.

5-7. $343-5, \mathrm{CC}$

Figures 8-10 Calocyclas sp.

343-5, CC.

Figure 11 Lophocorys norvegiensis Bj申rklund and Kellogg, 1972.

$338-26$, CC.

Figures 12-15 Lophocorys sp.

12. $338-26, \mathrm{CC}$.

13-15. 340-8, CC.

Figures 16,17 Lophocorys biaurita (Ehrenberg, 1875).

339-8-2, 80-82 cm. 


\section{PLATE 21}
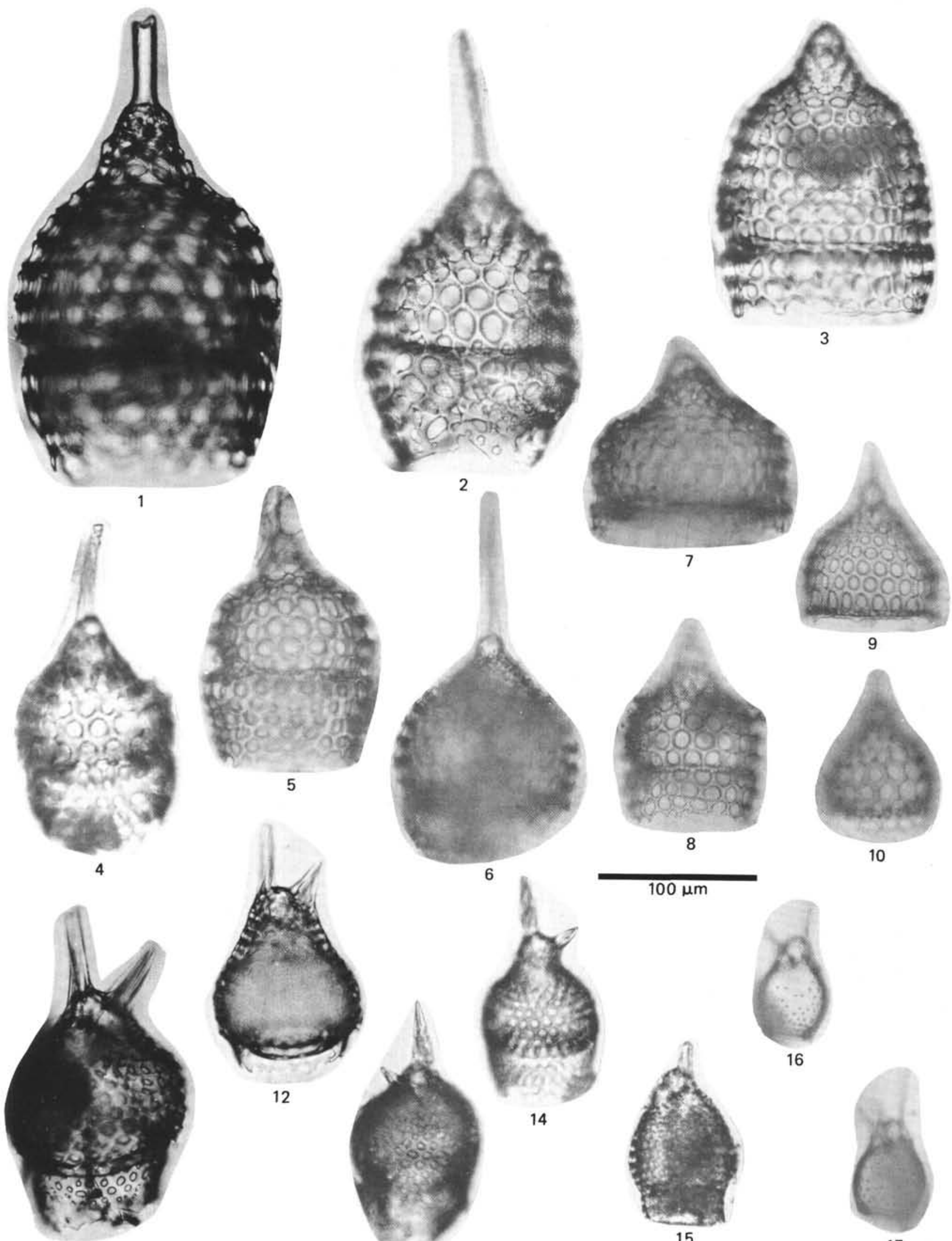

11
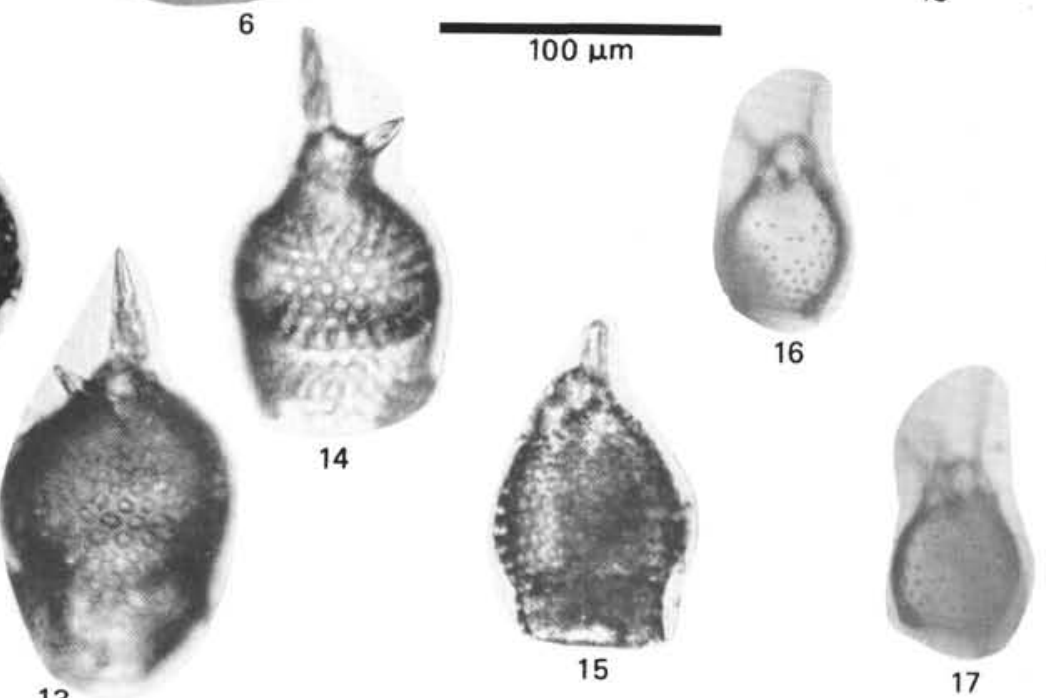
PLATE 22

Scale bar is $100 \mu \mathrm{m}$

Figures 1, 2 Calocyclas sp.

338-26-3, 67-69 cm.

Figures 3, $4 \quad$ Calocyclas sp.

339-9, CC.

Figure $5 \quad$ Calocyclas sp.

339-11, CC.

Figures 6-9 Spongomelissa sp. sensu Chen, 1975.

6. $338-21-1,100-102 \mathrm{~cm}$.

7, 8. 338-21, CC.

9. $338-26-3,67-69 \mathrm{~cm}$.

Figure $10 \quad$ Tripilidium (?) clavipes advena Clark and Campbell, 1942.

$339-12-2,110-112 \mathrm{~cm}$.

Figures 11, 12 Nassellaria indet. 338-19, CC.

Figures 13, 14 Peripyramis magnifica Clark and Campbell, 1942. $339-12-2,110-112 \mathrm{~cm}$.

Figures 15-17 Theocalyptra tetracantha Bjфrklund and Kellogg, 1972.

15, 16. 338-27, CC.

17. $339-12-2,110-112 \mathrm{~cm}$. 
PLATE 22
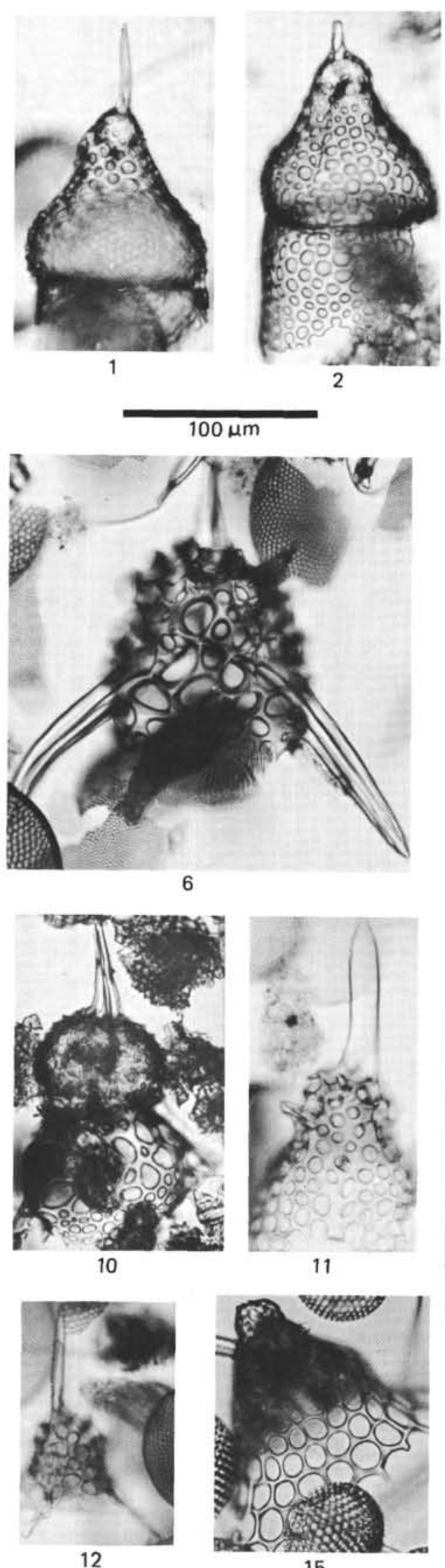

15

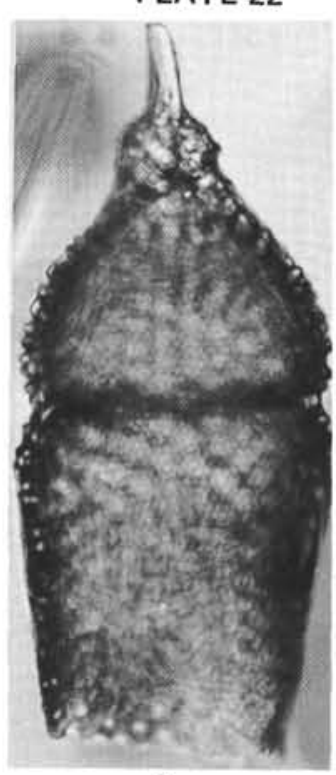

3
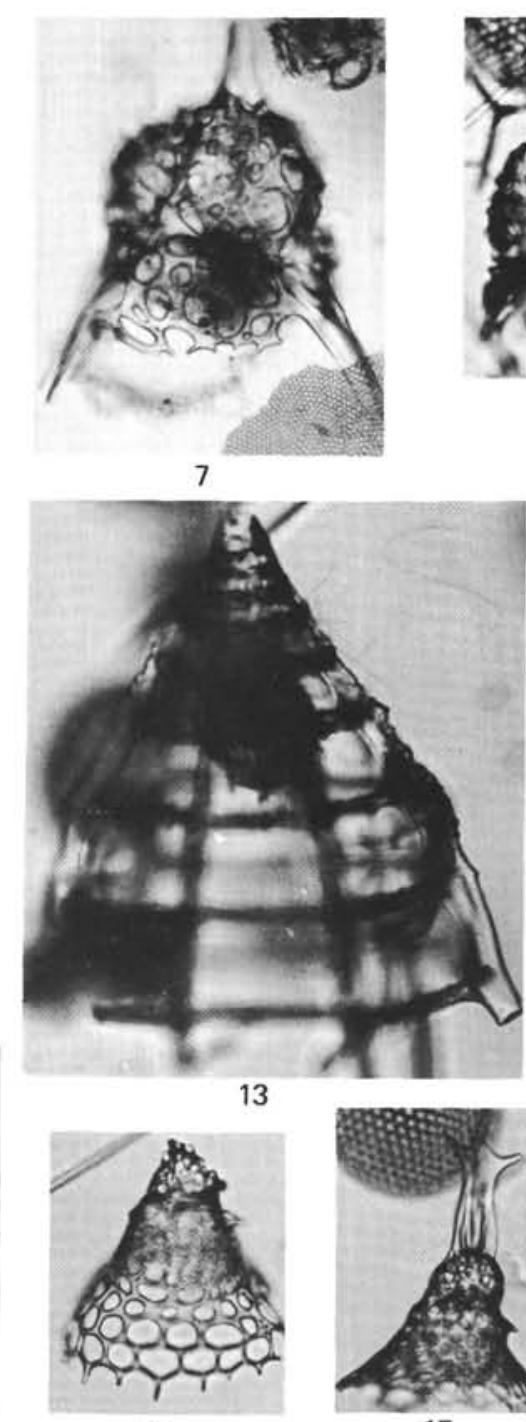

16
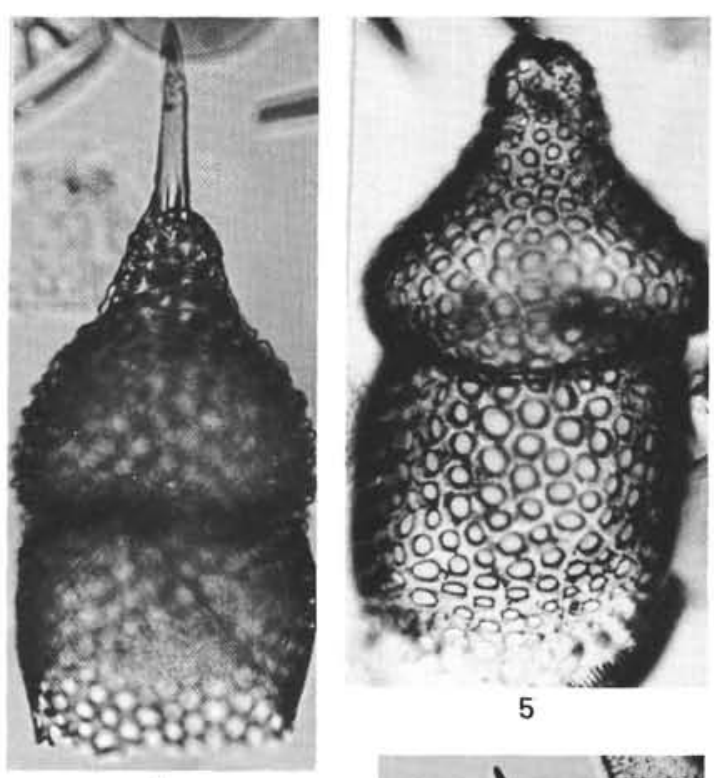

5

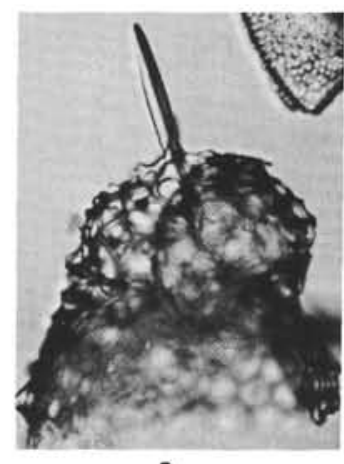

9

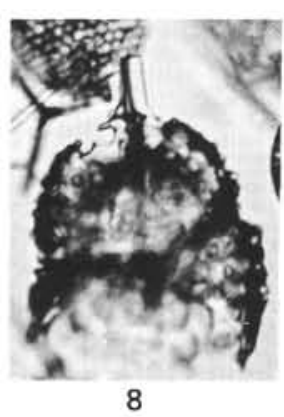

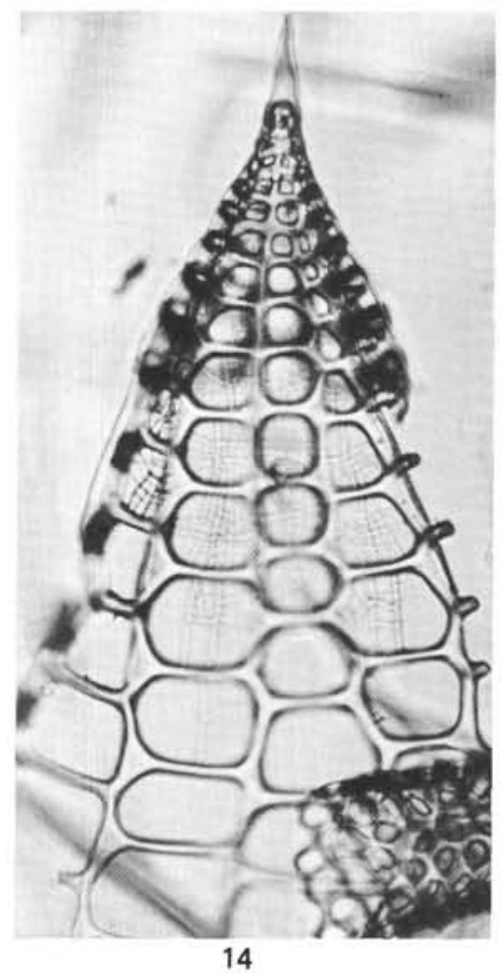


PLATE 23

Scale bar is $100 \mu \mathrm{m}$

Figures 1-3 Lithomitra sp.

$338-26-3,67-69 \mathrm{~cm}$.

Figures 4-6 Lithomitra sp.

$339-8-2,110-112 \mathrm{~cm}$.

Figures 7-14 Botryostrobus joides Petrushevskaya, 1975.

7, 8. 339-8-3, $80-82 \mathrm{~cm}$.

9-13. 339-9, CC.

14. $338-26-3,67-69 \mathrm{~cm}$.

Figures 15-21 Artostrobus quadriporus n. sp. 339-11, CC.

Figure $22 \quad$ Ceratospyris sp.

$339-8-3,80-82 \mathrm{~cm}$.

Figures 23, 24 Cornutella sp. aff. C. californica Clark and Campbell, 1942.

339-11, CC.

Figures 25-27 Gen. et sp. indet.

339-11, CC.

\section{PLATE 24}

Scale bar Figures 1-5 is $100 \mu \mathrm{m}$; Figure 6, $50 \mu \mathrm{m}$; Figures 7-9, $150 \mu \mathrm{m}$

Figures 1,2 Gen. and sp. indet.

339-9, CC.

Figures 3-5 Pterocyrtidium sp. aff. $P$. reschetnjakae sensu Petrushevskaya, 1971.

339-11, CC.

Figures 6-9 Arachnocalpis tumulosa Kozlova, 1966.

343-5, CC.

Figures 10, 11 Lychnocanium (?) sp.

339-11, CC. 
PLATE 23
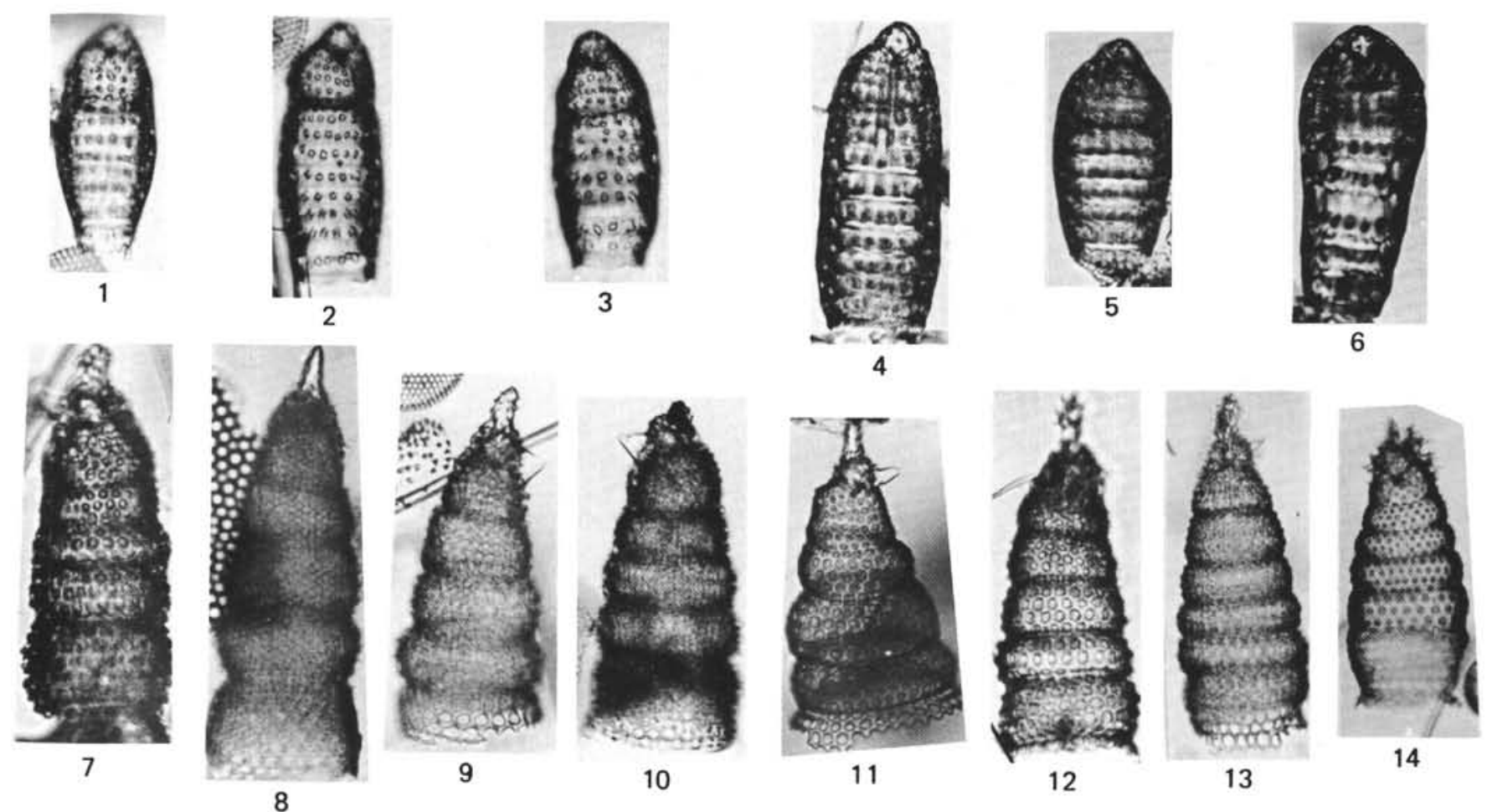

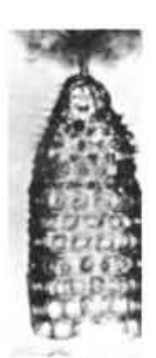

15

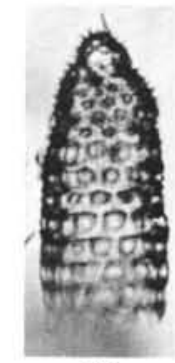

16

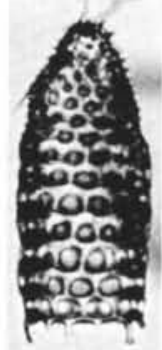

17

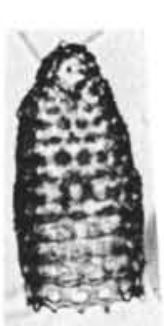

18

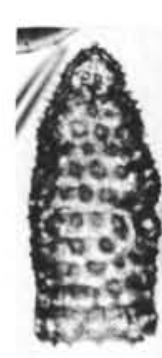

19

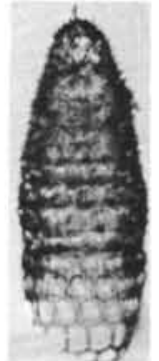

20

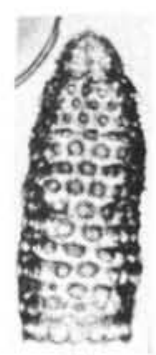

21

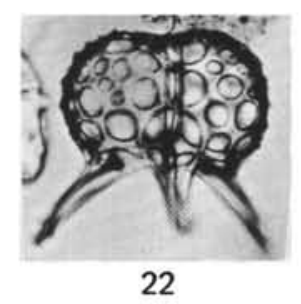

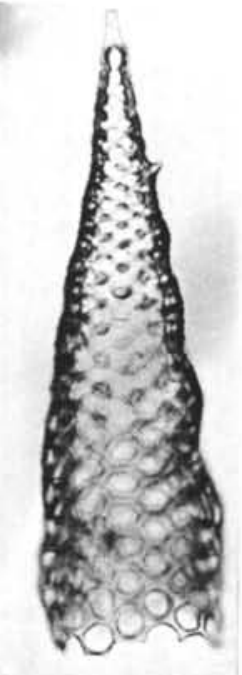

23
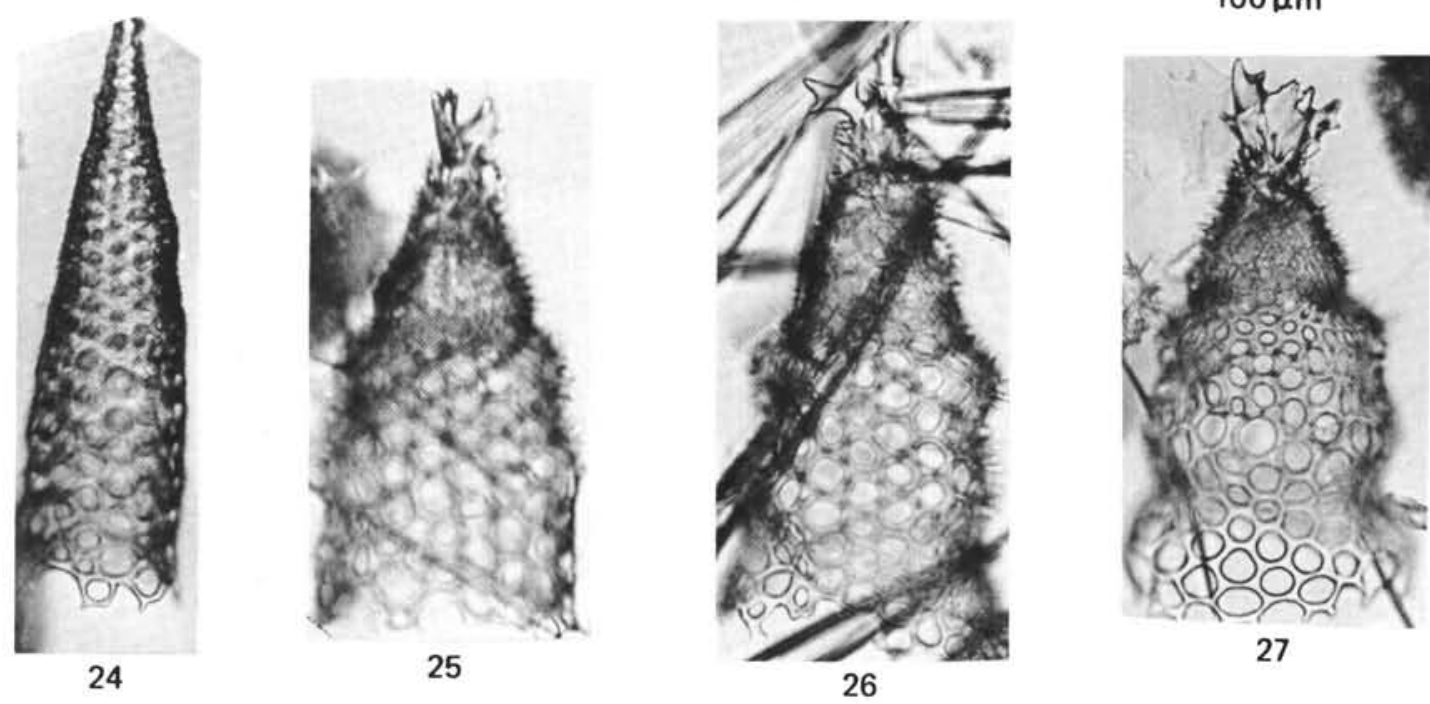
PLATE 24
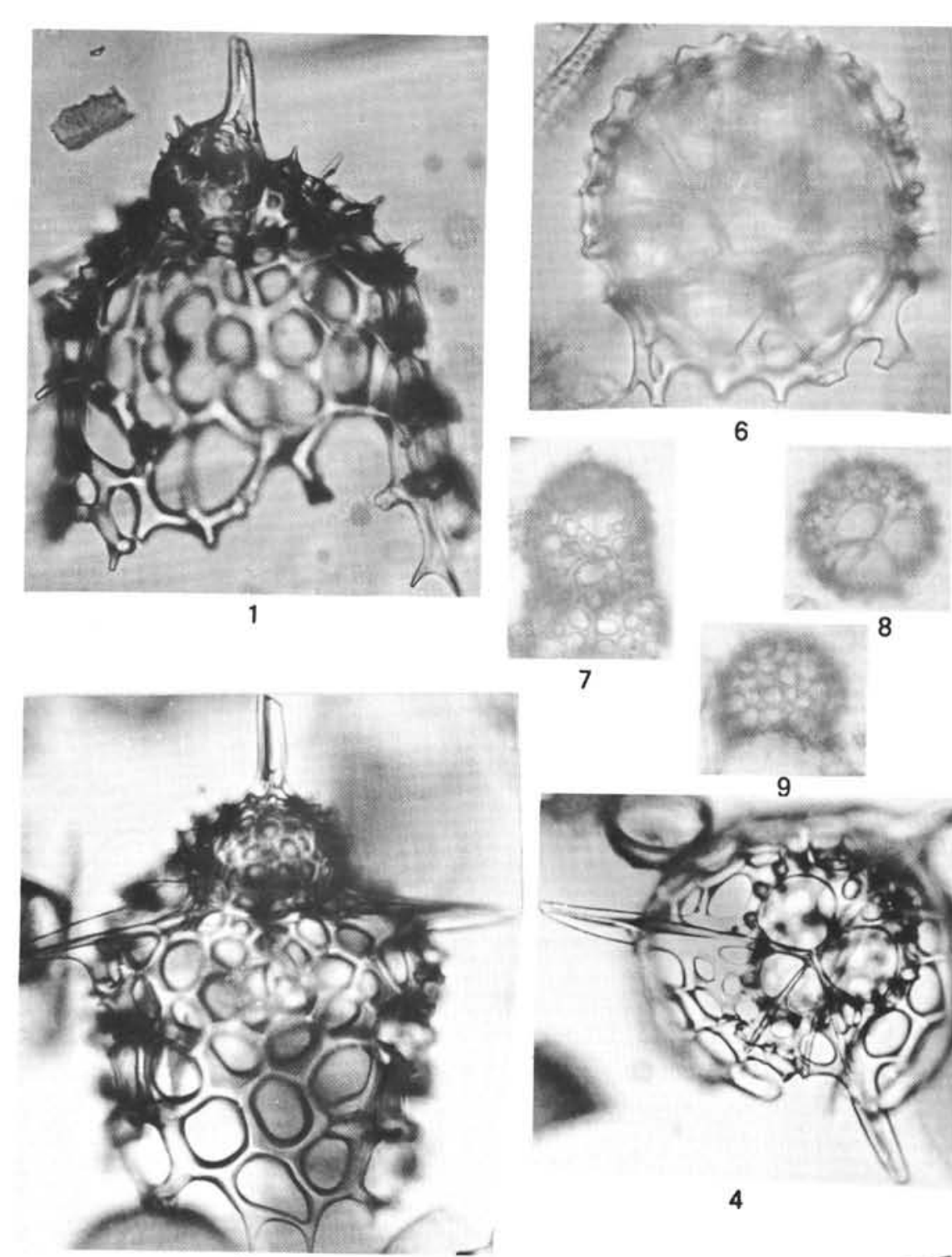

3

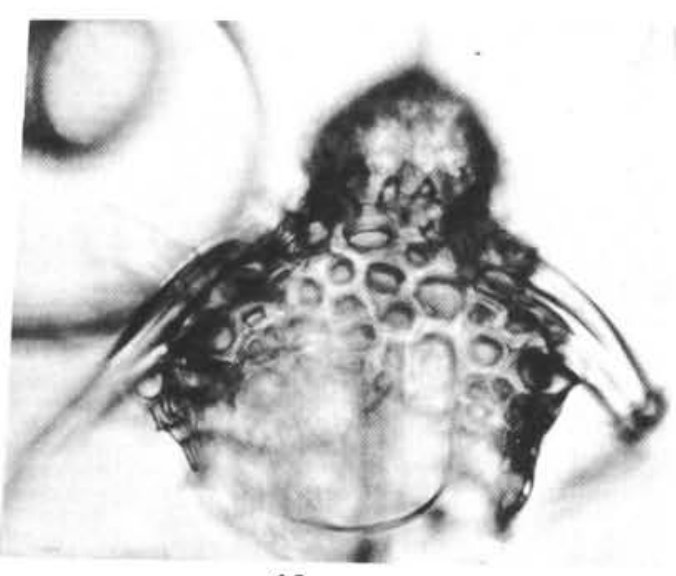

10
6
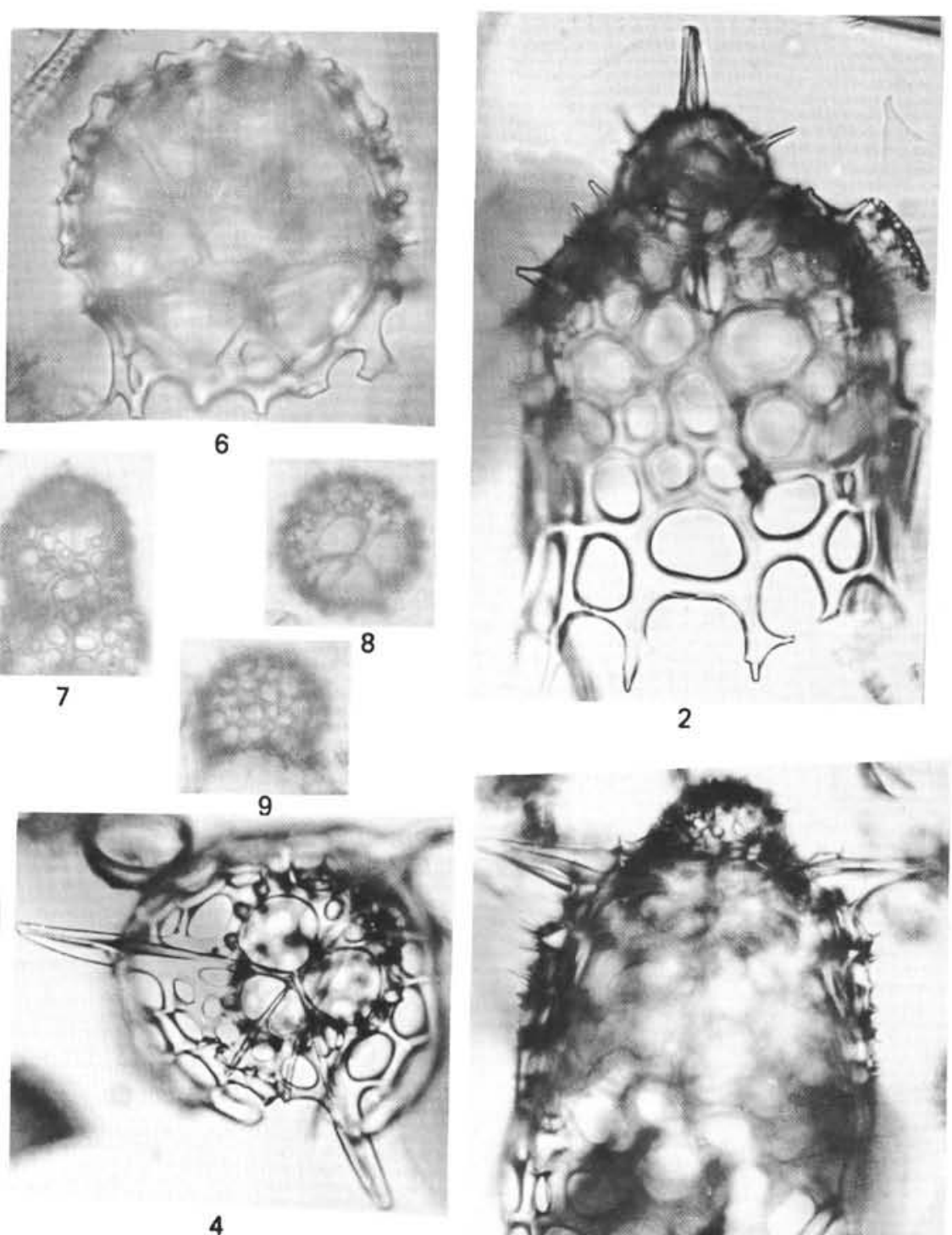

4

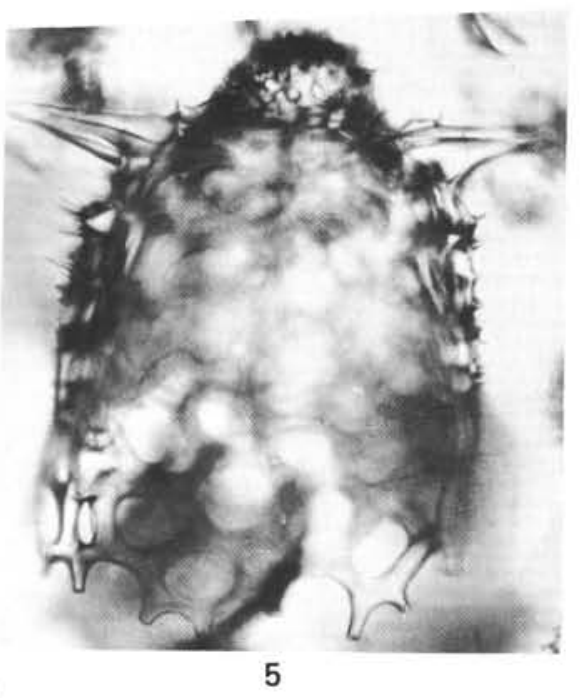

$100 \mu \mathrm{m}$

Figures $1-5,10,11=100 \mu \mathrm{m}$

Figure $6=50 \mu \mathrm{m}$

Figures $7-9=150 \mu \mathrm{m}$ 